\title{
(1)
}

UNIVERSIDAD PERUANA DE CIENCIAS APLICADAS

FACULTAD DE PSICOLOGIA

CARRERA DE PSICOLOGIA

\section{Elección de pareja : Un estudio cualitativo sobre paciente en psicoterapia psicoanalítica}

\author{
TESIS \\ Para optar el Titulo Profesional en Psicología
}

\begin{abstract}
AUTORES
Andrés Anteparra Venturo (0000-0001-5884-8029)

Romina Dasso Zumarán (0000-0002-7116-3953)

ASESOR DE TESIS

Olinda Serrano de Dreifuss (0000-0001-6235-3627)
\end{abstract}

Lima, 12 de Noviembre de 2018 


\section{RESUMEN}

La elección de pareja es un proceso natural que incluye tanto aspectos conscientes como inconscientes. Por ello, la presente investigación explora el proceso de esta elección a partir del insight, en participantes que hayan sido parte de un proceso de psicoterapía psicoanalítica de al menos un año de continuidad. Se trabajó con 8 informantes tanto heterosexuales como homosexuales, entre 24-27 años, egresados de psicología clínica que permitieron profundizar respecto a su elección de pareja en función a su historia de vida. Adicionalmente, los resultados fueron analizados en función a la teoría psicoanlítica que plantea una relación entre el primer objeto de amor elegido y las elecciones futuras. Con ello, se pretende entender la elección de pareja desde una mirada actual rompiendo los esquemas sociales impuestos.

Palabras Claves: Elección de pareja, Inconsciente, insight, relaciones objetales. 


\begin{abstract}
Choosing a partner is a natural process that includes both conscious and unconscious aspects. Therefore, the following research aims to understand the selection process using insights, of participants who have been exposed to psychodynamic oriented therapy for at least one continuous year. We worked with 8 informants both heterosexual and homosexual, aged 24-27 years, graduated in clinical psychology which allowed them to deepen their choice of partners according to their life history. In addition, the results were analyzed according to the psychoanalytic theory that proposes a relationship between the first chosen love object and future elections. With this, it is intended to understand the selection process from a current view breaking the social schemes imposed.
\end{abstract}

Keywords: Choice of couple, unconscious, insight, object relations. 


\section{TABLA DE CONTENIDO}

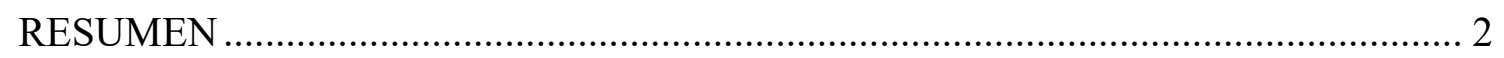

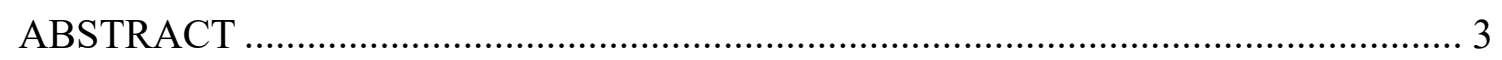

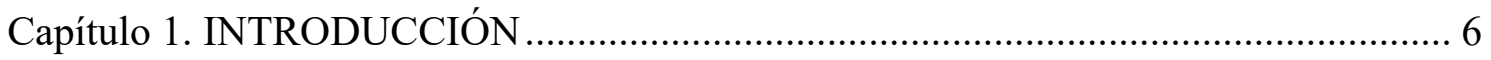

Capítulo 2. MARCO TEÓRICO …........................................................................... 7

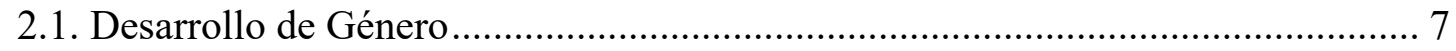

2.2. Visión psicodinámica de la elección de pareja................................................... 9

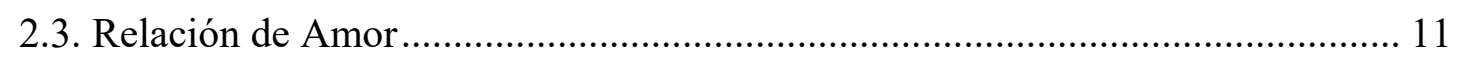

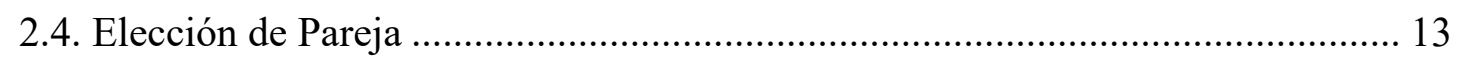

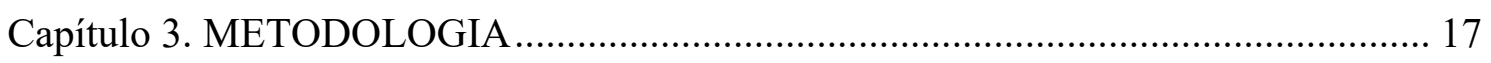

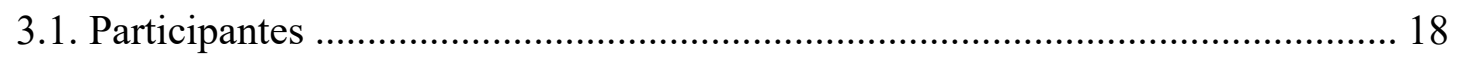

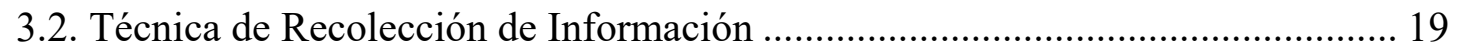

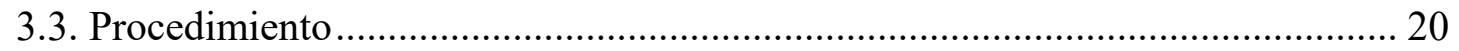

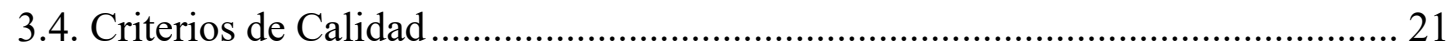

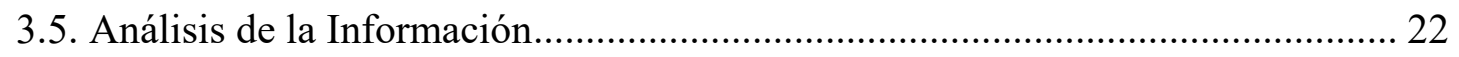

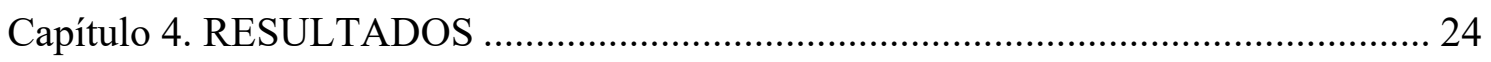

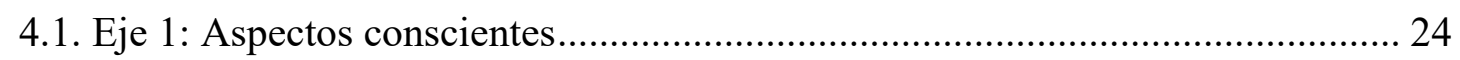

4.2. Eje 2: Aspectos inconscientes...................................................................... 26

4.3. Eje 3: Construcción personal de la noción frente a la elección de pareja ............ 31

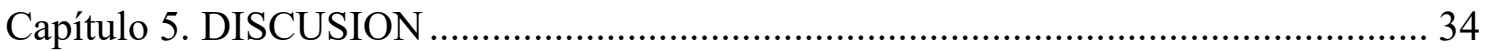

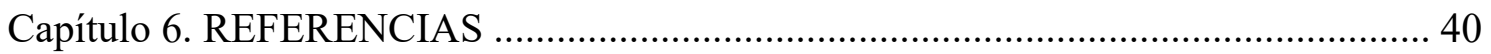

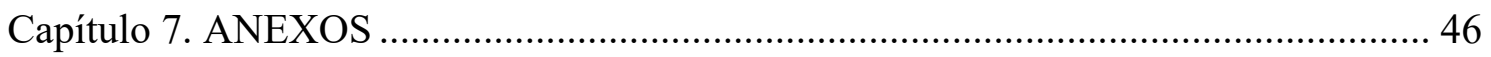




\section{INDICE DE TABLAS}

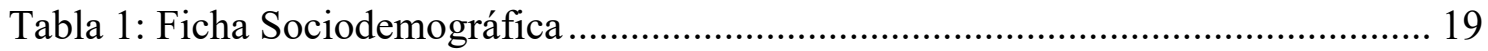

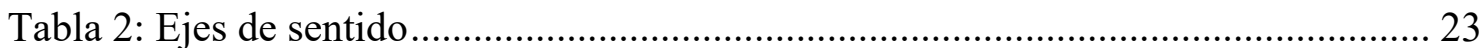




\section{Capítulo 1. INTRODUCCIÓN}

La elección de pareja genera diversos cuestionamientos respecto a qué factores genéticos, culturales, económicos, sociales y/o personales influenciaron en la elección de este otro (Casullo, 2003). A esta consolidación entre dos sujetos se le denomina vínculo, entendido como la unión de una persona con el otro (Guerra, 2003). Esta relación de pareja, como cualquier vínculo, tiene como base las experiencias relacionales que se han ido desarrollando en cada persona desde la infancia (Castillo, 2009). Willi (2004), considera que para que una persona alcance su potencial personal necesita de otros seres humanos, en especial, de una pareja. Es por ello que, todo sujeto tiene el deseo de poder elegir con quien establecer un vínculo de pareja. Las razones que se dan frente a esta elección siguen generando diversas interrogantes y cuestionamientos, por lo que continúan siendo fuente de estudio actualmente.

De esta manera, y debido a la singularidad de cada individuo, la elección de pareja es particular y determinada por distintos factores que se han ido desarrollando desde la niñez. Dado ello, distintas teorías psicoanalíticas postulan que la construcción de pareja que se da entre dos personas, no es sino un modelo de relación que el individuo anhela recrear con su infancia (Klein, 1994). En ese sentido, la elección de este otro podría entenderse como la incorporación inconsciente de afectos y vivencias interpersonales que marcaron dicha elección (García, Garrido \& Rodríguez, 1993). 


\section{Capítulo 2. MARCO TEÓRICO}

\subsection{Desarrollo de Género}

El mundo actual ha dado lugar a una nueva concepción con respecto a las relaciones de pareja, en donde se espera que se respeten los valores como la igualdad, libertad y derechos individuales de esta elección. Por el contrario, diferentes estudios mencionan que los modelos culturales imponen modos de relación entre hombres y mujeres, limitando así las posibilidades de tener una elección de pareja libre y sin temor (Verdú, 2013). Por ello, consideramos que los roles en la identidad de género son una determinante para la elección de pareja, en donde la orientación frente a esta elección expresa la preferencia del sujeto en relación al sexo del objeto de amor elegido (Green, 1975).

De esta manera, desde una perspectiva dinámica, el género estaría relacionado a diversas características tales como los pensamientos, sentimientos, creencias, fantasías, y habilidades relacionadas con patrones de cortejo y apareamiento, así como en el modo de crianza a lo largo del tiempo (Meyer, 1980, como se citó en Tyson, 1990). Butler, por su parte, lo define como el mecanismo a través del cual se producen y naturalizan las nociones de lo masculino y lo femenino (Butler, 2006). Sin embargo, cuando hablamos de identidad de género, la entendemos como aquella lucha interna consciente o no - que muestra una construcción propia, y por tanto permite la resignificación de uno mismo a partir de nuevas preguntas, condiciones o situaciones que alteran la posición de la sociedad (Cuevas, 2013). Asimismo, consideramos que comprender el complejo de Edipo permite graficar el inicio tanto de nuestra identidad, como nuestros roles de género (Hall, 2003).

Freud (1923) expone el complejo de Edipo como un proceso central del período sexual de la primera infancia, el cual es vivenciado de manera individual para cada individuo. Laplanche (1996), describe este complejo como un conjunto organizado de deseos amorosos y hostiles que el niño experimenta hacia sus padres. De forma positiva, se presenta como en la historia de Edipo Rey, en donde existe un deseo de muerte del rival que es el personaje del mismo sexo y deseo sexual hacia el personaje del sexo 
opuesto. Y por el contrario, de forma negativa, existe un amor hacia el progenitor del mismo sexo, odio y celos hacia el progenitor del sexo opuesto.

En las niñas, implica tomar a su padre como objeto de amor y generar distintas fantasías respecto la figura paterna, sustituyendo a la madre al verse ella misma como objeto de amor del padre. Al generarse esto, es evidente que la niña está dando un paso a su orientación heterosexual (Tyson, 1990). Esto la llevará, a ver a la madre con decepción o rechazo, y a tomar a la figura paterna como objeto de amor. Sin embargo, cuando el Edipo se resuelve de manera positiva, el temor a la pérdida del amor de la madre, motiva a la niña a reprimir los deseos edípicos libidinales hacia su padre. De esta forma, se mantienen las relaciones afectuosas de ambos padres. Es importante mencionar que la identidad respecto a los roles de género se vuelve más elaborada durante la latencia, pues tanto el niño como la niña evidencian aquellos modelos mentales que han sido instaurados en base a las experiencias de sí mismos y de los objetos, de los roles ejercidos de los padres y del contexto sociocultural (Sandler y Sandler 1978). Es por ello que durante esta etapa, las niñas juegan al rol de ser madres, al cuidado de la casa, de los supuestos hijos, a ser mujeres que se desenvuelven en roles importantes, con distintos niveles de conciencia, pero que surge una identificación con el rol de género, el cual comienza a desarrollarse en base a los comportamientos sociales aprendidos, y con los cuales logra identificarse además de su propia madre (Tyson, 1990). De esta manera, la identidad respecto al rol de género se construye a raíz de la interacción consciente e inconsciente con otras personas.

Sin embargo, no es hasta la adolescencia donde aparece el interés romántico propiamente dicho (Tyson, 1990). Esta etapa se ha definido como un proceso de transición entre la infancia y la vida adulta (Coleman \& Hendry, 1990; Frydenberg, 1997); y hace referencia a un periodo de cambio, crecimiento y desequilibrio, que permite la transición de la inmadurez física, psicológica, social y sexual de la infancia, a la madurez de la vida adulta futura (Vargas, 2002). El inicio de relaciones íntimas y románticas durante este período coincide con el desarrollo de la identidad y la independencia de vínculos con las figuras parentales, hechos que originan presiones sociales fuertes y provocan la revisión de los patrones existentes en las interacciones sociales (Casullo, 2004). De igual manera, decrece el tiempo que se dedica a las relaciones con padres, amigos y hermanos; aumentando así el que se destina a la pareja de ese momento (Clark, Lempers, Ho, 1990). Estas experiencias de autonomía y vinculación, tanto en contexto familiar como ajeno al hogar, tienen como fin el 
establecimiento del sentido de identidad. En otras palabras, durante la adolescencia, además de aprender a establecer nuevos vínculos de amistad y de romance, el adolescente se reconoce como una persona única y diferentes de los demás, integrando así el concepto que tienen de sí mismos y fortaleciendo su autoestima (Vargas, 2002). En ese sentido, el desarrollo de las relaciones románticas es generalmente un proceso gradual de experimentación, que inicia con una secuencia de relaciones casuales y termina en relaciones mucho más estables y duraderas en la vida adulta (Miller y Benson, 1999).

\subsection{Visión psicodinámica de la elección de pareja}

En esta investigación, se utilizará la teorización de la elección de objeto para poder explicar la elección de pareja futura. Asimismo, utilizaremos el concepto psicoterapéutico insight para poder entender la manera en como cada uno de los sujetos de estudio entienden su propia historia. No obstante, con la finalidad de poder entender ambos conceptos, es importante revisar el término inconsciente. Freud (1912) postuló una primera tópica de la mente en base a 3 conceptos: El consciente, como aquella representación que está presente en nuestra conciencia, de la cual nos percatamos y tenemos acceso de manera constante. El segundo concepto, preconsciente, como aquellos pensamientos o recuerdos latentes, que si bien no son pensados pueden devenir de manera accesible a la consciencia para pasar a un estado consciente. Finalmente, el inconsciente, en donde divagan aquellas representaciones de las cuales el ser humano no se percata, pues debido a su intensidad y movilización, se mantienen alejadas de la conciencia (Freud, 1912). En ese sentido, en el inconsciente el sujeto se topa con aquello desagradable, lo que no quiere hablar o evita recordar, debido a mecanismos de defensa como la represión, así como de evitación de contenidos, los cuales buscan penetrar en la consciencia.

Por consiguiente, para explorar el inconsciente es importante tener cierta capacidad de insight. Esta se entiende como aquella capacidad para pensar las propias motivaciones, así como el autoconocimiento de la significancia inconsciente de actos, sueños, palabras y fantasías, dándole un sentido propio y otorgándole una representación al comportamiento de manera simbólica (Rycroft, 1972). Autores más recientes como Galimberti, la definen como "la nueva comprensión de relaciones que se dan de manera inmediata e imprevista" (Galimberti, 2006, p. 615). No obstante, el 
psicoanálisis la dividió en dos categorías: El insight intelectual que es la capacidad de entender racionalmente las propias actitudes psíquicas, y un insight emocional, que implica una participación afectiva y terapéutica de la misma (Galimberti, 2002, p. 615). Dado ello, para motivos de esta investigación, nos centraremos en el insight emocional, ya que funciona como parte de un descubrimiento propio, en donde se hace conciencia de los conflictos inconscientes, logrando una adecuada y profunda comprensión de nuestra historia (Valdivieso, 2002).

Por otro lado, los estudios psicoanalíticos orientados al amor y la pareja han sido muy pocos a lo largo de los años. Sin embargo, los procesos inconscientes en la estructuración de la pareja han promovido una reflexión - casi siempre - psicoanalítica (Lemaire, 2013). A partir de ello, la teoría que mejor explica este proceso ha sido el de las relaciones objetales. Esta teoría representa el inicio de la naturaleza y origen de las relaciones interpersonales de cada sujeto, Kristeva (2000) menciona que "las relaciones objetales están en el centro de la vida emocional", y por ende son determinantes para las elecciones futuras. Mientras tanto, Coderch (2011) propuso que la vida psíquica de todo sujeto estará determinada por todo lo construido a partir de las relaciones objetales; es decir, desde el primer contacto con la madre al nacer, hasta el contacto continuo con las personas que ha tenido el sujeto a lo largo de su historia.

Laplanche (1996) describe este concepto como el modo de relación del sujeto con su mundo, relación que es el resultado complejo y total de una determinada organización de la personalidad, de una comprensión más o menos fantaseada de los objetos, y de unos tipos de defensa predominantes.

Por otro lado, Fedida (1979), la entiende como una noción integrada a la teoría de la sexualidad, que se refiere a la naturaleza de un lazo fijado a partir de la elección que el sujeto hace de su objeto de amor. En este caso, la noción de elección participa estrechamente de la historia personal (anaclítico, idealización, objeto). Con ello, entendemos la importancia de la relación de objeto primario - entiéndase a la madre como un determinante, en cierta medida, para las futuras elecciones. De esta manera, esta teoría plantea que existe una necesidad primaria de objetos, la cual está ligada a una exploración constante del placer, en donde el yo se encuentra envuelto para dar respuesta a su propia necesidad de relación futura (Ramírez, 2010). En ese sentido, la disposición para enamorarse y formar una pareja supone la capacidad para vincular la idealización de otro y el potencial para establecer una relación objetal profunda (Kernberg, 1997). 
Por ello, el encontrar el objeto de amor futuro es, en cierto modo, reencontrarse con el, pues lo que planteamos respecto a la elección de pareja es que se estaría buscando, o en todo caso, restituyendo el objeto perdido; es decir, un objeto previo. De esta manera, las relaciones objétales sentarían las bases para nuestras futuras relaciones con los otros, y también para la relación consigo mismo; además, influirán también en la salud mental y calidad del mundo interno de cada persona.

Por otro lado, y en cuanto a la elección de objeto homosexual, Coderch (1982) postulaba que ciertos mecanismos conducen a la homosexualidad masculina, los cuales los nominó como "fallas o carencias" de las funciones tempranas del objeto masculino. Estas pueden desarrollarse porque el sujeto evidencia tener una identificación positiva con la imagen femenina, o por el contrario con la identificación masculina.

Finalmente, es importante indicar que, en cuanto a elección de pareja, esta no siempre posibilita la satisfacción, si no que en algunos casos predomina la organización defensiva. Esto dependerá de la historia de vida del sujeto y en conjunto de los involucrados en la relación a sus objetos de amor previos. Dado ello, Freud (1905) postulaba que la elección de objeto se podía dividir en categorías: elección de objeto anaclítica (en donde la elección se da en función a las figuras parentales), y la elección de objeto narcisista (en donde se da una elección en función a lo que uno es, lo que uno fue, lo que uno quiera ser y a la persona que fue una parte de uno mismo). Para motivos de esta investigación utilizaremos lo propuesto por los diferentes autores mencionados para diseñar modelos de elecciones según la historia personal de cada sujeto de estudio.

\subsection{Relación de Amor}

Cuando escuchamos o hablamos de amor, pensamos, casi siempre, en una pareja y en el amor romántico. No obstante, innumerables autores han tratado de conceptualizar el amor y darle un significado de acuerdo a la cultura y la dinámica que configura el momento de sentir, o creer sentir, amor. En la actualidad, este concepto ha dejado de ser estudiado debido a su complejidad y múltiples definiciones (Libia, 2008).

El amor es una de las mayores incógnitas de nuestra sociedad, principalmente por su difícil comprensión. Por lo general desde temprana edad, las familias orientan a sus hijos a buscar un "amor ideal o romántico", el cual llene sus necesidades y expectativas por completo, siendo este un concepto de amor perfecto e idealizado (Barrios \& Pinto, 2008). Sin embargo, no es hasta la adultez temprana donde cobra 
verdadera importancia. Fromm (Citado en, Villanueva 1985), desde su perspectiva, indicaba que elegir pareja se da de manera significativa en esta etapa debido a que el sujeto tiene mayor conciencia sobre su vida y busca saciar sus necesidades afectivas y de relación, las cuales por lo general, se satisfacen en la relación al amor. De esta manera, la conceptualización de amor tiene mucho que ver con las necesidades de intimidad y con los déficit que podríamos tener (Duran, 2014). Por consiguiente, el amor quizás implica un vínculo en el cual uno ha de cubrir todas las fantasías inconscientes del otro, y en donde se busca aquello que no se tiene.

Como sabemos, la pareja es uno más de los tantos vínculos que alguien puede entablar con otra persona, y como una relación familiar, laboral o amical, tiene ciertos modos de funcionamiento que lo caracterizan. Sin embargo, lo que no puede discutirse es que este vínculo en particular se construye sobre la base del amor (Rolón, 2012). Iturralde de Ardavín (1994) define al amor como algo limpio, sincero, inteligente y que busca siempre el bien de la persona que se ama. Sin embargo, con respecto al constructo, Alberoni (2008), concibe en el ser humano dos tendencias innatas: el sexo, que lleva a la exploración y búsqueda de experiencias sexuales; y el enamoramiento, que conduce a buscar una relación profunda, duradera y exclusiva con una sola persona. Yela - García (2001), considera cierto conjunto de pensamientos, sentimientos, motivaciones, reacciones fisiológicas y declaraciones que ocurren en las relaciones interpersonales. La definición del amor variará en función del estado de la relación.

Por otro lado, y desde otras perspectivas, existen distintas teorías que hablan sobre el amor. Una de ellas es la teoría del refuerzo de Albert y Bernice Lott (1961, como se citó en Sternberg, 1989), en la que el ser amado funciona como reforzador de la conducta amorosa, provocando en el individuo relajación y disminución de ansiedad facilitando el enamoramiento. Otra teoría es la teoría del intercambio social de Homans (1974, en Sternberg, 1989), en la que se maximizan las compensaciones y minimizan los desagrados de la pareja. No obstante, Sternberg (1989), entiende el amor como un triángulo en el que cada vértice representa: intimidad (sentimiento de acercamiento), pasión (expresión de deseo y necesidad de autoestima) y compromiso (decisión de mantener el amor). Esta triangulación coincide en lo que muchas personas describen como componentes básicos para su elección de pareja.

Por otro lado, desde una mirada más psicoanalítica, Otto Kernberg (1997), establece el concepto de "amor sexual maduro", el cual supone una disposición emocional que integra los siguientes componentes: 1) la excitación sexual transformada 
en deseo erótico de o por otra persona; 2) la ternura que deriva de la integración de las relaciones de objeto primarias; 3) una identificación empática y genital con el otro; 4) una idealización madura, junto con un compromiso con el otro y la relación, y 5) el carácter apasionado de la relación amorosa tanto en la relación sexual como en la objetal. Además, la elección madura de una persona a este objeto de amor involucra ideales maduros, juicios de valor y metas que satisfagan la necesidades de amor e intimidad, De esta manera, una relación amorosa incluye idealización, ternura, y una forma de identificación con el otro; en donde los intereses, deseos, sentimientos y las carencias del otro llegan a tener - o así se cree - la misma importancia que los propios (Balint, 1948).

\subsection{Elección de Pareja}

Buss (1994, como se citó en Mate \& Acarín, 2011), define la elección de pareja como una estrategia sexual que se ajusta a un problema adaptativo específico, cómo el identificar a la pareja deseable, o superar a los competidores a la hora de atraerla. Además, menciona que por debajo de la estrategia sexual hay ciertos mecanismos psicológicos, como ciertas preferencias específicas de cada género, y en donde los hombres buscan a alguien por su atractivo físico, salud, y capacidad de reproducción, en contraste a las mujeres que buscan que tengan interés en invertir sus recursos en ella y en los hijos que podrían tener (Buss, 1994). También menciona que dentro de esta elección se encuentran eventualmente los rasgos físicos, signos de interés sexual, o que tan proclive a ser infiel se es.

Desde una perspectiva más amplia y social, en un estudio respecto a las estrategias biológicas y psicosocioculturales que intervienen en la elección de la pareja (Valdez, González-Arratia, Torres \& Rocha, 2011), se encontró que frente a la interrogante: ¿Para qué se casó con su pareja?, los hombres mencionan que se casaron para encontrar afecto, afiliación o pertenencia a un grupo, o a alguien que les ayude a cubrir sus necesidades, para así lograr consolidar un compromiso. Frente a esta interrogante, las mujeres respondieron que eligieron a su pareja para tener con quien realizar un trabajo en conjunto, para tener apoyo y para encontrar protección, seguridad y estabilidad (Valdez, González-Arratia, Torres \& Rocha, 2011).

Por otro lado, Álvarez-Gayou (1996), Sternberg (2000) y Martínez (2004), mencionan que dicha elección no solo surge de la atracción física por otra persona, sino 
también la parte intelectual y afectiva, entre otros aspectos, encontrándose que los hombres toman también en cuenta la "forma de ser" de su pareja, la intimidad que puedan establecer con ellas y la comprensión. En tal sentido, tanto hombres como mujeres, desean cubrir sus necesidades de afiliación y tener una relación emocionalmente cercana, ya que para todos los seres humanos las relaciones afectivas son especialmente importantes (Díaz-Loving y Sánchez, 2002).

De esta manera, la elección de pareja no es única y exclusivamente instintiva (Díaz Loving \& Sánchez Aragón, 2004), ya que, a pesar de ser absolutamente natural, han ido entrando en juego los procesos psicológicos y socioculturales que implican la elección de este otro (Valdez, Gonzales \& Lopez, 2007). Asimismo, es importante mencionar que en la elección de pareja no sólo intervienen aspectos biológicos mencionados anteriormente, sino que es muy importante detectar el parecido u opuesto que tiene la persona elegida con el progenitor del mismo sexo (Freud, 1914), el género, sea la parte femenina o masculina que se haya perdido (Fromm, 2000), el contacto con el otro (Álvarez-Gayou, 1996) o bien, las semejanzas (Cerda, García, Galeana, Hernández, Limón, Reséndiz, Ruiz, \& Valenzuela, 2004) y/o la complementariedad (Winch, 1958), que pueden llegar a tener las partes que deciden involucrarse.

Centers (1975), propone que el individuo se siente atraído hacia personas con necesidades complementarias o semejantes a las nuestras. Por otro lado, en un estudio realizado por Adams (1979), durante seis meses con parejas adultas estables, se evidencio que la atracción inicial se basa en cualidades superficiales tales como el atractivo físico, porte, carácter e intereses comunes. La relación se fortalece con las reacciones del entorno, quienes los consideran como pareja, y el sentirse cómodos cuando interactúan juntos. Entonces, la pareja inicia una etapa de compromiso e intimidad, que genera una consolidación del vínculo. Del mismo modo, es importante mencionar que antes de pasar a la etapa del compromiso, se ponen en juego la manera de pensar del otro, costumbres y valores.

Desde una perspectiva psicodinámica, M. Péndola y A. Péndola (2014), mencionan que en la elección de pareja se busca inconscientemente aspectos en relación a la historia de uno; es decir, padres-hermanos-hijos, según haya sido la relación con ellos. Entendemos ello como la búsqueda continua de repetir aspectos infantiles en un principio deseado, tal como lo mencionaron estos autores. De esta manera, se podría decir que la elección de pareja no es casual, debido a que de modo inconsciente se busca que este otro encaje con las necesidades de uno y viceversa. Así pues, se establece un 
vínculo afectivo aceptado - y complementario - de ambas partes conformándose así, una entidad de pareja (Péndola \& Péndola, 2014).

En las relaciones amorosas se desea recrear el contacto con el primer objeto de amor, con las fantasías que suscitó. Estas experiencias que se reprimieron influyen en la atracción sexual, afectiva y de otros aspectos de la persona escogida como pareja. (Willi, 1993 como se citó en Péndola \& Péndola, 2014 p. 21)

De esta manera, los impulsos inconscientes - tanto de uno como del otro convergen para crear "un inconsciente común" que puede desatar una relación de amor saludable o - por defecto - una relación de amor patológica. En ese sentido, García, Garrido y Rodríguez (1993) consideran que la elección que se da entre dos personas no es sino la recreación de emociones sentidas sobre todo en la infancia. En otras palabras, se busca elegir de forma inconsciente los afectos y las vivencias interpersonales que marcaron dicha etapa.

En la misma línea, Montoya (2000) menciona que la elección de pareja no es un hecho circunstancial sino más bien una decisión inconsciente pero sutilmente elaborada. Esto alude a que esta decisión no está solo promovida por los elementos del estímulo físico, sino por las expectativas idealizadas de bienestar y placer básicamente determinadas porque el otro tiene algo nuevo que ofrecer. Esto quiere decir que, a través de mecanismos conscientes y sobretodo, inconscientes, se espera que la persona llene las carencias y resuelva ciertas dificultades que la aquejan, o también el deseo de re editar las experiencias placenteras pasadas. En ese sentido, la experiencia clínica psicoanalítica pone en evidencia que en el inconsciente el pasado se hace presente y que el ser humano se va a vincular con los otros según la relación de apego que haya podido tener en su infancia (Auxi, 2005). Entonces, se entiende que una crianza defectuosa dejaría un vacío emocional que tiene la necesidad de ser llenado por otra persona (Rolón, 2012). Para Freud (1914), la posible elección está predeterminada aludiendo a que el encuentro con el otro es siempre un reencuentro, y por ende, toda elección es sustituida hacia algún objeto previo. Así pues, la atracción amorosa que el niño sintió en su infancia por el progenitor del sexo opuesto se transferirá más tarde a un objeto exogámico socialmente aceptado, que en el mayor de los casos es la pareja (Craig, 1997). Dicho de otra manera, el sujeto busca encontrar aquello que ha perdido a fin de unirse nuevamente con él (Fromm, 1959).

Además, es importante mencionar que Núñez (2008), en su libro "Higiene mental de la familia", explica que los vínculos que se generen en la temprana edad entre 
padre-cuidadores e hijos, determinarán la forma de elección de la pareja en la vida adulta. Es en el grupo familiar de la niñez, en donde se organiza, desarrolla y estructura la vida instintiva y emocional adulta. Si esta etapa es vivida por el niño con mucha angustia, esta perdurará como fijaciones en la adultez, e impedirá que la persona tenga una vida de pareja saludable.

A partir de todo lo expuesto y la recopilación de diferentes artículos que hablan sobre la elección de pareja, el objetivo de esta investigación es comprender el proceso de elección de pareja en participantes que hayan sido parte de un proceso terapéutico de orientación psicodinámica, debido a que esta rama de la psicología permite al sujeto revivir aspectos de su infancia con el fin de resignificarlos en terapia y darle un sentido a su vida actual. Así también, identificar la construcción personal que cada sujeto tiene en función a su experiencia(s) de pareja e historia de vida. En ese sentido, la presente investigación permite entender la elección de pareja de una manera más profunda, dado que los sujetos de estudio han podido reflexionar y profundizar etapas de su vida personal dentro de sus espacios terapéuticos, la aproximación de una realidad social más exacta, en donde las elecciones de pareja empiezan a ser más libres; y romper los esquemas y creencias sociales impuestos con respecto a la elección de pareja. 


\section{Capítulo 3. METODOLOGIA}

La investigación cualitativa descubre las cualidades de un fenómeno (Gonzales Rey, 2006). De esta manera, los investigadores que se apoyan en este tipo de metodología hacen registros narrativos de los fenómenos que son estudiados mediante técnicas como la observación participante y las entrevistas no estructuradas para lograr ver los acontecimientos, acciones y normas. Asimismo, se trata de identificar la naturaleza profunda de las realidades, su sistema de relaciones, su estructura dinámica, con el claro propósito de proveer descripciones detalladas de los contextos estudiados (Martínez, 2007).

Desde un punto de vista epistemológico, la investigación cualitativa mantiene un carácter hermenéutico constructivo-interpretativo del conocimiento (González Rey, 2007). Esto implica reconocer a dicha teoría como una producción que se va desarrollando y construyendo a lo largo de la investigación a través de "zonas de sentido", las cuales permiten crear nuevas construcciones que aportan al modelo teórico propuesto. De esta manera, se logra profundizar en el relato de cada sujeto para lograr comprender su singularidad.

Es por ello, que el presente trabajo de investigación pretende utilizar una metodología cualitativa utilizando los sistemas conversacionales propuestos por González Rey (2007), que permiten al investigador entrar en una dinámica de conversación, la cual va tomando diversas formas y generando trechos de información. No obstante, en este proceso dinámico y vivo de las conversaciones se van elaborando "puentes" relacionados a la historia de vida de la persona, en base a sus propios procesos, conocimientos, generando así una producción humana, en donde el rol del investigador es de alguien que piensa, expone y confronta sus ideas, generando así un diálogo fluido y de expresión libre (González Rey, 2007). De esta manera, es importante identificar aquellos puentes que se enlazan con aspectos de la infancia en función a la creación de los distintos trechos de información (González Rey, 2007). Estos son el resultado de una reflexión realizada durante la conversación, descrita en un discurso que puede ser entendido. Los trechos de información, según Gonzales Rey, son "una expresión viva de la persona que habla, la cual no reconoce limites formales externos a 
la propia necesidad de expresión que se produce dentro del espacio conversacional." (González Rey, 2007, pág. 34)

\subsection{Participantes}

Para la presente investigación se trabajó con 8 informantes, tanto hombres y mujeres entre 24 y 27 años de edad, los cuales asistían o asisten a terapia de orientación psicoanalítica, por lo menos durante 12 meses de continuidad y de formación o profesión en la carrera profesional de Psicología. Es necesario mencionar que todos los participantes son solteros, sin hijos y actualmente se encuentran trabajando en el rubro clínico de la psicología. Adicional a ello, como característica en común se enfatiza en que los informantes identifiquen parejas significativas las cuales consideren importantes a lo largo de su vida; y que les permita poder recordar el proceso de elección de las mismas. No se precisa tiempo de duración o convivencia para dicha inclusión.

Asimismo, se enfatiza en que los informantes estén dentro una etapa de adultez temprana, debido a que en esta se busca la consolidación, la formación y el desarrollo de la pareja, pues forman parte de la identidad personal que se adquiere por ser miembro de una relación estable.

Por otro lado, el criterio de asistir a terapia responde a que ello favorece a la capacidad de insight, como un concepto organizador que otorga una referencia condensada de aquello que se busca y sucede en el vínculo terapéutico (Serrano de Dreifuss, 2012). Asimismo, es importante mencionar que dichas reflexiones no deben llevar a certezas, sino que deben ser entendidas en base a un grupo de personas que están en un proceso de introspección, la cual los lleva a mirarse de manera constante y profunda en terapia, ya que los saberes del inconsciente nunca son resueltos, y parte del proceso de una terapia de orientación psicoanalítica es de identificarlos y hacerlos consciente.

Para contactar a cada participante se empleó la técnica del muestreo en cadena, también conocido como bola de nieve, la cual utiliza a los entrevistados como recurso, al encontrar un caso perteneciente al grupo de objeto de investigación, en donde el informante llevará al siguiente, de manera progresiva, hasta alcanzar la información pertinente para dar por terminada la investigación (Quintana y Montgomery, 2006). Al ser consultados sobre su participación decidieron colaborar y ser parte de la 
investigación de manera voluntaria, lo que genera un desarrollo óptimo del mismo, asegurando la credibilidad y calidad de la misma (Rodríguez, Gil y García, 1996).

No obstante, el cuidado de la información que los informantes del estudio brindaron se manejó estrictamente de manera confidencial, ya que los sujetos solo fueron entrevistados después de haber sido informados de la metodología y de haber firmado un consentimiento informado. En este, accedieron de manera voluntaria a tener una conversación grabada en una sesión, en donde se utilizarían los resultados arrojados para el desarrollo de una tesis. No obstante, y debido a que los contenidos que se trataron son muy íntimos, se mantuvo el anonimato de cada uno de los participantes reemplazando sus nombres por seudónimos.

Tabla 1: Ficha Sociodemográfica

\begin{tabular}{|c|c|c|c|c|c|c|c|}
\hline $\begin{array}{l}\text { Nombre } \\
\text { (supuesto) }\end{array}$ & Sexo & Edad & Estudios & $\begin{array}{c}\text { Estado } \\
\text { Civil }\end{array}$ & Hijos & $\begin{array}{l}\text { Pareja } \\
\text { Actual }\end{array}$ & $\begin{array}{c}\text { Tiempo en } \\
\text { terapia }\end{array}$ \\
\hline Daniel & $\mathrm{H}$ & 24 & $\begin{array}{l}\text { Bachiller en } \\
\text { Psicología }\end{array}$ & Soltero & No & No & 3 años \\
\hline Lucia & $\mathrm{M}$ & 25 & $\begin{array}{l}\text { Bachiller en } \\
\text { Psicología }\end{array}$ & Soltero & No & $\mathrm{Si}$ & 8 años \\
\hline Oscar & $\mathrm{H}$ & 25 & $\begin{array}{l}\text { Bachiller en } \\
\text { Psicología }\end{array}$ & Soltero & No & $\mathrm{Si}$ & $\begin{array}{c}2 \text { años } 10 \\
\text { meses }\end{array}$ \\
\hline Adrián & $\mathrm{H}$ & 27 & $\begin{array}{c}\text { Licenciado } \\
\text { en } \\
\text { Psicología }\end{array}$ & Soltero & No & $\mathrm{Si}$ & $\begin{array}{l}\text { Más de } 10 \\
\text { años }\end{array}$ \\
\hline Sofía & $\mathrm{M}$ & 24 & $\begin{array}{c}\text { Licenciado } \\
\text { en } \\
\text { Psicología }\end{array}$ & Soltero & No & $\mathrm{Si}$ & 5 años \\
\hline Rodrigo & $\mathrm{H}$ & 25 & $\begin{array}{l}\text { Licenciado } \\
\text { en } \\
\text { Psicología }\end{array}$ & Soltero & No & No & 3 años \\
\hline Federico & $\mathrm{H}$ & 24 & $\begin{array}{c}\text { Licenciado } \\
\text { en } \\
\text { Psicología }\end{array}$ & Soltero & No & $\mathrm{Si}$ & 5 años \\
\hline Alexandra & $\mathrm{M}$ & 25 & $\begin{array}{l}\text { Bachiller en } \\
\text { Psicología }\end{array}$ & Soltero & No & $\mathrm{Si}$ & $\begin{array}{c}4 \text { años } 11 \\
\text { meses }\end{array}$ \\
\hline
\end{tabular}

Fuente: Elaboración propia

\subsection{Técnica de Recolección de Información}

La dinámica conversacional (Gonzales Rey, 2006) es un proceso que tiene como objetivo conducir al informante a campos significativos de su experiencia personal. De esta manera, va expresando de forma natural sus conflictos, emociones y reflexiones 
que a su vez van generando otras emociones para así propiciar una dinámica de conversación adecuada, la cual permite a los mismos implicarse en el diálogo conversacional. Asimismo, el investigador tomó el rol de facilitador generando y empleando indicadores, que permitieron darle continuidad a la dinámica conversacional y profundizar de acuerdo al objetivo de investigación (Martínez, 2006). En este sentido, se utilizó una guía semiestructurada para orientar la dinámica conversacional hacia el objetivo de la misma, de modo que se generó una responsabilidad compartida, tanto para el entrevistador, quien va elaborando en base a suposiciones y contrastando información, como del participante, quien va generando un pensamiento reflexivo (Gonzáles Rey, 2006).

Se realizó una entrevista con cada informante que tuvo una duración de 45-70 minutos, en un espacio cerrado y propicio, que facilitó el diálogo, así como la expresión libre del mismo. Dado que el encuentro y el diálogo se dan con sujetos que han sido parte de un proceso de psicoterapia, la capacidad de insight de los participantes facilitó el llegar al análisis pertinente como parte de un proceso de introspección.

De esta manera, se inició la conversación con una pregunta abierta: Cuéntame sobre tu infancia, en donde se buscó conectar al participante con eventos y vínculos significativos de su historia, para luego indagar aspectos ligados a su propia experiencia en base a su proceso de elección de pareja. Finalmente, se concluyó la entrevista con una pregunta clave de cierre: ¿Qué es elección de pareja para ti?, la cual es producto de la reflexión que suscita la entrevista, y el comprender la construcción personal del sujeto a modo de conclusión.

Se realizaron dos pilotos de investigación con ayuda de tres expertos, los cuales permitieron evaluar los instrumentos construidos, para su posterior corrección con la finalidad de afinar los mismos para el recojo de la información, refinar los contenidos y focalizar los procedimientos a seguir en favor al objetivo de la investigación.

\subsection{Procedimiento}

Para motivos de la investigación, como se mencionó anteriormente, se utilizó la técnica del muestreo en cadena, la cual permitió, de forma voluntaria, obtener los informantes necesarios para esta investigación. El primer contacto con los informantes se realizó de manera directa vía telefónica, en donde el investigador procedió a presentarse y explicar en qué consistía la investigación, incluyendo aspectos éticos de 
anonimato y confidencialidad; y en donde al aceptar su participación debería firmar un consentimiento, el cual indicaba su participación de forma voluntaria, y que sería grabada en audio para uso exclusivo de esta (adjunto en el apéndice). Al finalizar cada encuentro, el investigador solicitó al informante la posibilidad de referirle el contacto de sujetos con las características en común explicadas anteriormente.

Se realizó un encuentro por informante, en donde se tuvo como objetivo que estos accedieran a niveles de comprensión de sí mismos, que les permitió entender, reflexionar y focalizar el proceso de su elección de pareja a partir de su historia. Finalmente, se realizó un análisis a profundidad de cada caso, para luego integrar los resultados, los que se discutieron a partir de las investigaciones y/o literatura utilizada (Martínez, 2006).

\subsection{Criterios de Calidad}

Por otro lado, dentro de los procedimientos de calidad, se recurre a diversos criterios y rigor metodológicos que adecuan el diseño de la investigación, la estrategia metodológica, el análisis de la información y la presentación de los resultados aplicados en la investigación cualitativa con el objetivo de asegurar la credibilidad, integridad y autenticidad de los resultados (Cornejo y Salas, 2011). Es por ello que se emplearon cuatro criterios básicos tales como adecuación epistemológica, relevancia, validez y reflexividad (Calderón, 2002).

En cuanto a la adecuación epistemológica, busca reflejar distintos niveles respecto del enfoque cualitativo utilizado en la investigación: definición de la pregunta del estudio, coherencia y modo en el cual se desarrolla la misma, concordancia con las teorías expuestas a lo largo de esta, así como el encuadre planificado previo al estudio.

De ese modo, el enfoque cualitativo de estudio de casos propuesto por Gonzáles Rey (2006) permite un análisis extenso del proceso de la dinámica conversacional, pues incita al investigador a describir, profundizar y analizar la información recopilada, así como el entendimiento de constructos expuestos en base a las teorías revisadas, que surgen para organizar y analizar la experiencia de investigación con la teoría.

Por otro lado, el criterio de relevancia plantea la justificación y alcances del trabajo de investigación, pues es el aporte de conocimiento del fenómeno de estudio, el cual lleva al investigador a un mayor conocimiento de este a partir de los participantes. Por ello, se pensó relevante utilizar una población de psicólogos clínicos en terapia 
psicoanalítica, pues facilita la capacidad de mirarse a sí mismo, asociar aspectos de su historia de vida con aspectos actuales y generar hipótesis que favorecen a la investigación. Es por ello que es importante mencionar el criterio de relevancia, pues representa en cierto modo la importancia de los aspectos descubiertos, así como de la creación de estos mismos, generada por los sujetos de estudio, como de los investigadores en conjunto (Calderón, 2002). El criterio de validez, hace referencia a preservar la adhesión cualitativa del fenómeno estudiado, en base a los instrumentos utilizados, como el análisis de las dinámicas conversacionales a profundidad, el desarrollo, descripción y análisis de lo recogido y contrastado con la teoría psicoanalítica. Por último, el criterio de reflexividad respecto del investigador en base al rol que ejerce como tal, y de la influencia que puede generar sobre los sujetos de investigación, debido a que los métodos que el investigador emplea son expresiones de contextos sociales, académicas, las cuales permiten el desarrollo activo, y que dan cuenta de un proceso de construcción del conocimiento constante (Calderón, 2002). En este criterio, el investigador es consciente de la influencia de su formación, planteamientos y perspectiva en base al abordaje de la investigación, la cual sirve de herramienta en la participación de las dinámicas conversacionales, en donde surgen las asociaciones que permiten emerger las zonas de sentido como parte de la participación subjetiva del investigador (Gonzáles Rey, 2006).

\subsection{Análisis de la Información}

Interpretar la información constituye uno de los momentos claves de la investigación en cuestión e implica un proceso reflexivo a través de la revisión de la información recopilada, con el propósito de descubrir el significado de cada evento o situación desde el punto de vista de los participantes (Martínez, 2006). Para la investigación en cuestión se utilizó el modelo como producción teórica (Gonzales Rey, 2007), en donde la construcción teórica que se va suscitando a lo largo de la dinámica conversacional se contrastan a partir de la reflexión del investigador con los modelos y teorías planteadas en el marco de la investigación estudiada. Dado ello, se analizó a profundidad las posibles carencias, en partes conscientes e inconscientes, que han predominado a lo largo de los años en los participantes; identificando la singularidad de cada sujeto en función a su elección de pareja y repercusiones, así como patrones continuos en la elección identificados por el informante. 
Finalizada la dinámica conversacional con cada informante, se realizó un análisis de datos integrador, para lo cual se plantearon tres ejes principales presentes en la mayoría de casos. Una vez analizados los ejes, se identificaron las categorías que posteriormente dieron los resultados de cada informante. La explicación de cada eje/categoría se procederá a describir en el capítulo de resultados.

Tabla 2: Ejes de sentido

\begin{tabular}{|c|c|c|}
\hline Eje de sentido & Eje de sentido subjetivo & Resultados \\
\hline \multirow[b]{2}{*}{$\begin{array}{l}\text { 1. Aspectos } \\
\text { Conscientes }\end{array}$} & & $\begin{array}{l}\text { Expectativas conscientes en la } \\
\text { elección de pareja en función a } \\
\text { valores. }\end{array}$ \\
\hline & & $\begin{array}{l}\text { Expectativas conscientes en la } \\
\text { elección de pareja en función a su } \\
\text { personalidad }\end{array}$ \\
\hline \multirow{6}{*}{$\begin{array}{l}\text { 2. Aspectos } \\
\text { Inconscientes }\end{array}$} & & 2.1.1 Elección de tipo narcisista \\
\hline & $\begin{array}{l}\text { 2.1 Patrones en la elección de } \\
\text { pareja }\end{array}$ & $\begin{array}{l}\text { 2.1.2 Elección por aceptación } \\
\text { emocional }\end{array}$ \\
\hline & \multirow{4}{*}{$\begin{array}{l}\text { 2.2 Características y/o } \\
\text { cualidades en función a } \\
\text { figuras parentales }\end{array}$} & 2.1.3 Elección Circunstancial \\
\hline & & 2.2.1 Elección anaclítica \\
\hline & & 2.2.2 Elección anaclítica materna \\
\hline & & 2.2.3 Elección anaclítica paterna \\
\hline $\begin{array}{l}\text { 3. Construcción } \\
\text { personal de la } \\
\text { noción en la }\end{array}$ & & 3.1 Elección Voluntaria \\
\hline $\begin{array}{l}\text { Elección de } \\
\text { pareja }\end{array}$ & & 3.2 Elección no Voluntaria \\
\hline
\end{tabular}

Fuente: Elaboración propia 


\section{Capítulo 4. RESULTADOS}

Las dinámicas conversacionales se analizaron a partir de los ejes y categorías presentados anteriormente, en donde se procedió a describir los resultados obtenidos, según las descripciones de los informantes en función a cada proceso individual de elección de pareja de los mismos.

\subsection{Eje 1: Aspectos conscientes}

Comprende las motivaciones conscientes que tiene el informante al momento de elegir una pareja, en base a expectativas de los jóvenes, categorías sociales comunes, afinidad de valores y rasgos compartidos y complementarios de la personalidad. Dentro de este, se obtuvieron dos posibilidades en base a las respuestas de los informantes: La primera posibilidad, evidencia aquellas expectativas conscientes en la elección de pareja, esta está relacionada con las representaciones de pareja que posee el sujeto en base aspectos personales, en cuanto a ideales, valores y expectativas frente a su elección.

En el caso de Sofía, hace alusión a expectativas y valores importantes para ella en cuanto a la persona que busca elegir. Ello está ligado a sus propios ideales de vida, y deben ser complementarios; es decir, que ambos proyectos de vida se entrelacen formando un solo objetivo en común. Por otro lado, en el caso de Federico, se observa una elección en la cual busca que se le integre como pareja tanto en su vida social como familiar. Esto principalmente debido a la orientación sexual del informante, ya que este busca que su relación sea "visible", es decir, que no tengan que ocultarse debido a los prejuicios sociales.

"Me importa mucho la conexión, lo que otros pueden llamar química, el hecho de que me pueda llevar bien con esa persona, que me sienta tranquila y segura siendo yo misma, y que esta persona también se sienta igual conmigo. Me importa mucho que la persona sea una persona que le importe su vida, en el sentido de que le dé un sentido, por lo mismo que yo le doy importancia a la 
mía, que también tenga metas en la vida, y que apunte a ellas". (Entrevista a Sofía, 24 años, Mayo 2016).

"Me gustaba que se lleve bien con mis amigos, con mi mamá, con mi hermana. En cambio con el otro, nadie lo conocía \{primera relación\}, bueno él tampoco se dejaba conocer, mi mejor amiga sólo lo vio dos veces, con eso te digo todo. Que las personas que yo quiero, puedan conocer a mi pareja, porque finalmente es mi pareja, no es mi amigo, no es mi "brother", es mi pareja. Mi chico ideal es como el que tengo ahorita \{pareja actual\}, sabe lo que quiere, chambea, tranquilo, no me oculta, no lo oculto, no tengo ningún problema". (Entrevista a Federico, 24 años, Julio 2016)

El segundo resultado, el cual engloba aquellas expectativas de la elección de pareja en función de su personalidad, se evidencia la elección en base a ciertas características personales y rasgos que este busca como determinantes al momento de su elección.

En el caso de Adrián, informante homosexual, se evidencian atributos de la propia persona, que finalmente podrían ser proyección de sus propios ideales en cuanto a su elección. Por ello, podríamos estar hablando de una elección complementaria de personalidades, en donde ambas partes se complementan en función a distintas características personales. Por otro lado, en el caso de Oscar, refiere de manera concreta aspectos de personalidad que no deben faltar en su pareja, como son la autenticidad. Adicional a ello, Oscar busca que su pareja tenga un grado de autoconocimiento importante y que esté orientada al otro.

"Cuando su personalidad me jala, me mueve, yo siento que hay como algo, porque mi enamorado actual físicamente no es la persona en la que me hubiese fijado desde un principio. Entonces, en la conversación que tuvimos, me gustó. Si bien yo puedo ser muy visual a veces, la personalidad al final es lo que tiene más peso". (Entrevista a Adrián, 27 años, Julio 2016).

"Que sea auténtica, creo que todas las chicas que me han gustado, sobre todo mi enamorada actual, tienen como su propia personalidad, que se conocen así mismas, pero que saben cómo son y les gusta mostrarse como son, y no mostrarse con máscaras o con fachadas, eso siempre me ha jalado. Que sean personas buenas, que siempre vean el lado bueno de las cosas, el querer ayudar. El que tenga una mirada a mejorar las cosas, a la sociedad, no sólo pensar en ti, 
sino en los demás. Que sean mujeres que disfruten de los espacios culturales, también me gusta que sea creativa: abierta a experiencias distintas". (Entrevista a Oscar, 24 años, Julio 2016)

\subsection{Eje 2: Aspectos inconscientes}

Hace referencia a la recreación de los primeros objetos de amor en la actualidad; es decir, con la pareja. En esta elección se busca, de manera inconsciente, aspectos o vínculos que recrean la propia historia del sujeto, hayan sido estas experiencias difíciles o satisfactorias en la infancia. En este, se obtuvieron respuestas que permitieron dividirlas en distintas categorías. La primera categoría, Patrones en la elección de pareja, la cual evidencia aspectos de relación de pareja que se repiten en las distintas elecciones que haya tenido el informarte, buscando explorar si es que existen patrones de nivel emocional que hayan despertado el interés del informante en su elección. Se obtuvo como respuesta tres posibilidades. La primera posibilidad, muestra un modo de 1. Elección de tipo narcisista. Esta elección está basada en la relación que tiene uno consigo mismo; es decir, en esta se busca elegir a alguien que pueda ser aquel ideal a lo que uno es, lo que uno fue, lo que uno quisiera ser, y a la persona que fue una parte de uno mismo (Freud, 1914).

Daniel refiere que su elección va en busca de sentirse él como apoyo dentro de la relación, en donde evidenciaría una fijación en cuanto al aspecto de ayudar frente a un problema que la pareja tenga, y que está ligado al deseo de ser la contención en la relación. Por otro lado, Rodrigo reconoce que hay un patrón de repetición en cuanto a sus tres últimas parejas, ejerciendo así un rol contenedor, en base a las necesidades de estas, en donde ejercería el rol de sostener a la otra persona. En ambos, se puede ver una elección de objeto narcisista, en donde el tipo de elección de objeto se efectúa sobre el modelo de la relación del sujeto con su propia persona, y en la cual el objeto representa a la propia persona en alguno de sus aspectos.

En ese sentido, en ambos casos se puede entender que dicha elección se dio por una necesidad del informante de contener a su pareja, que puede ser entendida como una proyección en la pareja en base a las propias demandas o por una sobrecompensación, entendida como una necesidad de ser uno mismo el sujeto contenido. 
"El tema del que tengan un problema, ayudarlas... Es como si alguien que está contigo se apoya en ti, a pesar de la carga, la locura, o los problemas que van ya con ella, que están dentro de ella, ella sabe que se puede apoyar en ti”. (Entrevista a Daniel, 25 años, Junio 2016)

"Quizás por el lado que mis últimas tres enamoradas siempre en momentos como de tensión o frustración, siempre me he sentido que soy yo el que tiene que contenerlas (...). Casi que por momento he hecho cosas de psicólogo con ellas, yo como contendor de ellas porque lo necesitaban”. (Entrevista a Rodrigo, 25 años, Junio 2016)

Otra posibilidad es la, 2. Búsqueda de aceptación emocional, que tiene que ver con el deseo del informante de encontrar a alguien que lo acepte tal y como es y viceversa, el cual indica la necesidad del informante de ser comprendido y aceptado.

En el caso de Lucía, reconoce que hay una repetición, aspectos en común, en cuanto a su elección en donde busca aceptar y ser aceptada. Esto estaría relacionado en la necesidad del informante de que la valoren y respeten, y de poder ejercer su propia autonomía. Sin embargo, en el caso de Federico, este busca elegir a una persona que le permita ser quien quiere ser, y que lo acepte y contenga según su opción sexual. En ambos casos, se evidencia de manera inconsciente, la contención emocional como un determinante fundamental en su elección.

Por último, la elección de pareja circunstancial, describe una elección "porque sí" en donde se elige a una persona con el objetivo de mantener el vínculo mediante la idealización. Lo que ayuda, de alguna manera, a protegerse, evadir o escapar, del posible dolor que podría significar perder a una pareja producto de una carencia emocional infantil.

"Pienso que la estabilidad... Bueno he tenido dos parejas, y creo que es eso. La calma, la honestidad, el respeto: que me hayan dejado ser quien soy, no querer cambiar nada de tu pareja, eso valoro y me gusta". (Entrevista a Lucia, 25 años, Mayo 2016)

$\{\ldots\}$ Antes no estaba muy seguro, porque mi primera relación fue muy caótica y fue la primera. De hecho fueron 3 años. Lo conocí en una obra, pero él está muy enclosetado, muy muy enclosetado. Y más aún, a mí me decía que no era gay el “brother”. Para él yo sí fui su primer todo, porque según él, él siempre fue heterosexual, pero mentira pes. Él es una persona muy enclosetada, es del 
medio, es famoso, es conocido, y fue muy caótico, nos peleábamos todo el día, nos veíamos y nos peleábamos. Y ahí yo me di cuenta que no quería eso, esconderme. $\{\ldots\}$ Creo que eso es lo que busco ahora, no esconderme. (Entrevista a Federico, 24 años, Julio 2016)

Adrián reconoce que hay un patrón que se repite, pues hace énfasis en que él aceptaba con quien involucrarse, más no estar seguro de ello. En ese sentido, se evidencia una desvalorización narcisista: aceptar - rechazar, pues no hay dos sujetos en relación, sino de uno solo. Adrián estaría fijado en un lugar de quien no obtiene lo que desea, o que este mismo no sería suficiente para otro, debido a la desvalorización narcisista anteriormente mencionada.

"Como yo muchas veces me he sentido incapaz de conseguir algo, muchas veces aceptaba lo que venía. A veces eso me ha fastidiado, porque de todas las personas con las que me he involucrado: ¿Cuántas personas han sido realmente las que me han gustado? Yo aceptaba lo que venía, bueno yo lo permitía". (Entrevista a Adrián, 27 años, Julio 2016)

En cuanto a la segunda categoría, Características y/o cualidades de la pareja en relación a sus figuras parentales, que tiene que ver con los aspectos y/o características de los padres que se repiten en la elección de los informantes, busca comprender si es que dichas características de relación que existió entre el informante y sus padres se repite o no con sus parejas. Se obtuvieron tres tipos de posibilidades. En primer lugar, se identificó solo una respuesta que ponía la identificación con el padre como patrón de elección. Esto podría deberse a, ya sea por un buen vínculo establecido en la infancia o por oposición.

La identificación anaclítica, como resultado de un buen vínculo tanto paterno como materno, lo que impulsa al informante a elegir pareja en función al patrón de pareja que aprendió desde su infancia. Es decir, se busca imitar la relación de amor de los padres.

En este caso tanto Adrián como Lucía, buscan recrear el vínculo parental que se dio en la infancia. Se encontró entonces una elección de objeto anaclítica, enfatizando, en el caso de Adrián, a el vínculo primario paterno. El tipo de elección podría estar marcada debido a que el informante es homosexual, y evidencia un deseo de ser 
aceptado, el cual no obtuvo frente a su padre, y por ello es recreado en la actualidad frente a sus vínculos.

Por otro lado, en el caso de Alexandra, buscaba relacionarse de la misma manera que aprendió a hacerlo en su infancia, en donde menciona que se sentía sola, como consecuencia de una depresión vivenciada por las figuras paternales. Dado ello, buscaba recrear en sus relaciones este aspecto vinculante en donde sus parejas la iban a rechazar, repitiendo así su historia infantil.

"Mi mamá con mi enamorado actual, ambos son personas reservadas, o sea en el sentido de que son personas que no necesariamente se van abrir fácilmente o contarte algo de ellos. Son personas que valoran esa privacidad que tienen. No son los que más hablan, entonces de algún modo fue difícil que se empiecen a contactar. De hecho también en mi familia la mayoría son fotógrafos, mi papá lo era, mi mamá lo es, y creo que ellos se parecen a los psicólogos, son súper observadores, Y tienen encuadres de la vida muy distintos a los de las demás personas, ya que buscan formas de ver la vida súper enriquecedoras. Y Miguel \{pareja actual\} es un creativo, es súper observador, y te saca muchas veces con sus opiniones, puede también ver las cosas desde distintos ángulos, mi mamá y mi papá son así”. (Entrevista a Lucia, 25 años, Mayo 2016)

"Con mi pareja, como te comenté es un poco como una mamá, que le gusta hacerse cargo de todo y de todos. Y mi mamá es un poco así, no por gusto se hizo cargo de mi papá que sufría de alcoholismo, por tantos años, mi mamá estuvo más de 20 años así. Respecto a mi papá, mi pareja también de repente me ha ayudado a sacar ese lado más juguetón que tengo, que antes por ahí lo tenía, pero nunca lo había mostrado, y mi papá es como un niño. Y en el caso de este chico con el que fue mi primera relación sexual y sólo lo vi una vez, de hecho me ha marcado más que otras cosas... a veces lo pienso. Creo que su actitud, súper creído, no sé mi papá también es así. Y físicamente tienen onda, son agraciados los dos. No sé si me impactó tanto él, porque no sentí de él, la aceptación que buscaba tener, y tampoco la he sentido por parte de mi papá. Porque mi papá siempre, volcó muchas de sus propias frustraciones en mí". (Entrevista a Adrían, 27 años, Julio 2016)

"Pero con los que salía al comienzo se mostraban súper interesados y de ahí desaparecían: Creo que todo el inconsciente que me movía a estos hombres que finalmente me iban a rechazar o iban a desaparecer, ese patrón de vínculo no se 
consolidaba, sino que se largaban. Tuve que llegar finalmente al chico que me “cago" en mi cara, para poder salir de eso. Este patrón que posiblemente sea el rechazo, asumo que en mi infancia, niñez, con que mi mama estaba deprimida, ansiosa, y mi papá abocado a ella, probablemente tiene que ver con eso: Como una niña que se siente sola, rechazada, entonces en todo mí proceso es a lo que he llegado a deducir y me suena lógico”. (Entrevista a Alexandra, 25 años, Junio 2016)

Se puede entender la elección de Sofía como una elección de objeto anaclítica, ya que esta tiene que ver con el objeto de amor que se elige sobre el modelo de las figuras parentales, en tanto estas den soporte y contención y se re-construyan aspectos infantiles. En el caso de Sofía, ella elije de manera inconsciente aspectos en su pareja iguales a la de su padre.

"Mi pareja actual es economista como mi padre, también tiene ciertas características que mi pareja actual tiene. Los dos son meticuloso, sensibles, buscan lo mejor para quienes lo rodean". (Entrevista a Sofía, 24 años, Mayo 2016)

No obstante, también se encontraron respuestas que están orientadas a la identificación con el vínculo materno. Estas respuestas sostienen que las experiencias infantiles del informante con la madre han sido los determinantes primarios que se han dado en el momento de elegir pareja.

Como en el caso anterior, la elección de Oscar está orientada al vínculo materno y de protección, por lo que se enmarca dentro de un tipo de elección anaclítica, debido a que se elige según las bases de la de la figura materna.

“Ahora que lo pienso, más con mi mamá... De hecho con mi mamá siempre, frente algún conflicto, tuvimos como una cierta complicidad, medio de protección. Yo la cuidaba un montón a ella, y viceversa, de entendernos hablando, de estar preocupados el uno por el otro. Teníamos un espacio y conversábamos de los hechos, de lo que nos molestaba, era un es espacio seguro, y en cierto modo lo tengo ahora con Pamela \{pareja actual\} y eso es bueno". (Entrevista a Oscar, 25 años, Junio 2016) 
Por otro lado, los resultados orientados a el vínculo primario materno, muestran que los informantes generan insights más profundos con respecto al vínculo que se dio en la diada madre-hijo, lo que busca recrear o no este objeto primario.

De esta manera, en el caso de Alexandra, explica el patrón en la elección de repetir el objeto, tratando de reparar aspectos de su infancia relacionados al vínculo materno. En ese sentido, se podría evidenciar una elección de objeto de amor más infantil, relacionado a una compulsión en la repetición.

"Fácil este patrón inconsciente de que todos los chicos me iban a rechazar, quizás el patrón de vínculo. Me imagino que es algo de mi niñez, fácil algo con mi mamá que estaba en depresión y bueno yo de niña me sentía sola... Rechazada". (Entrevista a Alexandra, 25 años, Julio 2016)

En este caso, Sofía explica la importancia de repetir el objeto de amor elegido en la infancia, que no es otra que la madre. Esta recreación infantil tiene un rol protagónico en el momento de elegir pareja, por lo que consideramos esta elección va en función de una lección de objeto de amor conocido.

"El apego de hecho, me parece bravazo esto de ver como los vínculos primarios, tanto de mi papá y mamá, el holding y la búsqueda confianza y seguridad la puedas encontrar en tu pareja, me parece básico. También que seas capaz de estar tranquilo y feliz, pero también capaz de hacer tu vida tranquilo, la "base segura", saber que si haces tus cosas y te vas cuando regreses él va estar ahí, todo esto porque me considero una persona bastante independiente. Cuando siento personas muy intrusivas me alejo, porque siento que me invaden". (Entrevista a Sofía, 25 años, Mayo 2016)

\subsection{Eje 3: Construcción personal de la noción frente a la elección de pareja}

El cual tiene como objetivo entender las fantasías y expectativas que tiene el informante en base a la experiencia personal que ha tenido al momento de elegir o no pareja. Se obtuvieron dos tipos de respuestas de los informantes: El primer resultado, evidencia una construcción pensada como una elección voluntaria, la cual realiza el informante frente a su elección, en base a su propia experiencia. Dicha elección es planteada como 
un encuentro que se da frente a un otro, en donde uno escoge y elige con quien compartir de manera espontánea.

Tanto en el caso de Daniel, como de Adrián, en base a su propia historia, hechos significativos y experiencia, postulan que la elección de pareja es un hecho consciente, en donde la persona elegiría en base a expectativas, ideales, gustos, en donde uno se vincula en cierto modo por aquellas carencias que se complementan frente a otro.

Respecto del segundo resultado, el cual enfatiza en una elección no voluntaria, en base a su propia experiencia, se describe el proceso de elección como un hecho circunstancial, una suerte de destino, en donde la elección no se elige, pues se construye con el tiempo o en base a los sentimientos se da.

“Uno elige, lo busca, definitivamente es una elección. Hay procesos más cortos, más largos, pero finalmente es una elección. El hecho de que pase es que has hecho una elección, en base a expectativas, a un "checklist", en base a aspiraciones, a ciertos requisitos, o simplemente porque es una persona sexual, pasional, que te atrae de tal modo. Y es natural, lo demás se da". (Entrevista a Daniel, 24 años, Junio 2016).

"Es lo que eliges. Porque yo no en el amor así nomás no creo, simplemente creo que hay enganches, un poco en base a cómo eres tú, cómo ha sido tu experiencia en base a quienes son tus padres. Y tú solamente a veces encuentras un gancho con alguien. Ese gancho vendría a ser el vínculo, en el cual pegas con alguien. Ese gancho, claro a veces es sano y a veces no. Entonces yo creo que es un poco eso, por eso es que uno se enamora, porque encuentra esas cosas. Pienso que es un tema básicamente súper psicológico, y químico”. (Entrevista a Adrián, 27 años, Julio 2016)

En el caso de Lucía, maneja un discurso en base a una elección circunstancial, postulando más a una elección que se da porque sí. Esta elección tiene que ver los aspectos inconscientes de la otra persona. La experiencia que tendrá el sujeto desde su infancia es vital para construcción de este tipo de elección. Adicional a ello, la informante enfatiza en la construcción de la pareja, que no es más que una manera de buscar reconstruir los aspectos inconscientes sanos que aprendió en su niñez. Por otro lado, en el caso de Oscar, este hace referencia a la elección como una mutua elección, que se grafica como una complementariedad de aspectos inconscientes de cada uno que enganchan frente otro. 
Finalmente, en el caso de Federico, menciona en un primer momento que uno no elije, y que básicamente se da "por qué si". Sin embargo, se entiende que en su historia el sí busca ciertos aspectos - de manera inconsciente - que le permitan poder funcionar como pareja, como el ser aceptado, valorado e involucrado. Adicional a ello, hace énfasis en la personalidad, lo cual nos hace pensar que podría haber cierto contenido consciente. No obstante, esta construcción no es más que una representación de toda su historia de vida, que engloba, desde sus sentimientos de soledad hasta el de ser aceptado.

"Yo no sé si hay elección de pareja en verdad. Pero si creo que la vida te pone en el lugar para encontrarte con las personas que debes encontrar: a nivel de pareja y a nivel de amistad. Los vínculos que importan aparecen en la vida de uno. Lo que sí creo que hay es una construcción de pareja, porque uno construye a la pareja cuando uno está ahí metido, en el proceso". (Entrevista a Lucía, 25 años, Mayo 2016)

"Es darte cuenta de lo sientes hacia otra persona, de lo que puede haber frente a esta persona, de lo que sientes y lo quieres, y empujarse a conseguirlo. Es como una mutua elección, en donde nunca se escoge, pero es un proceso en el que te das cuenta que quieres estar con alguien, que hay una persona con la que te sientes distinto que el resto de personas: Intentar que pase”. (Entrevista a Oscar, 25 años, Junio 2016)

"Uno no elige, uno es totalmente diferente al otro. Uno camina donde está la bioferia de barranco y "pum", se enamora ¿me entiendes? No es que elijo, particularmente, no sé si es válido decir eso. Nos gustaría, creo, poder elegir, el hacer un "checklist" de ya, me gusta esto, me gusta lo otro, pero no, no funciona así. Si el día de mañana termino con el chico con el que estoy ahorita, qué me dice si la persona siguiente con la que este sea la más juerguera y economista en un banco, pero lo quiero. Y claro, la personalidad atrae". (Entrevista a Federico, 24 años, Julio 2016). 


\section{Capítulo 5. DISCUSION}

El objetivo del presente trabajo de investigación fue comprender el proceso de elección de pareja en participantes que hayan sido parte de un proceso terapéutico de corte psicodinámico. Así también, identificar la construcción personal de cada sujeto en función a su experiencia de pareja. De acuerdo al Eje 1: Aspectos Conscientes, dentro de los hallazgos más importantes, en función a la experiencia los participantes, la concepción de una elección de pareja estaría ligada a una búsqueda de un otro más sano, en base a características particulares complementarias e ideales de vida a futuro, dejando de lado aspectos físicos que antes se manifestaban en sujetos jóvenes. Ello podría ser consecuencia, de la mirada propia de los participantes, ya que se encuentran en un proceso constante de mirarse y entenderse, en base a su propia historia, lo que podría llevarlos a una elección de pareja más elaborada; es decir, se da una mayor consciencia de lo que se busca y se quiere elegir como pareja. Adicional a ello, el estar en un proceso de continua mirada hacia uno mismo, se ha podido desarrollar una capacidad de introspección importante que favorece la dinámica conversacional. En ese sentido, consideramos que los participantes lograron relacionar experiencias infantiles con estrecha relación a sus elecciones actuales.

De esta manera, en base a los sujetos, material analizado y el objetivo del estudio, se observa una elección de pareja, en donde el otro ya no es tanto un acompañante sexual, sino un complemento, un compañero de vida, dejando de lado la elección en base a aspectos observables. Consideramos que ello se estaría dando por dos principales razones. En primer lugar, debido a que nuestros participantes se encuentran dentro de un espacio terapéutico, permite que la elección de pareja de los mismos, como mencionamos anteriormente, más elaborada. Esto principalmente como consecuencia de que han profundizado distintas etapas de su vida personal en sus propios espacios terapéuticos, lo cual favorece a un mayor conocimiento personal, que a su vez influye en la manera de vincularse o buscar pareja, ya que al haber interiorizado a profundidad su propia historia, tienen en gran medida mayor consciencia de lo que podrían estar buscando. Ello se valida con la investigación de Schedler (2014), en donde menciona que la terapia de orientación psicoanalítica pone un énfasis importante en las relaciones 
y la propia experiencia personal y social del paciente. Por su parte, Sandler (1993) sostiene que el aumento de insight en terapia se da de acuerdo a las intervenciones del analista, generando así una reintegración de la propia historia y creando nuevos aspectos en la reorganización psíquica del sujeto. No obstante, es importante mencionar que el proceso terapéutico permite que los aspectos adaptativos como los no adaptativos de la personalidad, el concepto de uno mismo, las relaciones afectivas, y las complejidades que surgen con frecuencia en la vida de cada uno, interfieran en la capacidad del sujeto para satisfacer sus propias necesidades.

En segundo lugar, las edades y el grado de madurez de los sujetos de estudio podrían ser de gran influencia también. Esto debido a que se encuentran en un período caracterizado por la progresiva autonomía, la madurez psicológica, la productividad y la capacidad de ocuparse de personas dependientes (Uriarte, 2007). Los participantes de esta investigación han sido parte de un proceso terapéutico durante por lo menos 12 meses, así como la formación que han tenido durante 6 años como psicólogos, con lo cual se podría evidenciar un grado de madurez que va forjándose durante el proceso de terapia, y que lleva a una introspección mayor a partir de su historia:

A partir de la historia, también buscamos insights, en el sentido de que el sujeto se aproxime y acceda a niveles de comprensión tolerante de aspectos de sí mismo, básicamente en el sentido de entender qué lo lleva a estar de esta manera con tal queja, síntoma o demanda en este momento de su vida. Igualmente, se busca el insight en términos de recursos - pues toda crisis es también una oportunidad - no solo para que lo entienda el terapeuta si no el paciente mismo. (Serrano de Dreifuss, 2012, p. 42)

En esta misma línea, la formación y el desarrollo de la pareja son fundamentales en esta etapa, pues forman parte de la identidad personal que se adquiere por ser miembro de una relación estable, pues muchas relaciones amorosas se consolidan y buscan contraer matrimonio entrando a la adultez (Craig, 2001).

Por otro lado, debido a que la búsqueda de pareja está orientada a aspectos más personales, tal como lo mencionan Mate y Acarí (2011) en su estudio sobre elección de pareja. Ambos autores encontraron que las mujeres valoran más que los hombres la sinceridad, por tanto los hombres estarían orientados a la búsqueda de una mujer inteligente y en la que puedan confiar. También las mujeres valoran, más que los hombres, la comprensión y la fidelidad. De esta manera, se encuentra que la elección de pareja empieza a orientarse en mayor medida a aspectos personales por encima de lo físico. 
Nuestros resultados se dan de forma contraria a otros estudios, tales como los de Medina, González-Arratia, Valdez, López (2007), en donde se encontró que en la elección de pareja, tanto hombres como mujeres, dieron importancia a aspectos físicos por encima de los emocionales y/o personales. De manera similar, se encontró que otras investigaciones evidenciaron que los hombres están más preocupados por la relación corporal y atracción física en mujeres (Jiménez, 2003; Garduño, 2002), esto se da a diferencia de los resultados obtenidos en esta investigación, pues se muestra una elección en base a valores y aspectos de la personalidad. Precht (2011), postula que en la actualidad, el romanticismo es una demanda presente en distintas situaciones, contextos de la vida, los cuales están envueltos de pasión, entendimiento, emoción, y cuidado, pero también se habla de que estos aspectos estarían ligados a una falta que busca ser completada - en cierta medida - por el otro, y para que ello ocurra ambas personalidades tienen que coincidir. Del mismo modo, Lemaire (1986) postula que mientras más se va formando en el tiempo una pareja, se van evidenciando con mayor intensidad más elementos, de los que anteriormente ya se tenían, que estarían cubriendo aquellas carencias infantiles pendientes, a ello lo conocemos como carencias inconscientes.

En ese sentido, en cuanto al Eje 2: Aspectos Inconscientes, se evidencia que la relación de objeto primario aparece en la mayoría de los informantes como un patrón en su elección de pareja (Klein, 1932). Asimismo, los resultados alcanzados en este eje, se dan principalmente por 4 modalidades: Elección de tipo anaclítica, Elección de tipo narcisista, Elección circunstancial y Elección por aceptación emocional. Para Klein (1932), las relaciones de objeto temprano, centran las bases para nuestras futuras relaciones con los otros, y también para la relación consigo mismo; además, influirán también en la salud mental y calidad del mundo interno de cada persona. Dado ello, consideramos que lo que sucede con nuestros participantes, en su mayoría, es la reelección de un objeto primario previo; es decir, los padres. Como diría Freud (1914), el encuentro con el otro es siempre un reencuentro, $y$, por ende, toda elección es sustituta hacia algún objeto previo. Es por ello de que habla que dichos patrones aprendidos entre madre - hijo, padre - hijo, son los prototipos de encuentros posteriores, recapitulando dichas dinámicas, tensiones y gratificaciones anteriormente vivenciadas. En ese sentido, en esta investigación se encontró como elección predominante la elección anaclítica, la cual tiene como base aquel vínculo consolidado en los primeros años de vida, tanto paterno y/o materno, lo que mueve a la persona a una elección conocida; en 
todo caso, a una reelección. Es por ello, Zeiman y Hazan (1997) sostuvieron que las elecciones de pareja forman parte del desarrollo de los vínculos sanos obtenidos en la infancia. Asimismo, autores postulan que el vínculo de pareja es de suma importancia para el funcionamiento de los sistemas de apego, sexualidad y afiliación (Furman y Wehner, 1997 como se citó en Casullo, 2003). Lo que nos hablaría de que, en gran medida, los sujetos de esta investigación al haber mantenido un vínculo sano con sus figuras parentales, la elección que están realizando estaría orientada a recrear dichos aspectos sanos obtenidos en la infancia.

En base a lo analizado en la elección de tipo narcisista, dos de nuestros participantes mostraron un rol contenedor repetitivo en sus distintas elecciones de pareja, en donde estaría de manera inconsciente una búsqueda de reconocimiento al ejercer dicho rol. En ese sentido, cuando el narcisismo está equilibrado, uno no necesita demostrarlo y recibir tanto el reconocimiento en base a un otro. Es por ello que en gran medida este tipo de elección se vincula a una búsqueda constante de ser mirado y reconocido en base a otro (Moi y Sanz, 2009). De igual manera, esta elección también está sustentada bajo lo que menciona Tordjman (1989), en donde el amante descubre en el amado una gran complementariedad, ella o él es todo lo que hubiera deseado llegar a ser. En él/ella encontramos una parte de nosotros mismos, reprimida o sublimada. Por otro lado, en cuanto a la elección de tipo anaclítica, se valida lo planteado en la teoría con respecto a dicha elección, en donde se toma por objetos sexuales aquellos que están asociados a vivencias de satisfacción previas; es decir, los objetos de amor primarios. Menciona Freud (1914) "las primeras satisfacciones sexuales autoeróticas son vivenciadas a remolque de funciones vitales que sirven para la autoconservación”. Y es por ello que se obtuvieron respuestas en base a esta relación aprendida, haya sido mediante el objeto maternal, paternal, o ambas, mediante la contención, el holding y la comprensión, y que posteriormente buscarán una identificación de estos con sus propias parejas, en base a un modelo de autoconservación anteriormente aprendido y conocido en la infancia.

En cuanto al eje 3: Construcción personal de la noción en la Elección de pareja de cada participante, se encontró 2 posturas diferentes. Algunos participantes refieren que la elección de pareja es voluntaria, en contraste a otros que afirman que es no voluntaria; es decir, no eligen a su pareja si no que se da de una manera circunstancial. De acuerdo con Péndola y Péndola (2014), 
La elección de pareja no es casual, debido a que de modo inconsciente se busca que este otro encaje con las necesidades de uno y viceversa. Así pues, se establece un vínculo afectivo aceptado y complementario de ambas partes conformándose así, una entidad de pareja.

Esto nos permite entender que de alguna manera los participantes eligen a su pareja debido a carencias infantiles no resueltas y que se pretenden saciar en la pareja. Winch (1972) explica que la elección de pareja se articula alrededor de modalidades complementarias, los cuales pueden ser inconscientes o conscientes, en donde la presencia de una característica complementaria en una persona impulsa al otro a buscar la particularidad antagónica en su futura pareja, sin que haya puntos de equilibrio o intermedios. En otras palabras, el sujeto buscará en su pareja aquello que no tiene.

Al finalizar el estudio hemos podido concluir que: 1) Existe una elección de pareja más elaborada y orientada a valores y aspectos de la personalidad por encima del físico. 2) Las relaciones de objeto de la infancia fundan las bases para las futuras elecciones de amor. Si bien no se puede generalizar, en esta investigación se evidencia cómo los vínculos tempranos marcan el estilo de relación que se llevará en la adultez. Una relación saludable entre padres e hijos es preventivo para la salud mental de las familias que se construirán. En nuestro estudió en particular ha primado la elección anaclítica, que está orientada a la elección de pareja en base a las figuras parentales de la infancia, en donde uno elige o algo similar a lo conocido o totalmente lo opuesto. 3) La mayoría de nuestros participantes postulan que eligen a su pareja, mientras que una minoría afirma que es algo que no se puede elegir; es decir, que se da de manera circunstancial. Sin embargo, a pesar de ello, se encontró que la elección de todos los participantes estaría orientada en función a las figuras parentales de un modo inconsciente.

Este estudio apunta a la línea de la psicología clínica dentro del campo psicodinámico, en donde aún no hay muchas investigaciones que hayan explorado dicha rama, y dentro de la investigación cualitativa. Es por ello que sugiere que se desarrollen y explore más dentro de dicha corriente.

En cuanto a las limitaciones encontradas en la investigación, hallamos que las características de los sujetos de estudio podrían ser una limitante, principalmente respecto del sesgo psicológico. Esto principalmente, porque se ha podido observar que los participantes, al haber estudiado psicología y ser parte de un proceso largo y profundo de terapia, han logrado identificar y darle un significado mayor a sus 
elecciones de parejas, esto debido a la capacidad de insight que se ha podido lograr en las distintas entrevistas, influidas por las propias elaboraciones que cada participante ha obtenido en sus propios procesos terapéuticos. Así también, consideramos que hubiese enriquecido el estudio poder haber realizado el test proyectivo de la pareja, para poder ampliar y contrastar la historia contada por el participante y lo plasmado en el dibujo.

Por otro lado, pensamos que al hacer el estudio con participantes de otras carreras $\mathrm{y}$ sin un trabajo terapéutico previo los resultados hubiesen variado considerablemente, principalmente por los años y el tipo de terapia, así como la capacidad de insight desarrollada. Por ello, se recomendaría realizar un estudio con participantes de edades menores y sujetos que estudien diversas carreras para ver si otros aspectos salen a relucir, o que otras posturas se repiten en base al proceso de elección.

Para propósitos de este estudio, consideramos que fue importante incluir participantes homosexuales debido que en nuestro país la tolerancia con respecto a esta elección no está siendo del todo aceptada, principalmente por una creencia de que la homosexualidad es una enfermedad. Sin embargo, y a pesar de que aún existen acciones discriminatorias contra las personas homosexuales, se evidencia un cambio cultural que tiende a la inclusión y a la igualdad de derechos; ejemplo de ello es la legalización del matrimonio homosexual que se viene dando en distintos países del mundo (García, 2017). No obstante, los últimos estudios comparativos entre sujetos homosexuales y heteresoxeuales como el de Albornoz (2009), no arrojó diferencias en los componentes del amor y elección de acuerdo a la orientación sexual. En esta misma linea, si bien antiguamente diferentes estudios consideran una diferencia entre ambos sujetos, actualmente no consideramos una diferencia marcada. Estudios como los de Araguez (2012) no encuentran diferencias significativas en cuanto a niveles de bienestar individual o elección en relación con las parejas heterosexuales. Por ello, consideramos que la elección hoy en día para ambos grupos se da bajo los mismos componentes o modalidades: patrones inconscientes infantiles, afinidad de personalidades y libertad de elección. Finalmente, sería interesante realizar un estudio cualitativo profundo y comparativo en participantes homosexuales y heterosexuales para identificar si existe o no, realmente, una diferencia significativa en cuanto al modelo de elección de pareja. 


\section{Capítulo 6. REFERENCIAS}

Alberoni, F. (2008). Lecciones de amor: doscientas respuestas acerca del amor, el sexo y la pasión. Madrid, España: Gedisa.

Albornoz, V. (2009). Relación entre los componentes del amor de la teoría de Sternberg y la felicidad en heterosexuales y hombres homosexuales en una relación de pareja. (Tesis de licenciatura). Universidad de Talca, Chile.

Álvarez-Gayou, J. L. (1996). La sexualidad de la pareja. Ciudad de México, México: Manual Moderno.

Araguez, M. (2012). Parejas homosexuales y heterosexuales en concubinato: Bienestar psicológico y orientación del rol sexual. (Tesis de licenciatura). Universidad Abierta Interamericana, Buenos Aires, Argentina.

Arnett, J. J. (2004). Emerging adulthood: the winding road from late teens through twenties. New York, USA: Oxford University Press.

Auxi, M. (2005). Las huellas del Edipo en la elección de pareja. Asociación Venezolana de Psicoanálisis: VITAE Academia biomédica digital. Caracas, Venezuela.

Barrios, A.; Pinto, B. (2008). El concepto de amor en la pareja. Revista Electrónica de Psicología. Facultad de Psicología, Universidad Católica Boliviana San Pablo. Vol. VI, No ${ }^{\circ}$. La Paz, Bolivia.

Burin, Mabel (1996). Género y psicoanálisis: subjetividades femeninas vulnerables. En Burin \& Bleichmar (comp) "Género, psicoanálisis y subjetividad", Ed. Paidós.

Buss, D. (1994). The evolution of Desire. New York: Harper.

Butler, Judith (2006), Gender trouble. Feminism and the Subversión of Identity, Londres, Routledge.

Calderón, C. (2011). Criterios de calidad en la investigación cualitativa en salud (ICS): Apuntes para un debate necesario. Revista Española de Salud Pública 76 (5), 473-482.

Casullo, M. (2004) Elección de pareja en adolescentes y adultos jóvenes. Psicodebate: Psicología Cultura y sociedad. 4, 39-56.

Coderch, J. (1982). La homosexualidad en los primeros estadios tempranos de la vida. Barcelona, España: Herder.

Coderch, J. (1995). La interpretación en psicoanálisis. Fundamentos y teoría de la técnica. Barcelona, Herder. 
Coderch, J. (2011). Teoría y técnica de la psicoterapia psicoanalítica. Barcelona: Herder.

Coleman, J.C., \& Hendry, L. (1990). The Nature of Adolescence. London: Rothledge.

Cornejo, M., \& Salas, N. (2011). Rigor y calidad metodológicos: un reto a la investigación social cualitativa. Psicoperspectivas: Individuo y sociedad 10 (2), $12-34$.

Craig G. (2001). Desarrollo psicológico. Pearson Educación. México: Universidad Nacional Autónoma de México. Octava Edición.

Craig, G. (1997). Desarrollo psicológico. Ciudad de México, México: Prentice Hall.

Cuevas, A. (2013) "Contexto familiar y elección de pareja: una aproximación a través de madres solas de Colima”, Estudios Sociológicos, Núm. 92, en prensa.

Díaz Loving, R., \& Sánchez Aragón, R. (2004). Psicología del amor: una visión integral de la relación de pareja. Ciudad de México, México: Porrúa.

Fedida, P. (1974). Diccionario de psicoanálisis. Madrid, España: Alianza Editorial,

Flores Galindo, C. (2014). Hegemonía masculina y violencia en relaciones de pareja de mujeres de SJL. Tesis para optar el título de Licenciado en Psicología con mención en Psicología Social. Lima, Perú: Facultad de Psicología, Pontificia Universidad Católica del Perú.

Flores, A. (2003). El noviazgo y otros vínculos afectivos de la juventud mexicana en una sociedad con características postmodernas. Universidad Nacional Autónoma de México: México.

Freud, S. (1912). Nota sobre el concepto de lo inconsciente en psicoanálisis. En Obras completas, tomo XII. Buenos Aires: Amorrortu.

Freud, S. (1914). Introducción al narcisismo. Buenos Aires: Amorrortu.

Freud, S. (1923-1925). El yo y el ello y otras obra. Buenos Aires: Amorrortu.

Freud, S. (1923). La organización genital infantil. Buenos Aires: Amorrortu.

Fromm, E. (1959). El arte de amar. México: Paidós.

Fromm, E. (2000). El arte de amar. Ciudad de México, México: Paidós.

Galimberti, U. (2006). Diccionario de psicología. Siglo XXI de España Editores, S.A.; Edición: 2

García, F., García, C., Hein, H., Hernández, A., Torres, P., Valdebenito, R. y Vera, C. (2017). Relaciones de pareja homosexual y heterosexual: un estudio comparativo. Universidad de Concepción, Chile 
García, J., Garrido, M., y Rodríguez, L. (1993). La formación de la pareja desde modelos psicológicos. En H. de Paz y M. Garrido (Eds.). Formación de la pareja, ritos de casamiento y familia hoy (pp.51-70). Salamanca: Universidad Pontificia de Salamanca.

Garduño, D. (2002). La significación cognoscitiva y las causas que determinan el noviazgo. Tesis de licenciatura. Facultad de Psicología, UNAM.

González Rey, F. L. (2007). Investigación cualitativa y subjetividad: Los procesos de construcción de la información. Santa Fe: McGraw-Hill.

González Rey, F. L. (2007). Investigación cualitativa y subjetividad: Los procesos de construcción de la información. Santa Fe: McGraw-Hill.

Green, A. (1975). The analyst, simbolization and absence in the analytic setting. Int. J. Psychoanal., 56:1-22.

Guerra, G. (2003). La Elección de Pareja. Nueva York: Academia de Ciencias de Nueva York.

Hall, Stuart. (2003). “Introducción: ¿quién necesita “identidad”?. En Hall, Stuart et. al. Cuestiones de identidad cultural. Buenos Aires, Amorrortu

Jayme, M. (2002). La psicología del género en el siglo XXI. Universidad de Barcelona: Barcelona.

Kaufman, M. (1995). Los hombres, el feminismo y las experiencias contradictorias. En M. León, M. Viveros, \& L. Arango, Género e identidad: ensayos sobre lo femenino y lo masculino (págs. 123-146). Santafé de Bogotá, Colombia: Tercer Mundo.

Klein, M. (1932). El Psicoanálisis de Niños. Buenos Aires, Argentina: Editorial Paidos.

Klein, M. (1994). Amor, culpa y reparación. Amor, culpa y reparación y otros trabajos (1921-1945). Obras completas (Vol. I). Barcelona: Paidós (Trabajo original publicado en 1937).

Kristeva J., (2000). El genio femenino. México: Paidós.

Lemaire, J. G., (2013). La pareja humana: su vida, su muerte, su estructura. México: Fondo de cultura Económica.

Libia Castro, B (2008). El amor como concepto filosófico y práctica de la vida. Revista Digital Universitaria. Volumen 9 Número 11 • ISSN: 1067-6079. México DF, México.

Martín García, A.V. (1995). Fundamentación Teórica y Uso de las Historias y Relatos de Vida como técnicas de Investigación en Pedagogía Social. Aula, 7, 41-60. 
Martínez, M. de O., G. (2004). Las historias de amor como método de estudio de la relación de pareja. Tesis de Doctorado. México: Facultad de Psicología de la Universidad Nacional Autónoma de México.

Martínez, P. (2006). El método del estudio de caso: Estrategia metodológica de la investigación científica. Pensamiento y Gestión (ISSN 1657-6276), 165-193.

Maté, C., \& Acarín, N. (2011). Encuesta sobre la elección de pareja a estudiantes de la Universitat Pompeu Fabra, Barcelona (20 a 27 años). Summa Psicológica UST. $8(1), 37-4$.

Medina, J., González-Arratia, N., Valdez, J., López,J. (2007). La elección real e ideal de pareja: un estudio con parejas establecida. Revista Interamericana de Psicología/Interamerican Journal of Psychology - 2007, Vol. 41, Num. 3 pp. 305-311. Guatemala.

Miller, B. C., \& Benson, B. (1999). Romantic and sexual relationship development during adolescence. En W. Furman, B. B. Brown, and C. Feiring (Eds.), The development of romantic relationships in adolescence (pp. 99- 121). New York: Cambridge University Press.

Montoya, T. (2000). Psicopatología de la relación conyugal. Madrid: Díaz de Santos.

Organización Mundial de la Salud (2015). http://www.who.int/es/ Recuperado el 6 de Octubre del 2015, de http:/www.who.int/topics/gender/es/.

Péndola, M. \& Péndola, A. (2014). Temas de psicoterapia psicoanalítica de pareja y familia. Depósito Legal en la Biblioteca Nacional del Perú.

Precht, R. (2011). Amor. Un sentimiento desordenado. Un recorrido a través de la biología, la sociología y la filosofía. Madrid: Siruela.

Quintana, A., y Montgomery, W. (2006). Metodología de Investigación Científica Cualitativa. Psicología: Tópicos de actualidad. Lima: UNMSM.

Rodríguez, R., Gil, J., \& García, E. (1996). Metodología de la investigación cualitativa. Málaga: Ed. Aljibe.

Rolón, G. (2012). Encuentros: El lado B del amor. Buenos Aires: Planeta.

Rubilar,C., Morales, V. y otros. (1995). Ciclo vital y funcionamiento familiar. Seminario para optar al grado de licenciado en Psicología. Concepción: Universidad de Concepción.

Sandler, J., y Sandler, A.M. (1978). Sobre el desarrollo de las relaciones de objeto y afectos. Revista Internacional de Psicoanálisis, 59, 285- 296.

Sandler S. (1993). El paciente y el analista. Buenos Aires, Editorial Paidós. 
Schopenhauer, A. (1999). El amor, las mujeres y la muerte (segunda edición). Ciudad de México, México: Coyoacán.

Scott, J. (1999). El género: una categoría útil para el análisis histórico. En: Sexualidad, género y roles sexuales. Buenos Aires. FCE.

Serrano de Dreifuss, O. (2012). Diagnostico con intervenciones terapéuticas. Psicoterapia breve a partir de la historia. Lima: Universidad Peruana de Ciencias Aplicadas (UPC).

Sferra, A., Wright, M. E., \& Rice, L. (1977). Personalidad y relaciones humanas. México: McGraw-Hill.

Sternberg, R. J. (1989). El triángulo del amor. Intimidad, pasión y compromiso. Barcelona: Paidos Iberica.

Sternberg, R.J. (2000). La experiencia del amor, la evolución de la relación amorosa a lo largo del tiempo. Barcelona: Paidós.

Stoller, R. (1967). El pasaje y el continuo de la identidad sexual En: Homosexualidad en el hombre y la mujer. Buenos Aires: Hormé.

Tordjam, G. (1989). La pareja: realidades, problemas y perspectivas de la vida en común. México, Grijalbo.

Torres, M. (2009). Mujer emprendedora y su Gestión Ética. Revista Cultura. Vol. 23. Lima, Perú. Facultad de Ciencias de la Comunicación, Turismo y Psicología, Universidad de San Martín de Porres.

Tyson, R. (2000). Teorías psicoanalíticas del desarrollo. Publicaciones psicoanalíticas: Lima-Perú.

Uriarte, J. (2007) Autopercepción de la identidad en la transición a la edad adulta. Revista de Psicodidáctica, Universidad del País Vasco: España.

Uriarte, J. (2007) Autopercepción de la identidad en la transición a la edad adulta. Revista de Psicodidáctica, Universidad del País Vasco: España

Valdivieso, S. (2002). El insight en psicoanálisis y sus dimensiones. Rev. chil. neuropsiquiatr. v.40 n.4 Santiago oct. 2002

Vargas, E (2002). Adolescencia, relaciones románticas y actividad sexual. Rev. colomb. psicol., Volumen 11, p. 115-134, 2002. ISSN electrónico 2344-8644. ISSN impreso 0121-5469.

Verdú Delgado, Ana Dolores (2013). "Género y conflicto en las relaciones de pareja heterosexuales: La desigualdad emocional", nº 8, pp. 165-181. 
Warner, K. \& Willis, S. L. (2005). Psicología de la edad adulta y la vejez. Madrid: Pearson Prentice Hall.

Willi, J. (1993). La pareja humana: Relación y conflicto. Ed Morata, SL.L., Madrid.

Willi, J. (2004). Psicología del Amor. Barcelona: Herder

Winch, R.F. (1958). Mate selection. A theory of complementary needs. New York, USA: Harper.

Winch. (1958). The theory of complementary weeds in mate selection. American Sociological Review, Vol.19.

Yela - García, C. (2001). El amor desde la psicología social ni tan libres, ni tan racionales. Madrid: Pirámide. 


\section{Capítulo 7. ANEXOS}

\section{Anexo 1: Consentimiento Informado}

\section{Consentimiento Informado para Participantes de Investigación}

El propósito de esta ficha de consentimiento es proveer a los participantes en esta investigación con una clara explicación de la naturaleza de la misma, así como de su rol en ella como participantes.

La presente investigación es conducida por Andrés Anteparra y Romina Dasso, alumnos de la carrera de psicología de la Universidad Peruana de Ciencias Aplicadas. El objetivo de este estudio es "comprender el proceso de elección de pareja en participantes que hayan sido parte de un proceso de corte psicodinámico".

Si usted accede a participar en este estudio, se le pedirá responder algunas preguntas en una sola reunión, de aproximadamente 45-60 minutos. Lo que conversemos durante esta sesión se grabará, de modo que los investigadores puedan transcribir después las ideas que usted haya expresado. La participación es este estudio es estrictamente voluntaria. La información que se recoja será confidencial y no se usará para ningún otro propósito fuera de los de esta investigación. Sus respuestas a las conversaciones serán codificadas usando un número de identificación y por lo tanto, serán anónimas. Una vez trascritas las entrevistas, las grabaciones serán borradas. Si tiene alguna duda sobre este proyecto, puede hacer preguntas en cualquier momento durante su participación en el. Igualmente, puede retirarse del proyecto en cualquier momento sin que eso lo perjudique en ninguna forma. Si alguna de las preguntas durante la entrevista le parecen incómodas, tiene usted el derecho de hacérselo saber al investigador o de no responderlas.

Reconozco que la información que yo provea en el curso de esta investigación es estrictamente confidencial y no será usada para ningún otro propósito fuera de los de este estudio sin mi consentimiento. He sido informado de que puedo hacer preguntas sobre el proyecto en cualquier momento y que puedo retirarme del mismo cuando así lo decida, sin que esto acarree perjuicio alguno para mi persona. He sido informado (a) de las condiciones en las cuales acepto colaborar de manera voluntaria con la entrevista realizada por el (la) alumno (a): el día 


\section{Anexo 2: Ficha Sociodemográfica}

FICHA SOCIODEMOGRÁFICA

NOMBRE (SE UTILIZARÁ SEUDÓNIMO):

SEXO:

EDAD:

ESTUDIOS:

ESTADO CIVIL:

HIJOS:

PAREJA ACTUAL:

TIEMPO DE PERMANENCIA EN TERAPIA DE CORTE PSICOANALÍTICA:

FIRMA DEL PARTICIPANTE 


\section{Anexo 3: Guía de preguntas}

En primer lugar, se pretende explorar aspectos de la vida del participante. Por lo que se utiliza la siguiente consigna: Cuéntame un poco sobre tu infancia. En segundo lugar, se pretende explorar cada eje propuesto en la presente investigación con las siguientes preguntas:

\section{Aspectos Conscientes:}

- ¿Cómo eliges a tu pareja?

- ¿Qué aspectos - conscientes- consideras al momento de elegir una pareja?

- ¿Qué es lo que ya no buscas en tu pareja?

\section{Aspectos Inconscientes:}

- ¿Qué aspectos - inconscientes - ha identificado con su terapeuta respecto de su elección?

- ¿Qué patrones crees que se han repetido en tus distintas elecciones?

- ¿Qué similitudes encuentras con tu padre o madre o algún referente en tu familia en cuánto a las parejas que has tenido?

\section{Construcción Personal:}

- ¿Qué es elección de pareja para ti? 


\section{Anexo 4: Transcripción de Entrevistas}

\section{Participante 1: Daniel}

\section{E: Cuéntame Daniel, ¿A qué te dedicas?}

D: Ahorita estoy sin chamba, de hecho estoy avocado en titularme, entonces lo he dejado en "stand by", pero mi internado lo hice el año pasado en Arie.

\section{E: ¿Y cómo fue tu experiencia en Arie?}

D: Monótona. No te voy a negar que aprendí mucho en cuanto a temas del desarrollo en niños, prevención y terapia, pero el trabajo con niños siempre es más tedioso... Y sentía que por el hecho de que era remunerado nos explotaban más, que a diferencia de otros centros sobre todo cuando haces tu internado en clínica y no te pagan.

\section{E: Entonces estas más interesado en... (Toma la palabra él).}

D: Creo que aún no estoy seguro, a pesar de que ya me gradué, uno sigue descubriendo poco a poco su rubro, su camino, pero de hecho sí estoy interesado en hacer psicoterapia, en niños no (entre risas), pero con adolescentes, adultos, sí me interesa. De hecho pienso buscar la experiencia cuando termine de titularme. Igual no me cierro a probar lo que venga, cuánta más experiencia mejor, aunque con niños ya no más. He estado en recursos humanos, en elección de personal y me parece un campo interesante... Uno puede tener diversas pasiones, pero nunca debe cerrarse a algo, más bien disfrutar el proceso.

\section{E: Y bueno, cuéntame un poco sobre ti, sobre tu infancia}

D: Mi infancia, bueno un poco rara, o no sé si rara. Tengo dos hermanos, yo soy el tercero. De hecho ellos siempre han destacado muchísimo. Uno es ingeniero de software y trabaja en una empresa top en Holanda. Justo estuve por ahí, porque se casó hace un mes con una holandesa y aproveche en conocer otros países cerca. Europa es de otro mundo, nos falta mucho a nosotros como sociedad, abrir nuestras mentes, pero sobre todo respetar al otro. Acá todo el mundo hace lo que quiere, cuando quiere, y sin pensar en el otro... Pero bueno, para eso estamos nosotros también ¿no? Para tratar de ayudar, de cuestionar, y hacer mejores personas o seres humanos. En fin, mi otro hermano es ingeniero industrial, y siempre era el que sacaba mejores notas o destaca más que yo desde el colegio. De hecho es con el que menos tiempo me llevo, él tiene 26, yo 24, y Andrés que es el mayor 29. Entonces en casa yo era como "la oveja negra", el idealista, el que iba a estudiar psicología en una familia de ingenieros o cerebritos. Mi mamá de 
hecho siempre me apoyó, pero yo siempre sentí que mi viejo no me iba a dar mucha bola con mi carrera y así fue. Igual me he ido demostrando lo hábil que soy o lo bueno que puedo llegar a ser cuando me gusta, me apasiona, de hecho también se lo he ido demostrando a él.

\section{E: ¿Y cómo te sientes con eso?}

D: Bien, de hecho muy bien. No sé si yo me la termine creyendo en cierta parte que no iba a poder o no iba a destacar, ya que si tienes dos hermanos que siempre sobresalen y tú no tanto, y tu viejo de vez en cuando te lanza estos comentarios de "mira a tus hermanos como pueden, ¿acaso tú no vas a poder"? o "mira las notas de Raúl”, como que no es que te sientas menos, pero ya existe una pre - desventaja, y es como que si estuvieras en un nivel menos. Y a veces no sabía lo que mi mamá pensaba de todo esto, porque a veces sólo estaba ahí parada, sin decir nada...

Igual casi al primer año que yo entro a la universidad, mis papas se separan. Es que en realidad nunca llegue a entender su relación o a verlos como tal. Ellos guardaban mucho ese vínculo entre cuatro paredes. No tengo algún recuerdo de ver a mi papá dándole un beso a mi mamá o diciéndole algo de amor. Eso es raro ¿no?

\section{E: ¿Cómo raro?}

D: No sé, yo cuando iba a la casa de mis amigos, ponte después del colegio, veía muchas veces cuando el papá llegaba, abrazaba a su esposa, la saludaba o le decía ciertas palabras que uno asumía que eran pareja. En mi caso yo veía siempre una amistad, no tanto una relación.

\section{E: ¿Y tú como eliges una pareja?}

D: Definitivamente no como la que tuvieron mis papas (entre risas). Es que él es bien frio, le cuesta expresar lo que siente, mi mamá no tanto, de hecho yo he sido el más pegado a mi mamá, con sus cosas, porque tiene un carácter bien fuerte, siendo a veces algo agresiva, retadora, pero siempre me cuidaba. Mmm... yo elijo no sé, me atrae la inteligencia, incluso que se vean un poco "nerd", con los lentes, pero que sean ellas, auténticas. Alguien que te apoye, que este contigo, pero tú también puedas hacer lo mismo con ella, ósea que esto sea complementario. Creo que se forman por el hecho de que son un equipo, el tema de hablar, de no guardarse las cosas y tratar de solucionarlo juntos, eso me gusta y creo que busco.

\section{E: ¿Identificas aspectos conscientes que son indispensables o que consideras al momento de elegir una pareja?}


D: Sí, el tema de que tengan un problema, ayudarlas... Es como si alguien que está contigo se apoya en ti, a pesar de la carga, la locura, o los problemas que van ya con ella, que están dentro de ella, ella sabe que se puede apoyar en ti. Racionalmente, una chica que tenga mi misma mentalidad, que sea buena y que me tranquilice. Una persona cariñosa, que no haya experimentado mucho sexualmente. En lo físico, que me genere una sensación de dulzura, que sea linda. La personalidad es la parte más importante, porque te puede enamorar bastante. $\mathrm{Y}$ bueno, tiene que ser una persona con mucho humor. También tendría que tener algún problema que yo pueda solucionar, porque siempre me atraen más las mujeres que tienen un problema o no se sienten bien por algo, entonces yo trato de hacer que solucionen "eso". He sido consciente de esto hace poco, en retrospectiva: que muchas de mis salientes o parejas siempre pasan por algún problema. Que yo pueda ayudar me atrae mucho... También que sea una chica que no se deje llevar por externalidades, por la sociedad, poco común: una mujer independiente. Una persona que pueda ser capaz de tener su espacio, aunque por más de que a mí me va a costar, porque yo no soy así... En realidad quiero ser autosuficiente.

\section{E: ¿Cómo así autosuficiente?}

D: Yo lo sé, lo he asumido, soy una persona dependiente de mis parejas, y lo asumo como tal, pero también estoy tratando de desligarme de eso, de también tener mi espacio, de separarme de ellas. Antes no lo veía mal, pero de hecho con mi última pareja termine siendo muy invasivo, también por sentir que su familia no la ayudaba con la depresión, entonces fácil en un momento confundí roles o asumí aspectos que no me correspondían de ella. Lo sé, y sé que hice mal. Por algo ya no estamos juntos también.

\section{E: ¿Y qué aspectos inconscientes has identificado en tu elección?}

$\mathrm{D}$ : Mmm he tenido dos relaciones serias, y de hecho con la primera fue todo muy superficial, sentía que el tema de la religión nos unía. Yo era súper religioso en cuanto a cumplir con ciertos patrones que por ser parte de alguna iglesia uno debe de ejercer, respetar, además de venir de un colegio religioso, y con una mamá recontra castrante, no sé, que te inculca ello, pero de ahí pasa el tiempo, te rebelas, y ya buscabas tú creer en lo que quieras, tu propia identidad... Es como si hubiese buscado, como con mi última ex, mujeres más maternales, tiernas, contenedoras, que cuiden. De hecho ambas tenían carreras serviciales, una era nutricionista, la otra es doctora, cuidan ciertos aspectos, ¿no? No estoy diciendo que buscaba a una mamá, pero si alguien con ciertos rasgos que van en sintonía. 


\section{E: ¿Qué patrones crees que se han repetido en tus distintas elecciones?}

D: Mmm, como lo que te acabo de decir, este rol de protección, y el que tengan un problema. Sí, el que se apoyen en mí y yo también poder hacerlo con ellas. Que sea dual.

\section{E: ¿Qué similitudes encuentras con alguno de tus padres o algún referente en tu familia en cuánto a las parejas que has tenido?}

D: De hecho que en ambos, porque por parte de mi papá, él siempre ha sido distante conmigo, pero igual me daba cariño, a su manera, porque en cuanto a demostraciones casi nada, pero de decírtelo sí, y eso lo he identificado en mis parejas... En el sentido de que yo soy súper ansioso, y cuando me venían ciertas crisis, era difícil que alguien me contenga, por lo mismo que estaba en crisis, pero cuando ésta acababa, se calmaba todo, ya podía ser contenido. Es difícil también compartir con alguien que es ansioso como yo, y enfrentar estas crisis. Hay personas que se asustan, y tu pareja, a veces no saber cómo enfrentarlo o como ayudar... También tengo mis crisis de inseguridad, de sentirme bajoneado, de no sentirme cómodo conmigo mismo, y si no está esa persona para levantarme como que me quedo en eso, me pierdo...Creo que soy algo complicado, por eso elijo a chicas con problemas, para poder salvarlas y que ellas le salven a mí, creo (risas). Con mi mamá te lo comente, el carácter fuerte, agresivo, retador. Mi ex cuando se trata de ella en rol de médico, es una mujer súper fuerte, retadora, que sabe a lo que va, de hecho fue la primera en su facultad, en la Cayetano, no es cualquier cosa...Súper inteligente, pero también tiene ese lado más tierno... Bueno el problema es que ella es depresiva, diagnosticada y con pepas, y lógico eso la llevaba a tener unos bajones bien profundos, pero sólo veía al psiquiatra y cada cierto tiempo, su familia no quería que viera a la par a un psicólogo, o vio por un tiempo a uno, pero que era cercano a la familia, como su tía lejana, entonces nada que ver... había que ayudarla a salir de eso, y su familia no la apoyaba, ósea sí, pero tapaba el problema como te comente.

\section{E: Daniel, para terminar: ¿Que es elección de pareja para ti?}

D: Uno elige, lo busca, definitivamente es una elección. Hay procesos más cortos, más largos, pero finalmente es una elección. El hecho de que pase es que has hecho una elección, en base a expectativas, a un "checklist", en base a aspiraciones, a ciertos requisitos, o simplemente porque es una persona sexual, pasional, que te atrae de tal modo. Y es natural, lo demás se da. 


\section{Participante 2: Lucía}

\section{R: Cuéntame Lucía, ¿A qué te dedicas?}

L: Ahorita soy profesora para niños en la compañía de teatro, circo y música, en niños de $3-6$ años. Además de eso soy acompañante terapéutica de un niño de un nido, que tiene ciertas dificultades de aprendizaje.

\section{R: ¿Cuándo te graduaste?}

L: En mayo del año pasado, aún estoy en el proceso de titularme.

\section{R: Me gustaría saber un poco de ti, sobre tu infancia.}

L: ¿De mi infancia en general? Con mi familia siempre he viajado mucho, campamentos así, bravazo. He estado siempre en contacto con el arte, con el circo en particular, en la compañía de teatro, circo y música del Perú empecé a los 4 , luego después de un tiempo salí un rato, estudie, y luego he vuelto ahora enseñando. Mi familia es bien chiquita, yo soy más pegada a la familia de mi mama, mi papa falleció cuando yo tenía 5 años. Hasta antes que el falleció éramos todos unidos, pero cuando murió luego el contacto se volvió más formal. En verdad también hemos sido de generar familias alternas. Porque la familia de mi mamá se fue al extranjero a vivir, y hemos tenido así como que primos de cariño, amigos, así. Siento que tuve una infancia bastante feliz.

\section{R: Cuéntame, ¿Cuántos hermanos tienes?}

L: Un hermano mayor, 4 años más que yo.

\section{R: Y qué tal, ¿Cómo te llevas con él?}

L: Cuando éramos chicos... Bueno, siempre nos hemos llevado relativamente bien. Igual como cualquier hermano siempre hay peleas. Aparte a raíz de lo de mi papá, los tres nos juntamos mucho más. Siempre hemos hecho todo juntos - mama, hermano y yo - todo juntos. No sé, comer juntos, ver tele, así espontáneamente. Y bueno, cuando éramos bien chicos, hacíamos "covachas" en el cuarto. Ya cuando estábamos en el periodo de adolescencia, primero lo suyo, y luego lo mío, ahí si fue medio "thriller".

\section{R: ¿Cómo así?}

L: No tanto como que chocábamos mucho, pero éramos bien diferentes en temperamentos. Yo siempre he sido bien sociable, entradora, alegre, no sé. Él es más introvertido, a veces tiene un temperamento fuerte, era medio "emo". Y bueno, yo en la casa con mis amigas metida ahí, el me odiaba (ríe). Pero ya después, cuando pasaron los años, yo ya tenía 17-18 años, salí del cole y ya cambias... Empezamos a parar juntos inclusive. Él se hizo muy amigo de mis amigas de la universidad, y como siempre invitaba gente a la casa él se unía. 


\section{$R:$ ¿Y con tu mama?}

L: Tenemos una relación súper linda... Es, ósea ella, a raíz de lo de mi papá ella siempre ha sido un súper, súper sostén para mí, no solo eso, tenemos una relación de mucha confianza, puedo hablar con ella de diferentes cosas... Las típicas que te pasan cosas en el colegio, y no hablas con tus papas, bueno yo siempre hablaba con ella. Además de hecho el ser tan cercanas, hace que no choquemos, y de hecho siempre hemos funcionado como una casa bien democrática, pero a veces mi mama tiene que bajarnos los humos. A mí porque soy un poco acelerada - ríe -.

\section{R: ¿Democrática cómo?}

L: En general para cualquier cosa, cosas desde vender el carro o no. Mi mamá siempre ha sido bien respetuosa con las cosas que dejo mi papa, el elegir donde pasar navidad, que hacer, etc. Siempre le ha gustado contar con nosotros. Pro a veces me costaba ubicarme en mi lugar de hija, y medio que chocábamos. Porque ella es más parecida al temperamento de mi hermano, y yo más al de mi papá. Igual ella siempre me ha apoyado en todo lo que he querido hacer.

\section{R: Tu papá era igual a ti... ¿Eso te acuerdas o te han contado?}

L: Me acuerdo y me han contado. Ósea como que mi papa era el típico, de ¡vamos de campamento! Y no éramos solo nosotros, sino que invitaba a más gente y así como yo. Y claro, eso también tiene sus implicancia, porque el ya no está, y para mi mama era difícil porque el ya no está, hacía falta tener esa otra perspectiva, verme crecer y verme muy parecida a él. Y ahora que lo vemos con más madures las dos, lo hemos resuelto naturalmente. En general creo que tenemos una muy buena relación.

\section{R: Y cuéntame Lucía, ¿Cómo eliges a tu pareja?}

L: No sé si la elijo. Lo que pasa es que yo he tenido dos relaciones importantes a lo largo de mi vida. El primero fue un chico con el que estuve cuando tenía 15, duró 5 años, entonces básicamente me gustaba ese chico, no lo conocía tanto y me dijo ¿quieres estar conmigo?, en Bembos, y bueno así fue no más. Wow, fue un montón.

\section{R: ¿Cómo se conocieron?}

L: Fue una relación muy bonita, nos conocimos en el ovalo Gutiérrez y él era amigo de una amiga mía. Y en verdad nos vimos poquísimo, éramos unos chibolos, y salimos como que una vez solos y ya de la nada estábamos. Tenía 15 y el 16, y nadie pensaba ni yo ni nadie que la relación iba durar tanto. Él es de una familia judía, y después de un tiempo eso empezó a pesar un poco. No con su familia, pero si con la comunidad. Porque la comunidad le pagaba después la U y la comunidad le ponían ciertas 
condiciones. Y como ya íbamos creciendo, empezamos chibolos y ya de ahí éramos personas grandes mientras estábamos juntos, entonces íbamos creciendo para lugares diferentes.

\section{R: ¿Y cómo era la relación?}

L: Él es un súper buen chico, los primeros dos años fue una relación muy bonita. Estábamos en el cole, y la vida no había cambiado mucho. Ya yo en la U, las coas fueron cambiando. Él era bien cerrado con sus amistades, le costaba hacer amigos, y bueno yo era distinta. Empecé a conocer gente nueva, y a él le costaba integrarse. Sentía que no tenía la posibilidad de llevarlo a reuniones porque nunca quería. Además había presiones externas de que la relación no iba a funcionar. Yo entendía que él tenía que estudiar por que la comunidad le pagaba los estudios, pero se le notaba una cara de él bastante tibia en cuanto a sus prioridades. Pero luego sus papas le dijeron que iban a tratar de asumir el pago económico para liberar un poco la presión de la comunidad. Por qué no querían que el este como que amenazado por "algo". Cuando pasó eso pensamos, buenazo ahora si vamos a poder estar bien sin presiones externas, pero luego de 10 meses terminamos. Entonces no era solo las presiones si no tal vez nosotros mismos.

\section{R: ¿Y cómo fue esta separación?}

L: Yo terminé con el por qué el nunca termino conmigo, pero creo que él también quería terminar conmigo -ríe-. Era lo mejor para los dos. Fue doloroso igual, por el tiempo que estuvimos pero ya no era. Fue difícil aceptar que habíamos cambiado en estos 5 años y que las cosas ya no eran. Porque no sé si te ha pasado eso que la relación es más grande que la pareja, porque todos te dicen que lindos son juntos, que empezaron desde tan chicos y seguro se casan, pero tuvimos que aceptar que habíamos cambiado. Igual como te dije, fue una relación muy linda, muy buena.

\section{R: ¿Y qué valorabas de él?}

L: Él es un chico muy generoso con su tiempo, con su persona, siempre dispuesta a estar en los mejores y en los peores momentos. Siendo un chibolo, me toco perder familiares cercanas, y él era súper estable en esos momentos. Fue un gran apoyo, siempre estuvo ahí a pesar de estas situaciones densas. Además tenía esto que me gustaba, que nos divertíamos juntos, descubríamos parte de nuestras vidas juntas, era rico pasar de una relación de chibolos a una más grande. Ayudarnos en decisiones de carreras, nuestros planes, que hacer, etc. Compartimos eso y nos fue muy bien a pesar de no querer lo mismo. Él siempre quiso ser médico y yo lo apoyaba en todo este 
procesos de estudiar, amanecidas, etc que tienen los médicos. Siempre estuvimos uno por el otro... Pero la verdad, ahora miro para atrás y digo porque estuve tanto tiempo con este chico - ríe -

\section{R: ¿Y por qué eso? ¿Cómo una relación de amistad?}

L: Si, creo que sí... Al principio me costó mucho despegarme de él como amigo, como persona en mi vida... porque claro pues, fue más un compañero. Y si bien a mí me encanta esta nota de salir y vacilar, yo nunca he querido esas relaciones momentáneas. Nunca se me ha visto así, entonces he salido con poca gente.

\section{R: ¿Y que no te gustaba tanto de él?}

L: Uy, el tema social... Hacer vínculos con gente que yo conocía, amigos míos. Estaba siempre como un tronco, no se esforzaba por ser amigo de mis amigos. Luego me di cuenta que le incomoda el círculo donde yo me movía, donde yo trabajaba. Básicamente, porque yo empecé de muy chica a trabajar en la compañía de arte, y su onda era negativa hacia mi chamba. Era cero apoyo en relación si yo quería descansar, y si no podía salir él se molestaba, y a mí me daba mucho que pensar porque yo trabajo porque me hace feliz, me da independencia, y a veces tenía que trabajar los sábados. Era súper inmaduro en relación al trabajo.

Luego también, algo que quizás es más mío, yo empecé a sentir que no había intensidad en la relación. Que él no me quería tanto, o en todo caso no me quería como yo quería que me quieran. Todo muy plano, siempre todo muy bien.

\section{R: ¿Era como costumbre?}

L: Ósea, la costumbre siempre va llegar en una relación, pero uno tiene que saber manejarla. Pero yo creo que en este caso ya nos habíamos vuelto amigos, tal vez mi mejor amigo. Y tal vez no - ríe - porque quizás hubiese fluido mejor, no sé. Pero me daba cuenta de eso, y me hacía mucho daño eso porque yo si soy más intensa. Y bueno, eso era una constante en la relación.

\section{R: ¿Y tu pareja actual?}

L: Miguel, bueno a él lo conozco hace miles de años pero no éramos amigos. Nos conocimos formalmente en la cato, es un año mayor que yo (publicista). Pero yo sabía de él desde la época de la confirma, lo veía en la Universidad pero éramos conocidos. Pero él era bien amigo de amigas mías de psicología. Y bueno, en mi último año de Universidad, que iba dos veces por semana, ahí nos vimos en Toro como un par de veces por amigos en común y no se a mí me gusto, siempre me había parecido un chico interesante y ese día estaba media picada y me acerque y fuimos hablando. Y luego 
siempre aparecía en todos los sitios donde yo estaba - ríe - supongo que porque era amigo de mis amigos... Y bueno fue fluyendo salir los dos solo, planes tranquis, y emperezamos a salir como por 1.5 meses, yo pensaba que me estaba "friendzoneando" ríe - pero lo tomaba como venía, o ya tenía un tiempo sola y de hecho ya había salido con patas pero nadie me había movido como el hasta ese momento. Además la forma y salir así como hacíamos era locazo, y me gustaba esa calma con la que se inició todo y luego un día él se iba de viaje, y antes de eso chapamos y a partir de ahí se volvió todo mucho más serio. Y salimos un par de meses más así, y luego ya formalizamos pues ríe - Fue bonito porque nos fuimos enamorando solos.

\section{$R:$ ¿Y cómo crees que lo elegiste?}

L: En verdad no sé cómo lo elegí, en todo el proceso de conocernos lo sentí tan honesto y tranquilo en su nota que me gusto, me gusto salir con un chico que me hablara de cosas que para mí eran importantes, con tanta libertad. Y yo tengo esto del feminismo, la homofobia bien abierta, y Miguel es igual, entonces teníamos esto del "no estereotipo" y me gustaba que el fuera tan libre en ese sentido. Y además que es un chico que siempre ha hecho su vida "a su voluntad"

\section{R: ¿A su voluntad cómo?}

L: Desde chibolo el por ejemplo, sus papas son de provincia, y él tenía una infancia bastante tradicional. Pero él y su hermana, cada uno es más loco el otro, y bueno no se ponte a los 17 a Miguel se le ocurrió hacerse un piercing y su papa lo vio y le cerro el caño, y el recién estaba en primer año de $U$, y el alto que fue a trabajar a algún bar. Y cosas como esas no, se la busca siempre de acuerdo a lo que él quiere.

\section{R: Entonces de manera consciente, ¿qué aspectos consideras tú en tu elección de pareja?}

L: Me tengo que morir de risa, no quiero estar con alguien que no pueda hacer eso. Y con miguel es así, podemos estar chorreando viendo "netflix" y la pasamos increíble. Eso para mí es súper importante, porque mi referente previo era ser "plano". Eso por un lado, por otro lado es importante sentir que me respeten y valoren por quien soy y yo igual, sin necesidad de alterar nada del otro. Que es con lo que me topé con gente que iba conociendo, y tenían un molde en la cabeza, muy marcado, porque eso no me gustaba. Y con Miguel somos como que libres, esta es tu vida y esta es tuya, pero tenemos puentes para estar juntos. Por ejemplo, cuando recién estábamos él se fue a Argentina por varios meses, y fue súper tranqui, no nos limitamos, respetamos lo que quiere cada uno. 


\section{R: ¿Encuentras alguna similitud entre estas parejas que mencionas?}

L: - ríe - El nombre, es una cosa complicadísima. Miguel - Daniel, se parecen en algo pues y la gente los confunde horrible. Son nombres bíblicos - ríe -.

\section{R: ¿Y en personalidad?}

L: Mmmm tal vez miguel no es tan cerrado, pero si es una persona más tranquila. Yo soy más entradora, él no. Y en ese sentido es más reservado, en su grupo de amigos, y bueno eso también es medio parecido a Daniel. Más a la introvertidos quizás. Igual Miguel no es resistente a conocer gente nueva como era Daniel. Puede no ser el alma de la fiesta, pero está ahí y eso es chévere pues. En verdad no son parecidos, más bien son opuestos.

\section{R: ¿Y qué aspectos inconscientes has encontrado?}

L: De hecho yo he visto que la relación con Daniel, fue un poco más en temas de estabilidad. La pérdida de mi papa tan chica, fue difícil de tramitar, y no percibía la muerte como muerte, y la he tenido que resignificar varias veces. Y bueno lo que conversaba con mi terapeuta, es que Daniel fue un hombre en mi vida estable, y eso me atraía mucho. Quizás más la estabilidad que él me daba que el mismo. Porque mi papá se fue muy pronto, y era algo que necesitaba. Pero también como te comenté, cuando tuve varias perdidas de familiares cercanas, y Daniel y yo teníamos ya 3 años, tuve un duelo bien fuerte por mi abuela, fue súper difícil.. Y la presencia de Daniel fue vital como apoyo. El representó estabilidad, y él estaba dispuesto a siempre estar ahí. En Miguel, bueno, antes de estar con Miguel yo salí con dos o 3 chicos que si los contaría. Con el primero fue un chico que estaba en mi chamba que me gileaba desde antes de terminar inclusive de Daniel. Y bueno después de vacilarme, salí con un chico que estaba metido en su publicidad... Salí con un chico súper aventurero, tenía su jeep, y de momento a otro como lo conocí, que fue al final de un tono, así de un día a otro se desapareció. Porque de hecho me chocó horrible, y yo no entendía por qué, y la gente me decía que él se moría por mí, súper intenso, y yo estaba bien afanada, pero me quede estúpida. $\mathrm{Y}$ en ese momento, en terapia, pensé que cosas me movieron tanto, y estas cosas eran cosas que yo quería recuperar, cosas de mi papá, que cuando él se fue se fueron también, y en este chico habían esas cosas, que no las veía hasta que el también desapareció. Y eso me lo mostró clarito, era igual a mi papá. Y bueno, eso me hizo darme cuenta que yo tenía que estar atenta a no reemplazar cosas por cosas que no era. Hice muy consciente y presente que no me tenía que meter con nadie que yo tenía que exigirle más de lo que podía darme. Y bueno, después vino Miguel, que también es 
artista, creativo, y cosas que yo valoro mucho porque mi papá era también artista un loquillo, y son esas cosas que a mí me jalan mucho. Nunca me vería, así nunca, con un ingeniero pues - ríe -

Igual todo esto me hizo darme cuenta que no tenía que cargar al otro con mis temas, porque sin querer lo hacemos, quizás inconsciente, terminas por agobiar la relación por cosas que no corresponden. Pero ahora sigue siendo la estabilidad de la figura masculina muy importante. Inclusive con Miguel, los dos somos mega intensos y cuando peleamos igual tratamos de estar tranquilos, de mantenernos, podemos gritar y todo pero sabemos que todo tiene que ir tranquilo. Y lo hemos hablado, y bueno el hizo algo, que no ha hecho nadie nunca.. Acompañarme a este lugar donde fue el accidente de mi papá, estuvimos ahí limpiando la escultura donde pasó, y fue un momento locazo y lindo. Pensaba y ahora como m saco esto - ríe - Compartí con él un cierre mío, y Miguel de alguna manera se enamoró de ese lugar y estuvo súper dispuesto a acompañarme y hacer ese cierre.

\section{R: ¿Y has encontrado similitud alguna con tu mamá en tus relaciones?}

L: Con mi mamá el tema eterno es que es muy exigente. Conmigo, con ella, mi hermano. No en términos de notas o rendimiento, sino en cómo y quién eres como persona. Y así como es conmigo, es más exigente con mis parejas y amigos. Cuando algo no le cierra me dice, así sutil, pero me lo dice - rie - Y esas cosas con ella son difíciles. Con Daniel se encariño porque fue desde chicos y todo. Con Miguel fue más difícil porque ella no entendía por qué íbamos de viaje, salíamos y no estábamos, y todo eso le costó. También le costó vincularse con él, aunque ahora es más chévere y mi mamá ya entiende que es un buen chico. Y pues yo, soy súper exigente - ríe - Lo he tenido que aceptar. Entonces claro tengo que dar un paso atrás y decir tranqui "eres tú que eres una pesada, no es tan grave”. Es un ejercicio para mí separarme de esa exigencia para llevar la fiesta en paz.

La relación con mi mama ha sido mega cercana y estable, y ese vínculo me ha permitido tener facilidad de vincularme de manera más saludable con los demás. Siento que gracias a eso mi relación con Miguel es demasiado saludable.

\section{R: ¿Y encuentras alguna similitud en que se parezcan tu mamá y tu pareja actual?}

L: Mmm, sí (ríe). Los dos son géminis. Por ejemplo ambos son personas reservadas, no necesariamente conmigo, pero no van por ahí contando sus problemas al mundo, valoran su privacidad. Igual mi hermano, por eso Miguel y mi hermano se llevan súper bien. Y bueno, por como son mi mamá y miguel en ese sentido creo que les costó 
empezar a conectar. Y son también, bueno en mi familia todos son fotógrafos, y hay un tema visual.. Es difícil de explicar, pero como un psicólogo el fotógrafo son súper observadores, y tienen diferentes encuadres de ver la vida.. Y Miguel al ser un loco es súper observador y te saca con esas cosas. Y ambos son así calmados y me ayudan y me siento contenida.

\section{R: ¿Te acuerdas del vínculo que mantenían tus papas?}

L: La verdad que no me acuerdo mucho de su relación de pareja... No tengo recuerdos de peleas y nada de esas cosas entre ellos. Tengo recuerdos de ellos en diferentes situaciones. Una anécdota más de mi hermano, estaba mi abuela conversando con una tía... Y como que mi tía preguntaba qué pena charito se separaron, y mi hermano súper tranquilo dice "bueno pero mejor", y él tenía como 8 años.. Y todos como "que" y el sí pues mejor, porque a veces se peleaban pues y bueno ahora así mejor. Porque mi hermano si se acuerda que a veces cuando se peleaban mi mama se iba a dormir a nuestro cuarto, porque nosotros dormíamos juntos. Igual mi papa siempre fue muy considerado con mi mama en todo, se separaron pero mi papa siempre estuvo pendiente de nosotros y nunca nos faltó nada. Fueron felices el tiempo que estuvieron juntos, y bueno no funcionó. Aunque quizás era solo una época que tenía que pasar, porque mi papá quería volver con ella pero pasó el accidente.

\section{R: Para finalizar, Lucía, ¿Que es elección de pareja para ti?}

L: Yo no sé si es elección, en mi experiencia que también soy media romántica. Y con Miguel, siento que... bueno no te voy a decir que hay una media naranja, pero sí creo que la vida te pone en el lugar donde tienes que estar para encontrarte con la gente que tienes que encontrarte. Y lo que sí creo que hay es una construcción de la pareja, cuando uno ya está ahí metido. 


\section{Participante 3: Oscar}

E: Oscar, cuéntame: ¿Cuántos años tienes?

O: Tengo 25

E: ¿Cuándo te recibiste?

O: Termine la carrera y el internado en diciembre del 2014 y me gradué en el 2015

E: ¿Actualmente a qué te dedicas?

O: Estoy llevando cursos de formación en un centro psicoanalítico, y a la par teniendo experiencia con pacientes.

\section{$\mathrm{E}:$ ¿Te interesa la psicoterapia?}

O: Sí, claro. De hecho es mi primera experiencia como tal, porque cuando hice mi internado sólo me mandaban a aplicar pruebas y hacer informes (entre risas), que de hecho si tenía cierto acercamiento hacia el paciente, pero no la experiencia como tal. Ahora estoy llevando un curso de técnica psicoanalítica, en donde leemos y hablamos desde el origen de esta, hasta aspectos como la importancia del silencio en sesión, los tipos del silencio, no sólo del paciente si no del terapeuta, ya viendo aspectos más profundos que de hecho en la universidad todo pasa tan rápido o no se llega a profundizar, que es interesante cuando estas tu solo buscando herramientas que te gustan a ti, y que de hecho te van a sumar para tu formación.

\section{E: Entiendo... Oscar cuéntame un poco sobre ti, sobre tu infancia}

O: Sobre mí, bueno vivo con mis papas, mi hermana se casó el año pasado, ella tiene 30 , y por ende ya no vive con nosotros, pero de hecho nos juntamos todos los domingos, o al menos eso tratamos. Con mi hermana, siento que nunca fui cercano a ella, no porque sucedió algo específico, sino porque así se dio. Tengo vagos recuerdos juntos de niños, no sé si la diferencia de edad afectó, pero así se dio. Actualmente sí es distinto, pero cuando lo relaciono con la infancia sí es otra historia... La relación ahora es más íntima por así decirlo, en donde yo le comencé a contar sobre las chicas con las que salía y ella me escuchaba, o me daba su percepción de ciertas cosas, y de hecho hemos compartido yo con mi pareja y ella con su esposo ciertos planes tipo comidas, cine y esas cosas. Hay relaciones de hermanos que se pueden dar post adolescencia, o algo así, no estoy seguro de cómo llamarlo, pero sí, a veces las cosas suceden de otra manera. Pero más vale tarde que nunca, ella es muy genial. En cuanto a mis papás, mi papá siempre fue el que exigía en casa en cuanto a notas, decidir qué estudiar, en buscar el primer trabajo, pero a pesar de haber sido siempre exigente, también era atento $\mathrm{y}$ preocupado, a su manera, pero lo era. Era también el que buscaba hacer planes distintos, 
tipo acampar en la playa, hacer un picknick en el jardín de la casa, en ese aspecto siempre ha sido espontaneo. Con mi mamá, ella siempre ha sido mi cómplice, porque antes de yo conversar con alguien sobre algo, lo conversaba con mi mamá. Lo paja es que ella nunca me decía que hacer, ella me cuestionaba, mucho, pero en buena onda, para que yo pudiese ver las cosas desde distintos ángulos, perspectivas, y hasta el día de hoy ella siempre ha sido la que expresa su amor de distintas maneras, dejando una notita con algo que me preparó, dándome ánimos cuando estoy a full o incluso con un abrazo. Es algo que valoro muchísimo de ella. Ellos como pareja van bien, porque siento que se complementan muchísimo, en donde uno le da al otro lo que no tiene y viceversa. Y han tenido, como cualquier pareja, momentos de crisis, pero han logrado salir adelante. Lo bueno es que cuando han tenido este tipo de problemas, lo han sabido manejar sin gritar o faltarse el respeto, si no cada uno con su espacio, solos, de reconectarse con uno mismo y de ahí volver como pareja, conversándolo previamente. Eso valoro muchísimo de ambos. De hecho es algo que trato de mantener, porque problemas, complicaciones en la pareja se van a dar, el tema es saber manejarlos, conversarlos. Yo observo a mi alrededor, y a veces uno se queda tonto de ver la cantidad de relaciones tóxicas que hay, y que faltándose el respeto, literal mandándose a la $\mathrm{m}$, aún continua, sin respeto, sin asco. Hay relaciones que creo que las personas ya ni saben por qué están juntas... pero igual continúan en esta dinámica, triste pero sucede y mucho. Ósea yo tenía una pareja que era recontra celosa, pero sus celos ya se fueron al límite cuando yo entre a la universidad, y como sabrás el $90 \%$ un salón de psicología son mujeres, y entonces la mayoría de mis amigas eran mujeres pues, ¿qué iba hacer? Pero está loca ya alucinaba cualquier cosa, y eso que las conocía porque yo la incluía en todo los planes post u, desde un plan de cine, hasta ir a una discoteca en barrando, pero ella ya estaba incomoda, incluso sentía que muchas veces propiciaba un ambiente incomodo con su postura, miradas, comentarios por debajo. Lo conversamos, y ella prometió que iba a tratar de lidiar con ello, cambiar, y no pudo, entonces termine con la relación. Cuando alguien no confía en ti, y proyecta sus temas, va a ser algo que nunca va a funcionar hagas lo que hagas. De ahí me di cuenta que no estaba del todo bien, porque ya pasaron como 6, 7 años y a veces me escribe. Medio "creepy", ¿no? Hay personas que no sueltan nunca. Yo a veces le respondo y soy lo más cortante, pero bueno, a veces pasa así. 


\section{E: ¿Y tú, cómo eliges a tu pareja?}

O: Es un proceso que va por etapas... Mientras vas madurando, creciendo, sabes qué quieres, más allá de la atracción o la química, ciertos patrones que dependen de cada persona en base a lo que busca cada persona. Por el lado de la autenticidad, es un patrón que siempre se ha repetido, es algo que me gusta mucho. Físicamente, si identifico a las 4 de las parejas que he tenido son demasiado distintas... Pero siempre han sido chicas bastante abiertas, cero encasilladas en sus ideas, pensamientos, eso me gusta... Poder hablar de muchos temas, sin limitarnos, abiertas a lo que vengan y lo disfrutamos.

\section{E: ¿Qué aspectos conscientes consideras al momento de elegir una pareja?}

O: Que sea auténtica, creo que todas las chicas que me han gustado, sobre todo mi enamorada actual, tienen como su propia personalidad, que se conocen así mismas, pero que saben cómo son y les gusta mostrarse como son, y no mostrarse con máscaras o con fachadas, eso siempre me ha jalado. Que sean personas buenas, que siempre vean el lado bueno de las cosas, el querer ayudar, el tema de ser servicial. El que tenga una mirada a mejorar las cosas, a la sociedad, no sólo pensar en ti, sino en los demás. Que sean mujeres que disfruten de los espacios culturales, también me gusta que sea creativa: abierta a experiencias distintas. Pamela, mi enamorada, es arquitecta, entonces es recontra creativa, pinta increíble. Ha publicado algunos cuadros, modelos que ha diseñado, y algunos de los cuadros que ha vendido a donado el dinero para asociaciones sin fines de lucro, pero que buscan ayudar la salud mental de poblaciones escasas. Eso, eso es admirable de ella, porque no es que le sobre el dinero, pero prioriza a una sociedad que sufre, a una población que demanda, la gente es tocada de mil manera y necesitan este apoyo ¿qué hombre no se enamora de eso?

\section{E: ¿Y qué aspectos inconscientes has identificado con tu terapeuta respecto de tu elección?}

O: Nunca me había puesto a pensar en esto, no llegue a hablarlo con mi terapeuta tampoco, pero algo que podría, que se me ha venido a la cabeza mientras hemos ido conversando... Wow, estoy teniendo un insight... Mira, de hecho mi pareja actual es una persona súper cuidadora, como bien maternal, entonces se me ocurre que esa puede ser de algún modo las razones por las que me atrajo, que me siento bien con ella. Me cuida bastante, en cierto modo, y en ese sentido no lo había tenido antes, una chica que tenga como que este rol de cuidadora, de protegerme, de no hacerme daño... Bueno, de hecho una de mis ex era madre, entonces si lo tenía, pero no lo ejercía tanto conmigo, sino con su bebe. Pero de hecho creo que eso es algo que también admiro, que sean 
mujeres que cuiden, que contengan, que les guste compartir, pero también de manera íntima, no salir un viernes y quedarnos en casa compartiendo, eso también es bonito.

\section{E: ¿Y eso con qué lo asocias?}

O: Ahora que lo pienso, más con mi mamá, con mi papá no tanto... Es que de hecho con mi mamá siempre frente algún conflicto, tuvimos como una cierta complicidad, medio de protección. Yo la cuidaba un montón a ella, y viceversa, de entendernos hablando, de estar preocupados el uno por el otro. Teníamos un espacio y conversábamos de los hechos, de lo que nos molestaba, era un es espacio seguro, y es bacán porque hasta el día de hoy, a pesar de que ya no paso tanto tiempo en casa, ha perdurado esta dinámica de tener nuestro espacio, y para nosotros. Y ella también recurre a mí, y eso es bacán. Y en cierto modo lo tengo ahora con Pamela \{pareja actual $\}$ y eso es bueno. Cuando las cosas son complementarias o se dan de igual a igual en cualquier tipo de relación, incluso de amistad, cuando las cosas van en sintonía, creo que todo fluye. No forzar, no sobre pensar, confiar y que las cosas se den. Hoy en día las personas forjan mucho las relaciones o situaciones, son muy actuadoras, calculadores, ah y demandantes... En cambio cuando dejas de lado el miedo, y confías, las cosas se dan. Aparte creo que uno no elige a alguien para controlarlo o stalkearlo de manera constante...

\section{E: Oscar, ¿Qué es elección de pareja para ti?}

O: Mmm... Es darte cuenta de lo sientes hacia otra persona, de lo que puede haber frente a esta persona, de lo que sientes y lo quieres, y empujarse a conseguirlo. Es como una mutua elección, en donde nunca se escoge, pero es un proceso en el que te das cuenta que quieres estar con alguien, que hay una persona con la que te sientes distinto que el resto de personas: Intentar que pase. 


\section{Participante 4: Adrián}

\section{E: Cuéntame Adrián ¿A qué te dedicas?}

A: Bueno, si bien soy psicólogo clínico ahorita estoy chambeando en recursos humanos, de hecho no pensé quedarme acá, pero me ha gustado poder aplicar todos mis conocimientos clínicos en una empresa. Ellos nos necesitan (entre risas). Es totalmente distinto, pero te abre la mente, el espacio a muchos otros campos, y no me molesta moverme o ir en otras direcciones.

\section{E: ¿Cuándo te graduaste?}

A: Ya hace dos años... hice mi internado en un hospital, fue realmente acercarme al caos que por ahí no estaban tan alejados de mi realidad, pero de hecho ya estar en la cancha es distinto. Lo que al comienzo no me gustaba tanto es que tenía a alguien dentro de la sesión, quien era mi jefa, dependiendo del área en la que estaba, y eso era recontra incómodo. Creo que no sólo para mí, sino para la persona que tenía al frente, imagínate si a veces es difícil contarle algo personal a alguien, y estas tratando de generar vínculo, y no sólo está la persona a la que has recurrido por ayuda, sino dos, ósea recontra observado para todos. Bueno pero de ahí me di cuenta que recién estaba entrando a la cancha y tener la oportunidad de que alguien me diga de manera directa la cagaste en, mejora en o que bien lo hiciste, era un punto a mi favor. Ahora estoy hace casi dos años en una empresa.

\section{E: ¿Y qué rol desempeñas ahí?}

A: Selección de personal, me divierte muchísimo explorar el perfil de cada persona en particular, y verlas desempeñar en un periodo de tiempo sus habilidades y sus limitantes. Pero tengo buen ojo cuando de elegir se trata (risas).

\section{E: Cuéntame un poco de ti, sobre tu infancia.}

A: Mi infancia... es fuerte, de hecho me la pase cuidando mucho a mi mamá. Pasa que mi papá es alcohólico, siempre lo ha sido. Su vida ha sido de estar en casa por periodos, y de ahí recaídas, y por ello volvía a su centro. No podíamos dejarlo sólo, no podíamos dejar ningún tipo de botella, era como un peligro y un niño al mismo tiempo para nosotros. Mi mamá ha sufrido muchísimo, ella ha sido como padre y madre finalmente para mí, ella era la que la luchaba, trabajaba, siempre. Imagínate, 20 años de cuidar a mi papá... Y mi infancia no sólo estuvo afectada por mi papá, sino que pucha en mi colegio también estaba lleno de bullys, y yo el típico retraído, que tocaba el piano y me llamaban para las obras de teatro, y que era el "rarito", porque yo siempre supe que era gay, ya te imaginarás, todo el perfil de niño para joder. Entonces he sentido una carga 
constante en mí, y no era para menos, siendo tan pequeño y sentir que mi papá se podía morir en cualquier momento, mi mamá sin tener mucha paz interna, y no sólo trabajar a full, sino cuidar de mi hermana menor y a mí. Mica es mi hermana, tiene 22 y ella es genial. Es como una niña grande, es súper madura, me encanta lo independiente que es y cómo se va formando como mujer, aunque para mí siempre va a ser una niña, mi niña. Con ella siempre tuve cierta complicidad, de hecho ella fue la primera en saber que era gay, antes que mi mamá, aunque yo sabía que mi mamá ya sabía... pero con ella lo compartí primero porque siempre estuvimos juntos, y el hecho de compartir momentos difíciles, momentos buenos, hizo que maduremos juntos y que nuestra relación siempre fuese de cuidado, comprensión, y estar preocupado el uno del otro, más que mi mamá también tenía otro niño que cuidar. Creo que siempre hemos sido un buen equipo, difícil por lo que vivíamos día a día, pero hemos podido salir adelante.

\section{E: ¿Y cómo está ahora tu papá?}

A: Internado... creo que el ya no tiene solución, sé que las adicciones son las enfermedades más mierda, porque te consumen, y nunca es suficiente. Aprender a vivir con eso es peor, a menos que la sublimes o traslades a otra cosa, pero con él no se puede. Aparte sólo nos tiene a nosotros tres, sus hermanos están totalmente desentendidos, no contamos con ningún apoyo de parte de ellos, ni de apoyo, menos económico, porque estos centros cuestan la vida, entonces es realmente dolor de cabeza. La relación que lleva con mi mamá ya es de amistad, de apoyo, pero en realidad mi mamá es una mujer excepcional, yo siempre digo que mi mamá para mi papá ha sido como un ángel de la guarda, porque si ella no hubiese existido en su vida, o si hubiera tirado la toalla mucho antes, ¿qué sería de él? Nadie se hubiese hecho cargo jamás. Por eso también la admiro, porque es una persona que cuida del otro, que se preocupa de ti.

\section{$\mathrm{E}:$ ¿Y tú, cómo eliges a tu pareja?}

A: Creo que he dejado que las cosas sucedan, hasta donde han debido de llegar. Por el lado de los salientes, he tenido muchos salientes, unos peor que otros (entre risas), unos que te vendían como si quisieran algo serio, pero sólo querían sexo, ósea está bien que quieras sexo, pero no vendas algo que no buscas, eso molesta... Bueno también la sociedad limeña que está más enjaulada, o los que viven una doble vida. A veces me llegaban "inbox" de gente que yo decía oye pero este tiene flaca, ¿o este no se vende como hetero? Otros estaban en proceso de saber quiénes eran, de curiosear, de todo te encuentras ahora en las aplicaciones (risas), y sobre todo que es bien cerrado en general este mundo, tabú aún, la gente se asusta de aceptarse, más aún de mostrarse. Pero bueno 
parejas serias sólo dos, o bueno en realidad mi actual, porque el anterior creo que nunca asumió lo que éramos, pero para mí sí éramos una pareja.Alguien que se quiera, que se respete, que sea fuerte en el sentido de que no se "bajonee" o se deje pisotear por nada ni nadie. Alguien con actitud, buena onda, que busque también pasar tiempo con mi familia, porque para mí eso es importante y lo bueno es que Jorge, mi pareja actual, disfruta pasar tiempo con ellos. Ahora que lo pienso con él también fue así, hasta que decidimos oficializar, pero ahora chocamos un poco en cuanto a valores, porque yo soy de la idea de que si te provoca tener relaciones sexuales con alguien, anda y hazlo, total eso no va a cambiar que dejes de querer a esa persona con la que estas. Para mi pareja no, tiene que haber exclusividad y eso no me está gustando.

\section{E: ¿Como "fue así”?}

A: Ósea que nos conocimos por aplicación, fluíamos, pasaban cosas, como por 3, 4 meses, pero nadie nunca habló de relación hasta que nos dimos cuenta que actuábamos como si estuviéramos en una y nos oficializamos. Ósea él iba a mi casa, yo a la suya, nuestras familias sabían de nuestra opción y así no más o porque sí no llevas a un hombre gay a tu casa, eso ya hablaba de un compromiso. $\mathrm{Y}$ algo así me paso con un pata, que no sé por qué se me quedo muchísimo. Sólo salimos una vez, sólo paso una vez, pero me quede pegado a él, a veces hay gente con la que haces química rápido, pero este pata era difícil de leer, pero me atraía muchísimo, y nunca apareció, o una vez me volvió a escribir, pero de volver a vernos no.

\section{E: ¿Qué aspectos conscientes consideras al momento de elegir una pareja?}

A: Cuando su personalidad me jala, me mueve, yo siento que hay como algo, porque mi enamorado actual físicamente no es la persona en la que me hubiese fijado desde un principio. Entonces en la conversación que tuvimos, me gustó. Si bien yo puedo ser muy visual a veces, la personalidad al final es lo que tiene más peso. Y que sea una persona con la cual pueda hacer tiempo, porque hay gente con la que te aburres o no fluye, pero creo que eso también está dentro de la personalidad de una persona. Finalmente el físico se va, ósea con el tiempo, y lo que queda de alguien es lo que tiene.

\section{E: ¿Qué aspectos inconscientes has identificado con tu terapeuta respecto de tus elecciones?}

A: Yo en un periodo estaba reaccionando súper mal con mi pareja, era como si lo estuviese probando y mostrando mi peor lado. Mis reacciones como bajarme del carro abruptamente o gritarlo de manera agresiva, y consecutiva nos estaba afectando. Entonces lo hable con mi terapeuta, y me dijo tal cual eran las cosas: Adrián, tú le estas 
mostrando tu peor parte, lo estas botando porque necesitas saber que él se va a quedar a pesar de cualquier cosa, y que no se va a ir como tu papá se fue. Ósea es como así yo sea una cagada, igual va estar conmigo, me va a aceptar. Con él me fui dando cuenta de que él es una persona que busca hacerse cargo de otros, y que yo soy una persona que busca que se hagan cargo de él, ósea de mí. Y en el caso de otras personas, creo que lo que más me ha motivado es demostrarles que puedo, que puedo conseguir algo por mis propios medios y ellos lo vean.

\section{E: ¿Y qué patrones crees que se han repetido en tus distintas elecciones?}

A: Mmm, pucha como yo muchas veces me he sentido incapaz de conseguir algo, muchas veces aceptaba lo que venía. A veces eso me ha fastidiado, porque de todas las personas con las que me he involucrado: ¿Cuántas personas han sido realmente las que me han gustado? Yo aceptaba lo que venía, bueno yo lo permitía. Pero el problema es que nunca los he conocido muy bien, pero de hecho me han llamado más la atención las personas de carácter fuerte, que tienen las cosas claras, que son seguras, eso.

\section{E: Mencionaste que tuviste un periodo en donde estabas reaccionando mal con tu} pareja, como si lo estuvieses de alguna manera retando, mostrando tu peor lado, ¿cómo asocias esto en cuanto a tus vínculos primarios?

A: Con mi pareja, como te comente es un poco como una mamá, que le gusta hacerse cargo de todo y de todos. Y mi mamá es un poco así, no por gusto se hizo cargo de mi papá que sufría de alcoholismo por tantos años. ¡Mi mamá estuvo más de 20 años así! Respecto a mi papá, mi pareja también de repente me ha ayudado a sacar ese lado más juguetón que tengo, que antes por ahí lo tenía, pero nunca lo había mostrado, y mi papá es como un niño. Y en el caso del chico con el que fue mi primera relación sexual y sólo lo vi una vez, de hecho me ha marcado más que otras cosas... a veces lo pienso. Creo que su actitud, súper creído, no sé mi papá también es así. Y físicamente tienen onda, son agraciados los dos. No sé si me impacto tanto él, porque no sentí de él, la aceptación que buscaba tener, y tampoco la he sentido por parte de mi papá. Porque mi papá siempre, volcó muchas de sus propias frustraciones en mí.

\section{E: ¿Cómo así?}

A: No sé, ósea no estuvo muy presente, no sé si porque como no podía con el mismo, que iba a poder con sus hijos, pero nunca estuvo, o estuvo pero nulo. Actuaciones de colegio, graduaciones, momentos importantes... Nunca. Nunca se ha preocupado por como la he pasado yo o cómo me siento yo, él sabe que soy gay y nunca me ha hablado de eso, como cree que me siento. Sé que es un niño, yo me siento más adulto o 
responsable que él, o que yo debo cuidar de él, pero al final ¿quién cuida de mí? Ósea a final el miedo, el cuidado, el no salir mucho tiempo de casa por él, era como dejar a un bebé solo. Y al final es como que sabemos que está sólo, que sólo nos tiene a nosotros, entonces es como que no queda de otra, pero también es nuestro papá. No sé qué tanto quiera el salvarse, porque igual así quieras ser salvado, te van a salvar, pero al final el convencido de querer ser salvado eres tú, no los demás, eso es momentáneo. Yo espero siempre que el encuentre paz, así sea poca o por periodos cortos, que pueda estar bien. No le deseo la vida que él ha llevado a nadie. El tema de las adicciones no sólo consume al familiar que las padece, sino a toda su familia nuclear, porque uno siente como si fuera el paciente, sentir la impulsividad, ansiedad de golpear algo o a alguien si es que no le das lo que esa persona según el "necesita", como un trago de whiskey, chicotea, y chicotea mal. Es horrible ver a mi papá en estas crisis. Entonces miedo a que golpee todas las puertas de los cuartos, o se fugue para conseguir licor, era algo bien fuerte. Pero bueno, es lo que me tocó a mí vivir, a mi mamá y a mi hermana.

\section{E: Para terminar Adrián, ¿qué es elección de pareja para ti?}

A: Es lo que eliges. Porque yo no en el amor así nomás no creo, simplemente creo que hay enganches, un poco en base a cómo eres tú, cómo ha sido tu experiencia en base a quienes son tus padres. Y tú solamente a veces encuentras un gancho con alguien. Ese gancho vendría a ser el vínculo, en el cual pegas con alguien. Ese gancho, claro a veces es sano y a vece no. Entonces yo creo que es un poco eso, por eso es que uno se enamora, porque encuentra esas cosas. Pienso que es un tema básicamente súper psicológico, y químico. 


\section{Participante 5: Sofía}

E: Sofía, cuéntame: ¿Cuántos años tienes?

S: Tengo 24 años

E: ¿Cuándo te recibiste?

S: Mmm, termine la carrera y el internado en diciembre del 2014 en la católica, me gradué en el 2015, y me licencie en diciembre del 2015.

\section{$\mathrm{E}:$ ¿Te interesa la psicoterapia?}

S: Sí claro, pero más que nada me enfoco en niños y adolescentes.

\section{E: Actualmente, ¿trabajas?}

S: Sí, trabajo en dos lugares: en un nido como psicóloga, y en una compañía de teatro, circo y música también como psicóloga, y además hago acompañamiento terapéutico.

\section{E: ¿Cómo te va en eso?}

S: Bien, de hecho empezar a trabajar es difícil, porque sales del internado que es un contrato hasta cierto tiempo, y si todavía no eres licenciada, si todavía no eres colegiada, hay muchos baches. Entonces, el año pasado que recién acababa de egresar y todavía no me licenciaba, trabaje en la casa amarilla y bravazo porque tiene una metodología bien interesante a partir del vínculo con los niños. De hecho aprendí un montón, además que el trabajo era a medio tiempo, entonces tenía tiempo en las tardes para enfocarme en lo que era mi tesis y terminarla. Entonces me licencie, y ahora licenciada ya no mas casa amarilla, le dije a la directora: "lo siento, quiero enfocarme en mi carrera". Ya como en Febrero, inicios de Marzo, buscando trabajo en donde sea, hasta que me salió. Por eso ahora ya mucho más tranquila, de hecho en el nido trabajo sola, entonces es distinto, porque tengo mucho que aportar en base a mi experiencia y conocimientos, eso me gusta.

\section{E: ¿Y en la compañía artística qué rol desempeñas?}

$\mathrm{S}$ : Ahí soy psicóloga, ellos tienen un programa de escuela y talleres para niños y adolescentes, y además tienen otro programa que se llama "Cuerda Firme", que es para chicos de 19 a 29 años, que vienen de estatus socioeconómicos muy bajos, entonces lo que yo hago es acompañar a los que aprenden teatro, circo, música, tanto en los niños como en los adultos, los acompaño porque de hecho movilizan un montón de cosas. Y también damos un espacio para hablar con los padres, en el caso de los niños, y de los jóvenes para hablar con ellos mimo. También sé que me va a corresponder ver temas de selección a los jóvenes del elenco del circo, también de la gente que va a trabajar en la 
carpa, pero eso va a ser más adelante, ya que por ahora me centro más que nada en acompañar en estos talleres, para chicos, y para adultos.

\author{
E: Qué interesante, ¿cuánto tiempo tienes trabajando allí? \\ S: 1 mes \\ E: ¿Y en el nido? \\ S: 2 meses
}

\title{
E: Cuéntame Sofía, ¿tienes hermanos?
}

S: Sí, tengo tres hermanas mujeres. Las dos mayores son hijas de mi papá, y la menor es hija de mi papá y mi mamá, yo soy la tercera.

E: Las dos mayores son hijas de tu papá, y la menor biológica de ambos padres, y tú eres la mayor de ambos. ¿Vives con ellos?

$\mathrm{S}$ : Vivo con mis papas, y mi hermana menor. Mis hermanas mayores ya se casaron.

\section{E: ¿Y a qué se dedica tu mamá?}

S: Mi mamá es economista, es jefa de tesorería de presupuestos en una empresa y tiene 57 años. Mi papá tiene 5 años más y es economista también. Actualmente se dedica a la docencia.

\section{E: Cuéntame un poco sobre tus hermanas.}

S: La mayor, se llama Milagros, tendrá 38, Verónica tiene 34, yo 24, y Adriana tiene 22.

E: ¿A qué se dedica Adriana?

S: Está estudiando marketing.

\section{E: ¿Por qué psicología?}

S: Este... La verdad que siempre he querido estudiar psicología. Nunca lo dude desde los 13, 14 años. Mi papá y mi mamá siempre han estado metidos en la iglesia y sus cosas. Entonces, mi mamá siguió un curso de familia, y en estos cursos recibió también cursos de psicología, y por ahí que encontré sus cosas y me puse a leer. Me puse a leer todas sus separatas, y antes que mi mamá las termine yo ya las había leído todas. De hecho en el colegio, a diferencia de casi todas las de mi promoción, a mí me encantaba leer. Yo leía un montón, un montón, un montón. Entonces me encantó el tema, y seguí leyendo y leyendo, y llegué a quinto de secundaria descubriendo el curso de psicología y de hecho ya me sabía todo. No de manera soberbia, sino que me interesaba mucho, y ya el curso se me hacía fácil, y dije psicología, ya que siempre me había llamado mucho la atención, y no es que para mí haya sido difícil cuando llegue a la universidad optar por una carrera. Igual en la universidad llevo dos años de generales en letras, entonces escogí la universidad católica, ya que dije si hay algo que no he descubierto aún, ahí 
tengo la oportunidad de verlo. De hecho en números soy un cero a la izquierda, entonces números no era una opción para mí, definitivamente letras. Me metí a la carrera, pero en definitiva en letras el curso de psicología no me gusto, pero los otros tampoco me encantaron. Una vez ya en la facultad sí me gustó mucho más.

\section{E: Claro, es entendible. Y cuéntame, ¿cómo te llevas con tu hermana?}

S: ¿Con cuál hermana?

\section{E: Con Adriana}

S: Bien, de hecho ella es muy diferente a mí. Ella se ha posicionado como la, y lo dice abiertamente, que ella detesta la psicología, que ella odia a los niños, y ella va más con lo que ella hace ¿no? De marketing, de las empresas, de la moda, entonces sí somos bien diferentes...

\section{E: ¿Chocan?}

S: Sí, a veces chocamos, pero es mi hermana, de hecho la quiero un montón. Cuando pasa algo importante estoy pendiente de ella, y ella también está pendiente de mí, nos preocupamos. Justo ahorita está pasando por una entrevista entonces estoy pendiente "ay como le abra ido", por más que seamos tan distintas. Yo, por lo mismo de la carrera, soy una persona sensible, me preocupo por las emociones de los demás. Adriana es abiertamente fría, parca, con sus amigos sí todo bien, pero incluso sus amigos la definen como la de "Los locos Adams", Merlina, así es, ella es Adriana. Entonces, de hecho para mí que soy más sensible y emocional, me cuesta muchas veces llegar a ella, y a ella le cuesta llegar a mí, pero hemos aprendido con los años a convivir y yo sé que hay ciertas cosas como, ya sé cómo tratarla, y ella sabe cómo tratarme a mí. Se ha logrado con trabajo y esfuerzo la relación.

\section{E: Qué bueno, y ¿cómo te llevas con tu mamá?}

S: Bien, mi mamá es como yo igualita.

E: Es decir, emocional, sensible...

S: Claro, emocional, sensible, de hecho también chocamos ¿no? A veces yo digo algo y veo que a ella le afecta emocionalmente, entonces tan bien la conozco, ya los 24 años no son por gusto... Voy, le pregunto cómo está. Hay veces en las que sé cuándo preguntarle, y cuándo no preguntarle, porque ya veo las reacciones que está teniendo, pero ante cualquier situación lo conversamos, ya es diferente ¿no? A cuando era más niña, el trato y la cercanía es distinta. 


\section{E: ¿Y con tu papá?}

S: Es el engreído de la casa, como ya te imaginarás es el único hombre, entonces mi papá es así. Es sensible, también tiene su carácter, pero yo creo que a diferencia de cuando era niña, a lo que soy ahora, mi papá ha dado un giro de 360 grados o 180 mejor dicho. Porque en definitiva antes se encargaba de mis hermanas, de nosotras, y era mucho más estricto. Ahora que somos grandes ha cambiado de papel y quiere que todo el mundo lo engría.

\section{E: ¿Cómo estricto?}

S: Estricto en el sentido de las notas, de la hora de llegada, sobre todo con mis hermanos mayores, porque prácticamente mi papá las crio solo.

\section{E: ¿Vivían todos juntos?}

S: Sí, vivíamos todos juntos.

\section{E: Y la mamá de ellas...}

S: Falleció cuando eran muy chicas, entonces claro yo tenía la visión de mi papá de cómo fue con mis hermanas, y yo de chiquita lo veía. Ahora no, mi papá llega y está diciendo: "nadie me ha preguntado cómo estoy", "nadie me ha preguntado cómo me ha ido", así... pero lindo también.

\section{E: ¿Y con tus hermanas mayores?}

$\mathrm{S}$ : Bien también, de hecho no las veo tanto como me gustaría. Se casaron, pero igual desde antes de casarse se mudaron solas. Primero juntas, y después por separado cuando Verónica se casó. De hecho no las veo tanto, pero cuando las veo siempre es en sus cumpleaños, día del padre...

\section{E: Eres más cercana a Adriana}

S: Claro, soy mucho más cercana a Adriana, porque vivo con ella también. Pero por ejemplo, Verónica ahorita ha abierto su negocio propio, y la estamos ayudando a full, está construyendo su peluquería. Con Milagros también, de hecho ella tiene un carácter más especial, igual nos juntamos, incluso a veces vamos a tomar lonche las cuatro. El año pasado se casó, estábamos súper metidas en el evento del matrimonio. Quería que la ayudemos a elegir hasta el esmalte de uñas que iba a usar, para todo nos pedía ayuda... De hecho nos juntó un montón.

\section{E: ¿Y tienen hijos?}

S: No, no tienen hijos lamentablemente (entre risas). En un futuro sí, espero.

\section{E: Y cuéntame Sofía, ¿tienes pareja?}

S: Sí, desde hace un año diez meses. 


\section{E: ¿Y has tenido otras parejas?}

S: Bueno, la del colegio no la cuento mucho, pero podría contarla... Y otra que no la cuento (se pone a contar). Bueno, dos y medio.

\section{E: ¿Dos y medio?}

S: Claro, la de colegio, la que duró dos años, y después también con otro, pero nunca formalizamos... Era más liberal la situación. Y ahora con Álvaro que sí es algo estable.

\section{E: ¿Y por qué no cuentas la del colegio?}

S: Sí, debería contarlo, pero era algo mucho más infantil.

\section{E: ¿Qué edad tenías ahí?}

S: 14

\section{E: Mmm, no tan infantil.}

S: No, no tan infantil yo sé, pero igual como no lo veía, era más como de adorno.

\section{E: ¿Cuánto tiempo estuviste con él?}

S: Estuve un año, ¿sabes? Pero como te digo, casi no nos veíamos. Al saliente, Mario, sí lo cuento porque si me preguntas hay mucho por contar y sucedió antes de estar con Álvaro, quien es mi actual enamorado. Entonces yo deje en un inicio de darle la oportunidad a Álvaro, por Mario. Entonces, si Mario no me hubiese interesado para nada, no hubiese sucedido ello.

\section{E: Entones, ¿en realidad sí quisiste estar con Mario?}

S: No, no, no. Bueno sí, probablemente sí, pero él se fue a vivir a otro país.

\section{E: Entonces como que no se concretó.}

S: No se concretó porque él se fue a otro país, pero después empecé a conocer un poco más a Álvaro y me di cuenta que en verdad Mario no me interesaba tanto. Después llegó un momento en que converse con Mario, y de hecho él me dijo lo mismo, y acordamos que hasta aquí no más, y que cuando regresará íbamos a ver en qué andamos, pero ese "hasta aquí nomás", me dio puerta libre para hablar con Álvaro, y empezamos a salir y ya hasta la actualidad que somos una pareja. Después de un tiempo llego Mario y...

\section{E: Mario regreso, ¿qué ocurrió?}

S: Claro, regreso. Álvaro y él se conocen. No se quieren mucho, pero se conocen. Todo bien, somos amigos.

\section{E: Bueno Sofía, cuéntame ¿Cómo eliges a tu pareja?}

S: ¿Cómo elijo a mi pareja, en general? Mmm... Me importa mucho primero la conexión: La conexión que pueda tener con esa persona, lo que otros pueden llamar química. El hecho de que me pueda llevar bien con esa persona, que me sienta tranquila 
y segura, siendo yo misma, y que esta persona se sienta igual conmigo. Me importa mucho que la persona sea una persona que le importe su vida, en el sentido que si le gusta el arte, que se dedique al arte. No es que ande "pinponeando" por la vida sin darle un sentido. Por lo mismo que yo le doy mucha importancia a mi vida, busco que la persona que me acompañe también tenga metas en la vida, y que apunte a ellas. No que su meta sea por ejemplo "llegar a la luna", y que lo que estudie o haga no esté relacionado o apuntado a ello. ¿Por qué? Porque me importa eso, ¿no? Que sean personas que busquen, y den todo lo posible para conseguir sus objetivos. Eso a mí me importa mucho. Aparte de esto que te cuento, que haya conexión, que tenga carisma, que el tiempo que pase con esa persona sea bonito, y eso.

\section{E: Y, ¿qué aspectos inconscientes has identificado con tu terapeuta en tu elección?}

S: De hecho, bueno es lo que yo he estudiado también, el apego. Me parece increíble ver cómo los vínculos primarios, en el sentido del holding, la búsqueda de confianza y seguridad, la puedas encontrar en tu pareja, me parece como básico, ¿no? También esto de la base segura, ser capaz de estar tranquilo con tu pareja, feliz, pero también ser capaz de explorar, de hacer tu vida tranquilo y luego regresar, bueno no regresar, saber que tu pareja va a estar ahí apoyándote, y que no te va a fallar. Son cosas bien primarias, que se consiguen en tus vínculos primarios, que son básicas para una pareja, para una relación de pareja.

\section{E: ¿Y por qué consideras que es tan importante para ti esto?}

$\mathrm{S}$ : Me parece importante justo esto último, porque soy una persona bastante independiente. En el sentido de que me gusta mucho tener tiempo para mí, tener tiempo para mis amigas, tener tiempo para hacer mis cosas. De hecho la carrera que he escogido, las cosas que me gustan hacer son más que nada sola, me gusta pintar, pero me gustan mis tiempos a solas, como leer. Valoro tanto estos tiempos a solas, que no haya alguien que sea intrusivo, ya que estos tiempos para mí son preciados, los cuales yo necesito que mi pareja los acepte: soy una persona independiente, a mí me gusta pagar mis cosas, me gusta conseguir ganar mi plata, no sé, ganar mis propias cosas yo las valoro mucho. Entonces muchas veces, de hecho he salido con varias personas, y cuando las veía muy intrusivas yo me alejaba totalmente, porque no aguantaba, decía “pucha no, me está hablando demasiado, no soporto”, sentía que me invadía. Entonces yo necesito un equilibrio, porque también me encanta estar con mi enamorado y chorrear, estar juntos, irnos de viaje, escaparnos, es algo que valoro un montón y siempre estamos programando hacer cosas juntos, y lo veo seguido, pero durante el día 
él está en el trabajo, haciendo sus cosas, haciendo su tesis también, juntándose con sus amigos, y yo también estoy haciendo mis trabajos, con mis amigas. Es más desde el principio lo consideramos importante, como por ejemplo me dice: "Amor, ¿te voy a visitar?” Y yo le digo: "No, estoy en sofitime”, y él también me lo dice, todo bien. O si no también utiliza el "estoy haciendo mis cosas", aunque siempre es un misterio qué cosas hace. Hasta ahora no sé, aunque después de esa frase me dice que vendrá a mi casa, y todo bien. A veces estamos en una reunión, no sé en mi casa, y mis amigas me preguntan: ¿Y Álvaro, no va a venir? Y yo: “Ah, está haciendo sus cosas y de ahí viene”, y mis amigas me preguntan: “¿Pero qué son sus cosas?” Y se alarman - entre risas-.

\section{E: Y no te interesa saber, ¿qué son "sus cosas"?}

S: Bueno, sí sé qué hace, está respondiendo algunos correos, su tesis, sus cosas ¿no? Pero sí confío un montón en él. Eso también me parece básico.

E: Mencionaste un montón lo del vínculo ¿no? Del holding, el sentirse segura: ¿qué relación encuentras entre esto que mencionas con tu infancia?

S: Con mi infancia...

\section{E: Siempre tuviste un ambiente, por decirlo ¿contenedor, desde pequeña?}

S: Sí, de hecho sí. Claro para mí es súper importante, por lo mismo de mis historia. Yo llegué en una familia que un poco como que recién se formaba, mi papá con sus dos hijas que ya tenían más de diez años, mi mamá, y ya yo llegue de hecho de sorpresa, ¿no? Pero yo llegué y era como la bebé de la casa. Todas las atenciones, y bueno posteriormente llegó Adriana, pero igual las dos éramos, somos bastante seguidas. Entonces, yo recuerdo mi infancia como bien pegada a mi familia.

\section{E: ¿Eran muy sobreprotectores tus papás?}

S: Sí, hasta ahora (entre risas).

\section{$\mathrm{E}:$ ¿Y cómo manejas ello con el tema de tu independencia?}

S: Sí, me cuesta. De hecho ya no tanto, pero cuando tuve la oportunidad me empecé a desligar. Mi papá por ejemplo trabajaba en una empresa bastantes horas al día, y a la par la docencia, pero hubo un momento que no aguantó, y renunció a la empresa. Todos nos quedamos con la idea: “y ahora, ¿qué va hacer?”. Estábamos dos en la universidad, bueno Adriana comenzaba la universidad, y bueno mis hermanas ya no estaban, pero igual nos quedamos así. Y yo dije: "Bueno, empiezo a trabajar". Me metí a una consultora, recuerdo que lo deteste, pero me metí a trabajar. Yo empiezo a ganar mi plata, quería comenzar a pagarme ciertas cosas. Dejé la consultora a los tres meses, no 
aguante, no era lo mío estar sentada en una oficina, no me gusta. Pero igual me busqué cualquier cosa, ya que empecé a dar clases a niños, todo lo que se me acercaba lo tomaba. Entonces, hasta ahora, no dependo tanto de que mis papas me estén comprando cosas, o por ejemplo ya no pido permiso para viajar, ósea les cuento, lo mismo con los fines de semana, porque siento que yo soy dueña de mi dinero, de lo que yo gano, de lo que yo administro, entonces ahí aproveche para distanciarme.

\section{E: Está bien, y cuéntame ¿cómo es Álvaro?}

$\mathrm{S}$ : Es bien bueno, es un chico sensible, es un chico que tiene como los principios bien puestos, es bien moralista, entonces defiende a morir lo que quiere, lo que piensa, a veces chocamos, porque yo también soy bien necia con lo que pienso.

\section{E: ¿En qué chocan?}

S: Él es economista, para empezar, entonces él es full números, las ciencias son exactas, y yo le vengo con mis rollos de "me preocupa la sociedad", "me preocupa esto y el otro", no sé en temas de política chocábamos. Pero por ejemplo, hace un tiempo le dije que la inteligencia venía por parte de la madre, “¿para qué le dije eso?”. Se murió diciéndome que no, que eso era una investigación, que no está científicamente comprobado. Yo empecé, pero yo he estudiado eso, de hecho si hay bastantes publicaciones que lo afirman, hay estudios. Termino en una discusión.

\section{E: Posiblemente hayas atacado contra términos de ego ¿no?}

S: Sí, sí exacto. Pero después Álvaro es una persona que se toma su tiempo, en qué sentido se toma su tiempo, es como bien meticuloso, perfeccionista, entonces cuando hace su trabajo lo valoran un montón, porque hace su chamba que es analizar, se mete a profundidad y se involucra un montón, y lo hace súper bien. Pero en ese transcurso se demora bastante, porque le dedica un montón de tiempo. Lo mismo sucede cuando tiene que alistarse, demora horas. Yo ya estoy lista, esperando, mientras que él está ordenando su ropa, se afeita perfecto la barba, es bien meticuloso en sus cosas. Es súper amable, jamás lo vas a ver molesto, a todo el mundo le cae súper bien, porque siempre está sonriendo y siempre es súper positivo. Hay veces en que yo veo algunas cosas y digo "pucha ya fue", lo llevo al lado negativo, y él lo soluciona rápido. El ve las cosas desde el vaso medio lleno, entonces siempre está ahí para apoyarme, para motivarme. Y lo que me gusta de la relación que tengo ahorita es que siempre nos vemos juntos, ósea cualquier meta que yo me proponga, por más que sea independiente él se une a mi equipo, no de manera invasiva y dice: “ya, lo vamos a lograr”, y funciona. Igual él ahora está haciendo su tesis, y también me he sumado. No es que voy y lo ayudo con su tesis, 
pero sí nos organizamos para que él tenga tiempo para su tesis, le pregunto cómo va, en qué está, porque cuando hay algo que no lo motiva hay que estar ahí detrás.

\section{E: Y cuéntame, ¿cómo es la relación de tus papás?}

S: Es buena, sí. Mis papas como te dije son bien religiosos, entonces desde que yo estaba en el colegio, como en sexto grado, mis papas se metieron, porque los invitaron, como a un movimiento, que se trataba de un retiro de parejas. Y con eso, hasta el día de hoy mis papas son como servidores, ya que ellos ayudan a parejas que tienen ciertas dificultades en su matrimonio. ¡Y van al retiro, feliz! Por ejemplo, a veces voy a Wong con mi mamá, y se encuentra con todo el Perú. Mi papá no tanto porque los fines de semana está viajando a sus cursos últimamente, pero igual la acompaña cada vez que puede.

\section{E: ¿Pero ellos como relación?}

S: Bueno a partir de ese momento, cuando yo estaba en sexto grado, de hecho su relación cambió, porque tienen momentos para ellos solos, los veo que conversan un montón en las noches, mi mamá engríe un montón a mi papá, mi papá siempre que está de viaje escucho que le manda mensajes de voz preguntándole “¿cómo está mi amorcito?” y esas cosas. Mi papá dice que mi mamá es su ángel, como que ama a mi mamá, no es que sean muy demostrativos, en el sentido que no los ves uno encima del otro, pero sí hay mucho respeto, admiración. ¡Ahí está! Estoy teniendo un insight, eso es lo que hay en ellos, admiración. Eso es lo que yo busco en mi pareja, que yo pueda admirarla, exactamente.

\section{E: Mmm, ¿y sientes que hay alguna conexión entre tu papá y Álvaro? Fuera de que ambos estudian economía.}

S: Este - entre risas-... Sí y no. No porque mi papá tiene ciertas características que Álvaro no las tiene, como por ejemplo, bueno los dos sí son meticulosos en su trabajo, son sensibles, son emocionales, los dos buscan lo mejor para quienes los rodean, pero mientras mi papá cuando tiene un trabajo se lo cuenta a todo el Perú y se angustia, y quiere que todos estemos detrás de él, mientras que Álvaro cuando tiene un problema hay que sacárselo con cucharita. Bueno yo ya aprendí cómo hacerlo, entonces estoy ahí diciéndole "algo te pasa", "cuéntame", pero no es que sus afectos puedan interferir en lo que él está haciendo porque de hecho los maneja, y los maneja bien. Salvo cuando está conmigo y lo demuestra un poco más, ya que somos un equipo y deja ver sus emociones. 


\section{E: Un equipo como el de papá y mamá, ¿no?}

S: Sí, claro. En cambio mi papá es como "me duele la espalda, me duele la espalda", todo el mundo se entera de que le duele, de que no puede caminar, y de que no va a poder viajar porque le duele la espalda. Entonces está así, y mis hermanas vienen a engreírlo porque le duele la espalda. Hoy día en el desayuno por ejemplo mi papá dijo: “ya salieron mis resultados, por favor tráiganlos", para esto obviamente mi papá ya los leyó 30 veces, y ya investigó en Internet qué significa lumbalgia. Pero mientras nosotras estamos ayudándolo en el sentido de que no se deprima, sigue haciendo tu vida, él menciona todas estas cosas. Por ejemplo, en el verano, él estaba llevando un curso, lo estaba dictando, pero él había hecho unas acomodaciones porque nos fuimos de viaje a Brasil los cuatro, solamente falto a una clase, y al regresar a Lima, al parecer su curso lo había tomado otro profesor, se lo quitaron, entonces a mi papá en verdad le afecto un montón. Él ya había preparado todo su curso, era un ingreso que él ya tenía considerado, él ya había avisado, entonces que le suceda esto sí le afecto bastante. Y también lo demostró, no lo hizo público, pero si siento que le impide avanzar, porque si bien ya pas + o este problema, un poco que le sigue dando vueltas al asunto...

\section{$\mathrm{E}: \mathrm{Y}$ a ti te gusta lo contrario, que avance}

S: Exactamente, me gusta que avance. También claro, porque yo he vivido con mi papá toda mi vida, y he visto como muchas cosas que le pasan y le da vueltas, y más vueltas. Y sí, eso me fastidia, me incomoda.

\section{E: Claro, te incomoda que se estanque, por así decirlo.}

S: Que se estanque, claro

E: Encuentras algo en común en tus tres relaciones, o cuatro, como tu prefieras ubicarlos.

S: (Ríe). Algo común entre los tres... ¡Qué difícil pregunta!

\section{E: Puedes pensar qué te gusto de uno, que te gustó de otro.}

S: Ya, a ver, vamos a pensar un ratito. En el caso de Rodrigo fue extraño, porque él era mi mejor amigo, entonces de hecho lo que yo valoraba en él, era esta confianza y cercanía que teníamos.

\section{E: Holding nuevamente}

S: Sí, es más, fue mi enamorado de un día para el otro. Después Mario, no era mi amigo, pero sí era de estas personas que luchaban y luchaban por lo que querían, entonces le di la oportunidad. Y después, Álvaro era el más necio de los tres...\} 


\section{E: ¿EI más determinado?}

S: Sí, el más determinado. Rodrigo no tanto, ah. Pero tenía el otro plus que era mi amigo de tiempo.

\section{E: Tengo una curiosidad, ¿Qué te llevo ir a terapia?}

S: Estoy, y fui porque entre justo antes de entrar al internado, cuando estaba en capacitación y yo trabaje con niños que tenían autismo, y temas neurológicos, poblaciones muy paupérrimas. Entonces, yo sentía que habían muchas cosas de mí que necesitaba manejar, por el hecho de que soy bastante emocional, antes de entrar al internado. Entonces, yo fui con eso. Claro que en el momento le comente que quería conocerme un poco, yo sentía que en ese momento era más inmadura, en el sentido de que en ese momento las emociones me ganaban muchísimo. Y, si me ponía triste o cualquier emoción negativa o la negaba o la reprimía... Más me iba al acting, y no las procesaba. Entonces sentía que necesitaba este espacio para procesar eso, y también para trabajar temas de familia. Justo lo que te comenté al principio, de la relación con mi hermana menor. Ha sido duro trabajar este tema de diferenciarnos, y ahora llevarnos bien, como también este proceso de terapia ha sido para eso, ¿no? Porque de hecho es una persona con la que convivo, por lo mismo que somos muy diferentes chocamos mucho.

\section{E: ¿Con Álvaro no chocas?}

S: No, sólo cuando hay estas cosas donde ambos somos necios, pero por ejemplo hemos quedado que no vamos a hablar de temas de política y ya, se soluciona todo. Es que es “Castañedista”, “cómo le va a gustar Castañeda?” - Entre risas-.

\section{E: ¿Y has trabajado temas de pareja en tu terapia?}

S: Por ejemplo, cuando estaba con mi terapeuta paso todo este tema de Mario, y pasó también que conocí a Álvaro. Entonces, fueron unos meses medio en incertidumbre porque no sabía qué hacer con mi vida. Bueno, no con mi vida, sino con mi situación amorosa. Y además tenía el internado, tenía la tesis, tenía a Mario, y tenía a Álvaro. Pero por lo mismo de el corte psicodinámico que es mi terapia, ella nunca me decía nada, cómo qué hacer, o que anote mis pensamientos, emociones, conductas, cero esas cosas. Sino más bien me ayudaba a pensar, a reflexionar, como lo que hacemos ahorita, ¿no? Pensar, reflexionar, aterrizar ciertas ideas, emociones, o ciertas actitudes o energías que yo identifico, y hacia donde quiero dirigirlas. 


\section{E: Entiendo... Última pregunta Sofía, ¿Qué es elección de pareja para ti?}

S: ¿Qué es elección de pareja para mí? - Suspira-. Bueno, para mí lo puedo ver desde dos ángulos: por un lado, es encontrar a la persona con la que me pueda sentir segura, tranquila, libre, y por el lado de los dos, que yo pueda encontrar que la otra persona también se sienta segura, tranquila y libre.

\section{Participante 6: Rodrigo}

E: Rodrigo, cuéntame: ¿Cuántos años tienes?

R: Tengo 25 años

$\mathrm{E}:$ ¿Cuándo te recibiste?

R: Me gradué en el 2015, y me licencie en diciembre de ese mismo año.

\section{E: Actualmente, ¿trabajas?}

R: Sí, en un colegio privado de Lima. Hice mis prácticas ahí haciendo acompañamiento terapéutico. Es un colegio bastante personalizado, ósea de educación personalizada, y trata de ver al alumno de modo individual, profundizar si es que lo demanda, y en base a su historia. Entonces es vacan no agrupar en base a un salón de clases, sino en base a que puede ser un niño con alguna particularidad, o porque podría estar atravesando por alguna problemática la cual se trata de atender, y sobre todo de identificar a tiempo. Me gusta cuando se le dedica un tiempo, el acompañar a el niño, que sobre todo se encuentra, dependiendo del grado, atravesando por diversas problemáticas, que para mí el colegio asume de alguna manera la debida responsabilidad y compromiso con este, entonces eso lo hace uno bueno.

\section{$\mathrm{E}:$ ¿Te interesa la psicoterapia?}

R: Sí, claro. En el colegio si bien soy un acompañante terapéutico, también realizo un tipo de terapia breve si es que el niño lo necesita. Y es bacán, porque conoces cómo el niño se desarrolla dentro del aula, pero al mismo tiempo su lado más vulnerable en el espacio que se propia fuera de esta, lo ves de manera más evidente en casos de bullys agresores, que a mi parecer son quienes necesitan de más apoyo, porque internamente llevan consigo mucha carga. En este momento me gusta formar parte de esta identidad, en donde siento que el poder apoyar a niños, familias que se están formando, que muchas veces necesitan de orientación, es realmente gratificante cuando todo sale bien. Pero, en un futuro si me gustaría tener un espacio en donde pueda hacer terapia. 


\section{E: Cuéntame un poco sobre ti, sobre tu infancia.}

R: Los mejores recuerdos definitivamente. Mi papá es profesor de historia, siento que su manera de contarla, como tal, coincide directamente como el ser humano que es espontáneo, divertido. De hecho fue mi profesor en la universidad, fue retador para ambos, pero me sentía orgulloso de ser hijo de alguien tan culto, objetivo, divertido, que sobre todo era muy querido y reconocido por otros. Cierto, también tiene un taller de carros que ha sabido llevar adelante, de hecho acaba de abrir el segundo en la mar, y mantiene una larga lista de clientes desde el año ufff. Mi mamá... Mi mamá es ama de casa, es la típica mamá que cuando llegas a la casa después de un largo día va a estar ahí esperándote con una sonrisa y queriendo engreír con un plato de comida. Mamá engeridora, que está ahí supervisando que todo esté bien, porque también busca tener el control en casa, y algo intrusiva por saber que todo realmente está bien en la vida de su hijo, y ya ni te cuento con su esposo (entre risas). Otro aspecto es que es exigente. Me decía que yo podía dar un más en cuanto a notas. Yo era un alumno bueno, ósea entre 16,17 , por ahí un 18 , pero mi mamá decía que me exigía porque sabía que yo podía más, que sino no no me exigiría de esa manera. Entonces me quede con esa idea en que siempre se puede hacer un poco más, la exigencia. Bueno, me desvíe un poco, entonces si bien es ama de casa, siempre ha estado involucrada en el tema gerencial en el taller, entonces eso también la hace estar comprometido no solo en la casa, sino es el seguimiento constante que hace. Es recontra sociable, creo que tiene más planes que yo lo fines de semana (risas). Me acuerdo mucho de los viajes que hicimos los tres, cuando yo era más pequeño, el primero fue a Orlando, para un niño de 10 años era el lugar más espectacular en donde quería estar. Posteriormente viajamos más por el Perú, mi papá decía que quien no conoce a su país, no conoce a su patria, así que comenzamos por Cusco, Arequipa, Piura, Cajamarca, Puno, Iquitos, Trujillo, creo que no me olvido de nada, esto ha sido a lo largo de mi adolescencia. Ya de ahí he viajado a río, buenos aires por un intercambio, y algunas veces a estados unidos.

\section{E: ¿Y cómo son tus papás como pareja?}

R: Ya tienen como 30 años de casados. A mi mamá le costó muchísimo tenerme, no es que era estéril, pero no sé, a veces pasa y no salía embarazada. Más allá de la adversidad, ella valoraba muchísimo, el apoyo que tenía de mi papa, porque le decía "chola, acá estoy yo contigo, no tienes que preocuparte de nada", y que esas palabras la hacían a ella calmarse, porque era más la presión que ella se ponía de buscar ser madre, que la situación en sí. Entonces, creo que lo que siempre he visto en ellos en el apoyo. 
Mi mamá ahora apoya a mi papá en los talleres que tiene, porque la verdadera pasión que él tiene es dictar, ser profesor, y lo hace en dos universidades y un colegio. Mi mamá se encarga de los pagos a proveedores, de solicitar repuestos, accesorios, de cobrar, y lo hace muy bien. Y sé que mi papá siempre le agradece en el manejo que tiene en la logística. El tema de ser agradecidos el uno con el otro, o el de felicitarlo cuando alguno obtiene alguna gratificación, entonces son un equipo de apoyo total.

\section{E: ¿Y tú, cómo eliges a tu pareja?}

R: Es todo un proceso desde que conoces a la persona, no sé... y son procesos distintos. Pero siempre ha sido en circunstancias sociales, una especie de química al inicio, una buena conversación, donde cada uno muestra cualidades bonitas de cada uno, lo que tiene que lo hace genuino, auténtico. Y ello da pie a seguir contacto, viendo a esa persona con la que podría formarse algo. Que es como una especie de elección mutua en primera instancia, en donde deciden continuar viéndose por periodos prolongados, hasta sentir que realmente quieres comprometerte con ella, y ella contigo.

\section{E: ¿Qué aspectos conscientes consideras al momento de elegir una pareja?}

R: Que sea conversadora, que sea divertida, que pueda hablar de distintos temas. No significa que sea histriónica y que haga payasada y media, pero sí que tenga humor y que también tenga momentos serios. La honestidad también es muy importante, que pueda ser auténtica y que ello no se vea forzoso, sino más bien natural, porque hoy en día siento que las personas a veces tratan de aparentar o calzar en base a la persona que tienen al frente y eso se nota, entonces no es la idea. Que sea también alguien que tenga temple para afrontar las cosas, asertiva. Y en cuanto al físico no tengo un tipo definido, pero no me gustan las chicas muy altas, de hecho las tres parejas serias que he tenido han sido pequeñas.

\section{E: ¿Identificaste algún patrón en estas elecciones que mencionas?}

R: Quizás por el lado que mis últimas tres enamoradas siempre en momentos como de tensión o frustración, siempre me he sentido que soy yo el que tiene que contenerlas. (...) Casi que por momentos he hecho cosas de psicólogo con ellas, yo como contendor de ellas porque lo necesitaban. Asumo que yo también quería ser contenido, pero a veces esto no se daba, por el tema de que las priorizaba a ellas, o las demandas de estas eran más "complejas", entonces si me dejaba de lado en algunos momentos.

\section{E: ¿Has identificado aspectos inconscientes con tu terapeuta respecto de tus elecciones?}


R: Un aspecto consciente, que fue inconsciente en un primer momento fue el ser contenido. Me pasó con una alemana a la que conocí cuando hice mi intercambio en río, y posteriormente tuvimos una relación a distancia. Por el lado de mi mamá, aprendí que la exigencia que tengo conmigo mismo casi en un sentido punitivo, me castigaba cuando alga salía mal, y mi madre es una persona súper exigente con nosotros. Entonces, creo que soy bien exigente con lo que busco, analizar antes de lanzarme. Hay veces en las que sobre pienso demasiado algo, y al final la cago de tanto hacerlo, aparte la cabeza marea, te agotas mentalmente, pero siendo así y adicional psicólogo, peor ¿no? A veces eso nos puede jugar una mala pasada, pero pero descubrí que también mi mamá siempre buscó protegernos, sobre todo a mí. Acuérdate que yo le coste años de buscarme, entonces tiene sentido. Ella decía: “Antes de que tú llores, ya te daba la leche..." Se anticipaba porque ya sabía lo que necesitaba. Quizás viene por ahí. Y de hecho como te comente, ella lucho por tenerme, entonces me hace mucho sentido esto último que te comento.

\section{E: ¿Qué similitudes encuentras con tú padre o madre o algún referente en tu familia en cuánto a las parejas que has tenido?}

$\mathrm{R}$ : La relación de mis padres es un modelo de relación. Yo desearía poder tener una relación de pareja como ellos tienen. Se aceptan como son, con sus virtudes y defectos. Entonces, por ejemplo, la seguridad que muestra mi mamá la busco en una pareja porque a mí me da seguridad. Pero al mismo tiempo, no busco una pareja que me controle o que sea intrusiva como también es mi mamá, porque me termina agotando. Mi papá es el bonachón, el que apoya, el que adormece, el que a veces puede quedarse en el rol de "chonguero", y que mi mamá a veces lo frene, más en cuanto a relación, porque como padre eso es divertido, en relación ya es cosa de dos. Pero hablando en general hacen un excelente equipo juntos, han sabido adherirse uno al otro, diciéndose las cosas cuando han debido decírselas, sin faltar al otro, si no escuchando y respetando, dos puntos casi tácitos que se esperan en una relación de pareja, per tan escasos a veces.

\section{E: Y para terminar Rodrigo, ¿qué es elección de pareja para ti?}

R: Hay varias posturas, desde el punto de vista más consciente uno puede escoger una pareja, finalmente tienes poder de decisión. Pero a veces cuando realmente te enamoras, eso no se escoge. Lo que escoges es seguir vinculándote con ella. Y escoger a una pareja, es escoger desde un inicio a alguien cuyos atributos rescatas porque te hacen sentir bien, tú mismo, cómodo... Y eso lo sientes. Los procesos son diversos, pero finalmente uno elige con quien quiere estar. 


\section{Participante 7: Federico}

\section{E: Federico, cuéntame un poco sobre ti.}

F: Bueno, como te dije tengo 24 años, soy psicólogo clínico, de hecho termine la carrera en julio del 2015 en la cato, y justo hace unos días atrás me titule. Ahora ando trabajando.

\section{E: ¿En qué trabajas?}

F: Yo hice mí internado en epicentro, es un centro bien bacán, en realidad es el único que brinda un servicio de salud sexual para la comunidad gay y trans, y me quede por un tiempo chambeando después de que acabe mi internado. De hecho ahí aprendí un montón en técnicas de terapia de pareja, consejería, para esta población que de hecho es la que más ayuda necesita, creo... Y bueno actualmente me encuentro en la compañía de teatro, circo y música realizando acompañamiento terapéutico.

\section{$\mathrm{E}:$ ¿Te interesa la psicoterapia?}

F: Sí, de hecho todo psicólogo clínico piensa a mediano - largo plazo en tener un consultorio y atender, pero para eso falta mucho (entre risas), poco a poco uno construye su futuro, pero para eso hay que ilustrarse y mucho. Lo bueno es que de cada trabajo se aprende y mucho. Ves gente, y trabajas con gente, y para gente, es interesante, y de hecho sigues creciendo.

\section{E: Cuéntame un poco sobre ti}

F: Aparte de la psicología, siempre me ha gustado la actuación. De hecho en el colegio, siempre actué en diversas obras, y en la actualidad no cierro las puertas de hacerlo, pero ahora estoy metido en lo que es mi profesión, el aspecto de servir a otro. Algo que me interesa mucho es viajar. Irte solo, explorar nuevos lugares, costumbres, nuevos paisajes. Siempre es bueno irte y regresar, porque regresas distinto, menos cargado, más libre y conoces mucha gente con la que hablas, diversas perspectivas, miradas, creo que nunca dejas de conocer y descubrir, es un gran aprendizaje. De niño viajaba con mi familia, ahora de grande uno viaja solo, va construyendo su camino.

\section{E: ¿Y cómo es tu familia? Cuéntame un poco sobre tu infancia}

F: Mmm, que te cuento. Tengo una hermana, Úrsula. Es muy parecida a mí, en el sentido de que también es liberal, podemos conversar de todo, fumar "weed" juntos. Ella es 4 años mayor que yo y nunca se ha sentido esa diferencia. Ella fue a un colegio de mujeres y yo a uno mixto, pero es chévere porque no es la típica mujer de un colegio de solo mujeres, sino todo lo contrario, como te digo es liberal, es comunicadora, es buena onda. De hecho ella fue la primera en saber sobre mi opción sexual y siempre me 
acepto. Con ella me he metido unas bombas, conversaciones, la he pasado muy bien con ella, es una persona que siempre ha estado en mi vida. Mi madre, con ella tengo muchísima confianza, con mi papá no tanto. Ósea, eso no quiere decir que no la tengo con mi papá, sólo que es por afinación, creo, tenía más acercamiento con mi hermana, y yo con mi mamá. Pero siento que siempre nos hemos llevado bien, de hecho. Mi papá es el bromista, mi mamá también pero no tanto. Ella es la que se preocupa por saber cómo estas, la que si necesitas algo ella siempre va a estar, ella es recontra servicial, mi papá trata de hacerte reír o hacerte sentir bien con algo "random", divertido para él, pero se queda ahí y esas cosas. De hecho mi mamá fue la que me ayudo a asumirme, a aceptarme como soy. Bueno, ella ya se había dado cuenta, cuando se lo dije, hace unos cuatro años atrás, ella me dijo que ya lo sabía. Mi papá, creo que ya lo sabe, pero nunca hablamos de eso. Mi mamá no dudo ni un segundo en apoyarme. Lógico, el primer momento siempre es un proceso de entender, muy a pesar de que ella ya era consciente de que su hijo era gay, es distinto a escucharlo, a que él te lo diga, a saberlo por él. Entonces, como te digo, siempre han sido distintos, pero juntos... No sé, es loco hablar de ellos, porque están separados, sin estarlo tanto.

\section{E: ¿A qué te refieres "el estar separados, sin estarlo tanto"?}

F: Es que mis papás se llevan muy bien, de hecho se separaron hace un par de años, no están divorciados, pero hasta ahorita separados se van al cine y todo, pero espero no tener una relación como la de ellos... De que se conocen se conocen, de que se llevan bien se llevan bien, pero no sé, como te dije mi mamá es bastante servicial, y mi papá es bien flojo, como que esas relaciones del hombre no limpia, no lava, no hace nada, pero se va al chiste, al juego, ojo también porque eso se lo permitía mi mamá... y si así funcionan, así funcionan y no me voy a meter, pero eso es algo que yo no quiero para mí. Ósea, mi flaco está condenando a cocinarme toda la vida porque es el chef, pero ósea yo lavo, yo limpio, hago algo. No hay que llevársela tan fácil tampoco... son dos.

\section{E: Cuéntame un poco sobre tu pareja.}

F: Él es chef, llevamos un año juntos de relación, de hecho es mi segunda pareja. Es bien raro, porque pensamos bastante igual en muchas cosas, los dos somos bastante tranquilos, no relajados. Nos gustan las mismas cosas, no salimos mucho a fiestas, sino somos más de "netflix", confiamos bastante el uno en el otro. Que es lo que pasa, yo siempre he pensado que uno debe confiar a ojo cerrado en el otro, y como los dos pensamos así, los dos pensamos ciegamente en el otro, tenemos la misma forma de tomar la relación: en pareja. Nosotros no es que tengamos una relación abierta, nosotros 
creemos, yo personalmente creo que solo me puedo enamorar de una sola persona, pero nosotros somos abiertos de alguna manera sexualmente, en el sentido que cada uno puede estar con alguna otra persona. Aún no lo hemos hecho, pero lo hemos hablado y “fresh". Ósea no lo hemos hecho porque ahorita no nos provoca...Pero si a él le provoca en ese momento lo hablamos y ya vemos, y yo igual. Yo lo amo, lo quiero y estoy feliz, yo aún no quiero encontrar a la persona definitiva, tengo 24 años, quiero conocer, por eso me gusta estar con él, porque digo putamadre quiero conocer más gente todavía, tengo un mundo por recorrer, y él piensa igual, más o menos igual que yo.

\section{E: ¿Es como si ambos ideales o planes de vida estuvieran de acorde en ambos, es como un condicional cuando buscas una pareja?}

F: Sí, es que de hecho es importante. Aparte con mi primer enamorado, fue un caos. Lo he pensado un poco, pero entre una y una pareja, he estado sólo un tiempo. Primero porque me demoré un montón en terminar \{la relación\}, como un año más o menos, y después estuve como dos años solo, descubriendo el mundo, qué sé yo. Y me pasaba de vueltas, porque yo sentía que en ese momento estaba buscando, y no encontraba, y seguía buscando lo mismo que ya había tenido en la primera relación... Me fui de viaje, como mes y medio por Perú, Bolivia, Argentina y Chile, de mochilero, viajando solo, y ahí conversando con gente, de otros países, con todo el mundo, al fin y al cabo me di cuenta en verdad quizás no es que uno busque algo, es más o menos como que uno camina y se enamora digamos, ¿no? Porque yo he buscado otras cosas, supongo, pero estoy totalmente feliz. $\{\ldots\}$ Antes no estaba muy seguro, porque como te dije, mi primera relación fue muy caótica. Fue muy caótica y fue la primera, de hecho fueron 3 años. Lo conocí en una obra, pero él está muy "enclosetado", como muy muy “enclosetado". Y más aún, a mí me decía que no era gay el "brother”. Para el yo sí fui

su primer todo, porque según él, él siempre fue heterosexual, pero mentira pues. Él es una persona muy "enclosetada", es del medio, es famoso, es conocido, y fue muy caótico, nos peleábamos todo el día, nos veíamos y nos peleábamos. Y ahí yo me di cuenta que no quería eso, esconderme. $\{\ldots\}$

\section{E: ¿Cómo así esconderte?}

F: No sé, ir a un restaurante y que él entre primero para ver si conocía alguien y después entrar. Al principio no me importaba porque no me daba cuenta, estaba un poco sesgado. Hasta que un buen día terminados para bien, porque ya habíamos terminado unas cuantas veces, y fue bastante difícil, y no sabía como qué esperar de lo siguiente, porque en verdad estar en una relación, en donde me escondía, y creo que lo que él 
buscaba era eso, esconderme. Y yo, lo que busco ahora yo es no esconderme. Ojo yo no lo odio, yo lo quiero, ósea ya no lo amo, pero lo veo y lo abrazo, lo quiero, él es recontra divertido. Lo que paso fue que pasaron tres años de relación y nadie sabía, ni sus amigos que él estaba conmigo, ni uno. Y ahora yo me doy cuenta y digo "que huevón fui" obvio en ese momento no eres consciente de nada... Estaba bastante enamorado, por eso me demoré bastante en terminar. Entiendo que hay gente homofóbica, y los taxis, la sociedad y qué sé yo, pero el que no le haya contado a ni un solo amigo, creo que eso es un poco grave... Y yo lo permití. Igual creo que él tiene un montón de "issues" que tiene que resolver, porque después de mí volvió con su ex mujer. Que pendejo... Pero bueno, es su decisión... Yo no lo iba a sacar del closet, eso es chamba de él.

\section{E: ¿Y qué te gustaba de él?}

F: Su inteligencia, que fuese muy divertido, también me gustaba que fuese talentoso, porque canta, baila, y ahora se dedica a pleno a la actuación. Creo que también quiere incursionar en el tema de dirigir, tiene mucha pasión en lo que hace y en lo que desea hacer en el tema de su chamba, como actor, en sus planes, en eso sí. De hecho me quería bastante, me hacía sentir muy querido porque me cuidaba bastante, ósea yo también a él, pero también dentro de lo que yo podía (silencio) ... bueno dentro de lo que él me permitía. Siempre que lo necesite de verdad, siempre estuvo ahí para mí. En ese aspecto siempre estuvo como que conteniendo, y viceversa... Sí, siempre nos cuidábamos.

\section{E: ¿Cómo así cuidar?}

F: Ósea de contenernos, de abrirnos, de conversar de todo, si es que yo estaba mal o necesitaba desahogarme con alguien, él siempre estuvo ahí, pero hablando de ello, siempre eran aspectos íntimos, que no se muestran, que están guardados, que son privados, y no es que este mal, pero volvemos a la idea de esconder.

\section{E: ¿Identificas aspectos en común, patrones, en tu primera relación con la actual?}

F: No alucina, son bien diferentes... uno es artista y el otro no. El otro es deportista y el otro no. Ósea Gabriel mi primer enamorado chupa todos los días, no sé, yo no puedo con eso, con ese estilo de vida. En cambio el actual nunca sale, quiere dormir, chorrear, ir al malecón, igual que yo. Ni si quiera se parecen, ni física ni psicológicamente.

E: Entonces de manera consciente, ¿qué aspectos consideras en tu elección de pareja? F: Mmm... No se la verdad... Quizás uno no busque algo, no es que camines por ahí y encuentres, simplemente sale, porque cuando buscaba algunas cosas, pasaban otras. Me gusta que se lleve bien con mis amigos, con mi mamá, con mi hermana. En cambio con 
el otro, nadie lo conocía, bueno él tampoco se dejaba conocer, mi mejor amiga sólo lo vio dos veces, con eso te digo todo. Que las personas que yo quiero puedan conocer a mi pareja, porque finalmente es mi pareja, no es mi amigo, no es mi "brother", es mi pareja. Mi chico ideal es como el que tengo ahorita $\{$ pareja actual\}, sabe lo que quiere, chambea, tranquilo, no me oculta, no lo oculto, no tengo ningún problema. Creo que ese aspecto es importante, al menos para mí.

\section{E: Entonces dirías que un aspecto fundamental en tu elección de pareja es el "no esconderte".}

F: Sí, obvio. Ya no quiero pasar por ese tipo de cosas, ósea permitir que alguien te oculte y por tanto tiempo, creo que no está bien. Entiendo que cada quien tiene un proceso distinto de asumirse, pero no es la idea que tu pareja pase por eso mismo también.

\section{E: ¿Y qué aspectos inconscientes has identificado en cuanto a tu elección de pareja?}

F: Lo discutí en terapia, yo quería buscar algo que sintiese la misma ilusión como de la primera relación, pero en ese momento no me había dado cuenta que eso se había perdido hace ya mucho tiempo, porque yo salí de la relación sin darme cuenta de eso... Porque yo definitivamente permití muchas cosas por cariño, porque lo amaba, pero creo que me olvide de mí, ósea ¿dónde quedaba yo? Nadie sabía de mí, nuestra relación casi que no existió, o no al menos para él, no lo sé... Y nada, creo que cuando deje de estar con él entendí que buscaba algo diferente... Ya no volver a eso, transformarlo. También me di cuenta que la química sexual no es indispensable, pero es importante, yo tuve salientes, sí... Y con un saliente que me impresionó por cómo era, era un chico súper interesante, entrador, inteligente, fluía demasiado bien, pero la química sexual... Desde cómo me daba un beso, terminaba con baba por acá y era como que no. Te corta todo lo que puedes estar sintiendo, el momento, el espacio, entonces a veces dejamos cosas inconclusas, y de ahí les damos un sentido, las transformamos.

\section{E: ¿Cómo así se transforman?}

F: Ósea de hecho yo no era consciente de muchas cosas que permitía en primera relación, de hecho era mi primera relación gay, de hecho me moría por él, yo fui su primer todo, entonces creo que todo ello permitía cosas que no las podía ver, pero que en terapia, lógico, pude darles un sentido. 


\section{E: Para finalizar, Federico, ¿Qué es elección de pareja para ti?}

F: La elección de pareja... Pucha uno no elige, uno es totalmente diferente al otro. Uno camina donde está la bioferia de barranco y "pum", se enamora ¿me entiendes? No es que elijo, particularmente, no sé si es válido decir eso. Nos gastaría, creo, poder elegir, el hacer un "checklist" de ya, me gusta esto, me gusta esto, esto, pero no, no funciona así. Si el día de mañana termino con el chico con el que estoy ahorita, probablemente qué me dice si la persona siguiente con la que este sea la más “juerguera” y economista en un banco, pero lo quiero. Y claro, la personalidad atrae.

\section{Participante 8: Alexandra}

\section{E: Cuéntame Alexandra, ¿Cuántos años tienes?}

A: 25 años

\section{E: ¿Cuándo terminaste tus estudios?}

A: Termine la carrera y el internado en diciembre del 2014, me gradué en el 2015

\section{$E:$ ¿Y actualmente en qué te desempeñas?}

A: Siempre me llamo la atención la rama artística de la psicología, como es el TAE, que no se limita en cuánto a terapia exclusivamente, sino que va a otros contextos como educativos, empresariales, de generar un impacto social. El espacio en contanste movimiento, teatro, actuación, baile, todo ese tipo de representaciones visuales que nos genera esta rama, que detrás está el arte.

\section{E: ¿Estás trabajando actualmente ahí?}

A: Recién he comenzado la formación en terapia de artes expresivas, estoy muy emocionada, era algo que quería hacer hace muchísimo tiempo, pero lo pospuse hasta que dije: ;es ahora o nunca! Voy a poder llevador a terapia individual, como a contextos colectivos como te comente, entonces es trabajar en conjunto, de hecho nuestra labor es el servir, y que mejor que llevarlo no sólo al espacio conocido de sanación, terapéutico, si no a espacios en donde a veces esto no llega y sobre todo con un enfoque distinto, porque si bien este movimiento cada vez se hace más conocido, en el Perú recién está comenzando a desarrollarse.

\section{E: ¿Cómo así llegaste a interesarte por esta rama?}

A: Un profesor capazo que tuve en la universidad me introdujo de alguna forma, aparte siempre he sentido que soy una persona que a veces le cuesta conectarse con algo, hablando de manera en general, entonces siento que mediante un estímulo $\mathrm{u}$ otra 
conexión, puedes generar otras comprensiones. Es otro proceso, pero consiguiendo o logrando los mismos resultados.

\section{E: Cuéntame un poco sobre ti, sobre tu infancia}

A: Sobre mi infancia bien, pero complicada, como toda relación madre e hija, mi mamá es una persona bien controladora, pero en realidad ya pase por mi momento de odio a mi mamá, y ya estamos en un proceso mucho mejor. Es súper controladora en el sentido de que es la mamá que me llama toda la noche cuando salgo. El tema de las salidas a sido bastante difícil, la hora límite, preocupaciones si me demoraba en responder un mensaje, una llamada, y en todo sentido siempre trata de influenciar en todas mis decisiones. No como un consejo, sino infiriendo que haga eso, queriendo ejercer el control. La relación mejoró, sí, de hecho he estado en terapia 5 años, entonces definitivamente ya he pasado por todo un proceso de aprender a aceptar, a lidiar con sus comentarios, control, con mi papá también. A pesar de que sigo viviendo con ellos, ya todo se está acomodando. No significa que no pelee con ella, ni que quiera controlarlo, sino más de aceptarnos como somos, ellos son mi familia. Con mi papá igual, aunque somos muy parecidos, entonces chocamos mucho: los dos somos igual de tercos, y terqueamos juntos y chocamos. Entonces definitivamente también hemos pasado por momentos de odio, nuevamente creo que mi terapia ha ayudado en aceptar a ambos como son, botar la rabia, de hecho con mi papá son más las cosas que nos unen que las que nos separan. Él es loco salud, sobre todo con la comida, entonces mi papá fue vegetariano, bueno desde que yo soy vegetariana, el de nuevo a intentado volver a serlo, de hecho eso nos une, a los dos nos gusta un montón la medicina alternativa, el curiosear con las nuevas tendencias, nuevos hábitos alimenticios, y ahora que vamos hablar de elección de pareja mi pareja es médico, de hecho hemos tenido problemas con eso porque yo detesto la medicina occidental, y bueno mi papá también piensa igual que yo.

\section{E: Cuéntame un poco más sobre tu pareja}

A: Él es médico. Es una persona muy buena, es muy terco, es temperamental, pero bastante genuino, una persona muy franca, que a veces en su franqueza puede ser muy directo, pero valoro porque sé lo muy sincero que es conmigo. Lo que me gusta es que ha dejado de fumar, y está actualmente en todo un proceso para mejorar sus hábitos alimenticios. Es una persona muy familiar, que realmente disfruta pasar tiempo con ellos, dedicado. Me gusta que sea sincero, dedicado, que siempre me hace reír. Me gusta las personas que somos cuando estamos juntos, me gusta que no me haga sentir distinta 
o me juzgue por pensar distinto a él. Me gusta que me ayude, que me acepte, que siempre busque formas de ayudarme en lo que pueda. Me gusta lo comprometido que es, en todo lo que hace se mete bastante. Es una persona estable que me da bastante seguridad. Tenemos muchas cosas que aprender el uno del otro, porque también somos personas bastante distintas: él es bastante carnívoro, yo soy recontra vegetariana, yo soy más paranoica con algunas cosas, él es más relajado, por eso creo que cada uno debe aprender un poco más del otro.

\section{E: ¿Cómo dirías que eliges a tu pareja?}

A: Yo antes quería al chico caballeroso, que tocaba guitarra, que escriba poesía, que me diera rosas, esa era la lista que tenía antes, que fuese parecido a mí, hasta que me choqueé con la realidad. Con mi primera relación salimos 6 meses, me termino a los 4 días, y para mí yo era la culpable, porque él era "el chico perfecto". Logre entender que no debía buscar un chico perfecto, de lista, y buscar a alguien que no sea mi chico perfecto de lista, sino el que me haga sentir mejor... Y es lo más real. Lo otro era más una ilusión, porque creo que no me mostraba tanto como yo era, sino en base a lo que él quería para preservar lo "perfecto". Pero con los que salía al comienzo se mostraban súper interesados y de ahí desaparecían: Creo que todo el inconsciente que me movía a estos hombres que finalmente me iban a rechazar o iban a desaparecer, ese patrón de vínculo no se consolidaba, sino que se largaban. Tuve que llegar finalmente al chico que me "cago" en mi cara, para poder salir de eso.

E: Esto de no mostrar lo real para preservar lo "perfecto", y de ahí sentir el rechazo o que iban a desaparecer lo identificaste en estos salientes que mencionas, ¿con qué lo asocias, vinculas?

A: Esto de mis salientes, que siempre salíamos por un tiempo y luego desaparecían. Lo asociaba con que yo debía de haber hecho algo mal. Para mí ellos eran los de la lista perfecta, el hombre perfecto. Igual intercale entre príncipes azules y "cagados". Este patrón que posiblemente sea el rechazo, lo identifico con mi infancia, mi niñez... Mi mamá estaba deprimida, ansiosa, y mi papá abocado a ella todo el tiempo, probablemente tiene que ver con eso: Como una niña que se siente sola, rechazada, entonces en todo mí proceso es a lo que he llegado a deducir y me suena lógico.

\section{E: Y ahora ¿Qué aspectos conscientes consideras al momento de elegir una pareja?}

A: Antes me gustaba el estereotipo de chico perfecto para mí. En ese momento yo quería al príncipe azul... El caballeroso, que escriba poesía, que toque guitarra, que me lleve rosas, etc. Que tengamos cosas en común. Pero ya no busco eso. Ahora busco a 
alguien que me complemente. Igual esa lista ya no existe, no la tengo, respecto de qué quiero como pareja, pero busco a alguien como mi pareja actual. Porque nos complementamos bien, el cuidarnos el uno al otro que es muy importante para mí. El cuidado personal y el cuidado del otro. El ser un equipo y apoyarnos, que sea reciproco.

E: ¿Qué aspectos inconscientes has identificado con su terapeuta respecto de tus elecciones?

A: Bueno lo que te comente, que haya buscado este rechazo o el auto sabotear estos vínculos que formaba, el volver a conectarme con esa Alexandra niña, que se sentía sola, abandonada, y no juzgo a mi papá, él siempre estuvo para mí mamá, y debía cuidar de ella, pero a veces esa niña se sintió sola también, entonces creo que era la manera en la que yo había aprendido a vincularme. Una madre que le costaba conectarse con su hija, su única hija, porque estaba sometida a una depresión que no le permitía ver más allá, y que cuanto intento reparar esto, este control, vínculo, ya era un tiempo muy prolongado. Por eso hemos tenido esta relación odio, aceptación, porque al final siempre van a estar ahí, son parte de ti, y es aprender a lidiar vivir con ello.

E: Y en ese sentido, ¿encuentras similitudes con alguna de tus figuras parentales o algún referente en tu familia en cuánto a las parejas que has tenido?

A: Siempre pienso que yo soy como mi papá y miguel, mi pareja actual, como mi mamá, pero finalmente se complementan. Incluso cuando conversamos los 4 me doy cuenta que yo soy más como mi papá en cuanto a ideas, estos aspectos de la medicina alternativa, incluso quieras llamarlo estilo de vida, finalmente coincides en cuanto a visiones y mi mamá a miguel, preocupados, pendientes del otro, de cuidado. Sobre todo, cuidarnos el uno al otro, eso me gusta.

\section{E: Para finalizar Alexandra, ¿qué es elección de pareja para ti?}

A: Es elegir a la persona con la que vas a compartir tu vida: con la que vas a formar una familia, con la que vas a compartir tus mierdas y tus cosas lindas, y con quien vas a encontrar un equilibrio y el encuentro de verdad. 